Universidad de Lima

Facultad de Psicología

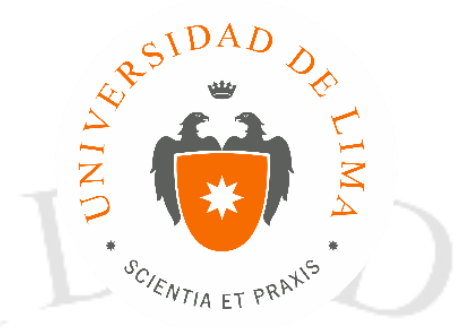

\title{
LA EXPERIENCIA DEL RETIRO EN DEPORTISTAS DE ALTA COMPETENCIA EN LIMA
}

Tesis para optar el título profesional de Licenciado en Psicología

\section{Paola Sofía Mendoza Llontop}

Código 20110779

\section{Asesor \\ Magaly Flores Giles}

\author{
Lima - Perú
}

Marzo de 2019 


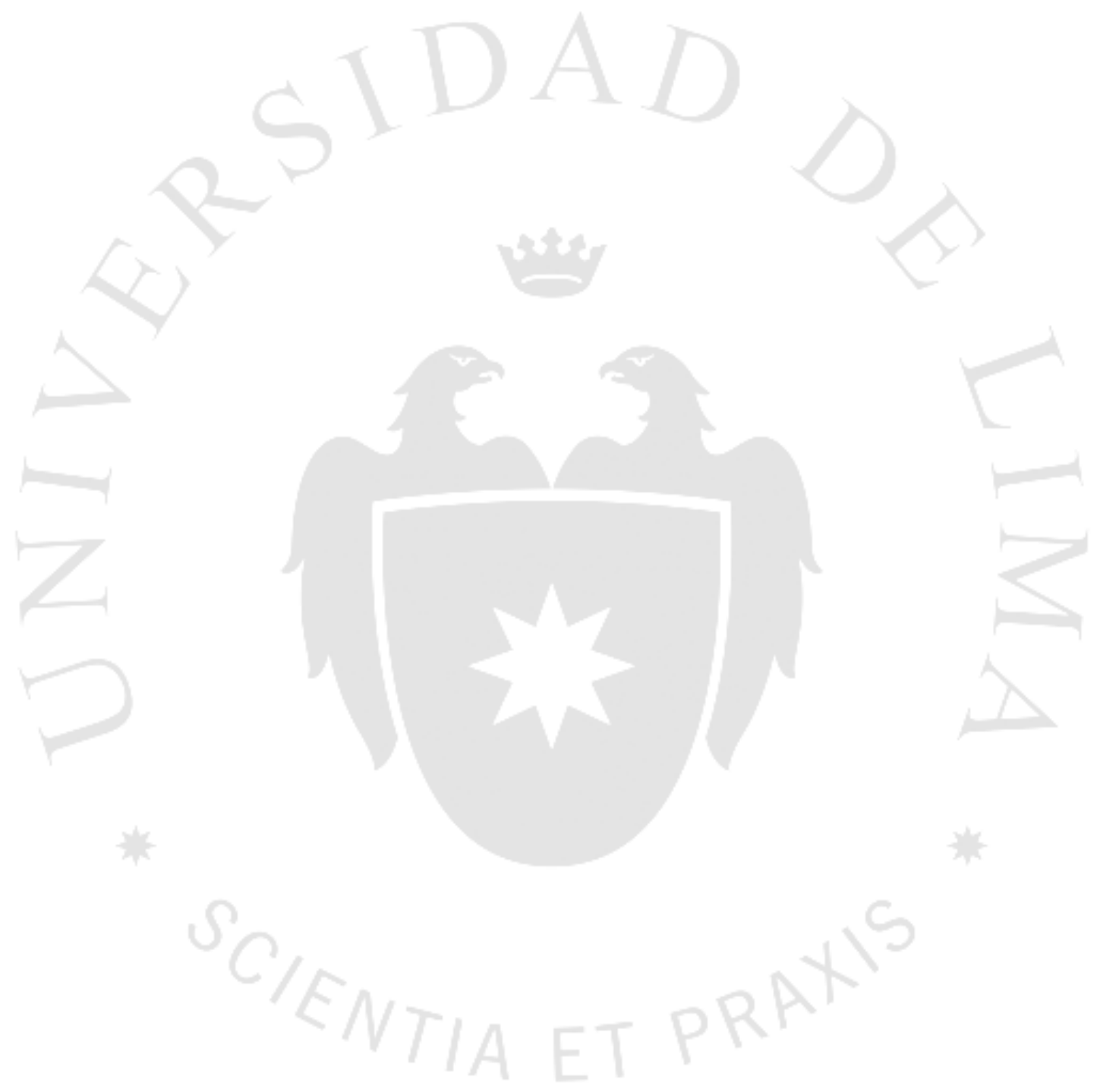




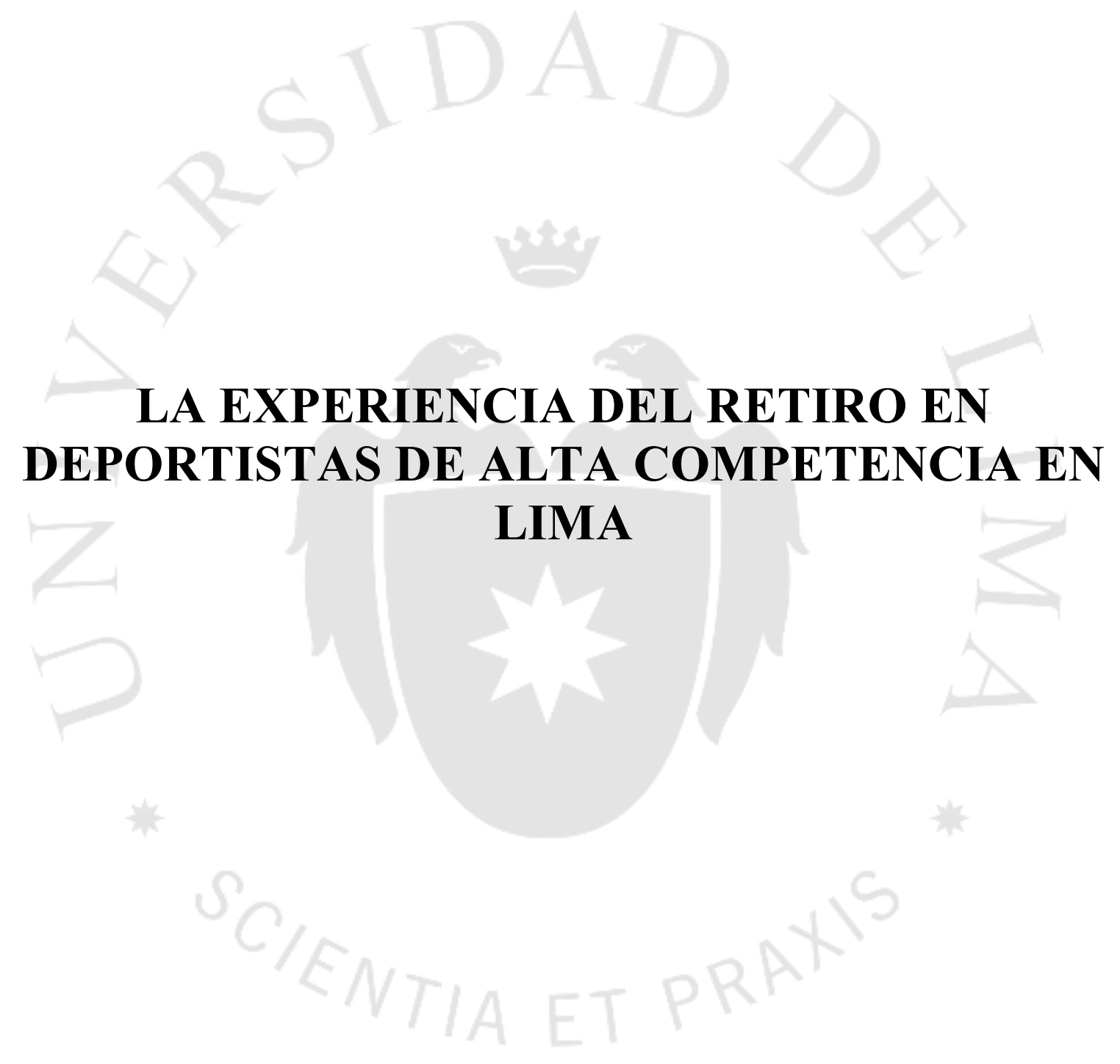




\section{AGRADECIMIENTOS}

Este trabajo no hubiese sido posible sin el apoyo de mis papás, mi hermana, amigos, asesora y profesores.

Agradezco especialmente a mis padres, Roxana y Guillermo, por incentivarme siempre valores como la constancia y el compromiso, así como me enseñaron a trabajar con perseverancia por mis objetivos y metas, sin ello esta investigación no hubiese alcanzado los resultados logrados. Gracias a mi papá por la inspiración, este tema novedoso nació de su curiosidad y pasión por el deporte y; gracias a mi mamá, por haber sido siempre la persona que me ha acompañado a lo largo de mi vida y ha estado presente en todos mis logros, apoyándome y empujándome a ser mejor. Asimismo, agradezco a Álvaro por las incontables horas que pasó junto a mí practicando, escuchando y alentándome, su apoyo me motivó a seguir esforzándome, siendo una pieza clave en la culminación de este trabajo.

Es a ustedes tres a quienes les dedico esta tesis junto con toda mi gratitud y amor.

Por otro lado, quisiera agradecer a mi asesora, Magaly Flores, por enseñarme que el éxito está en los pequeños detalles, sin su exigencia el trabajo final no sería el mismo.

Con mucho cariño, quiero agradecerle, también, a mi profesor Vicente Rodríguez, quien me apoyó incondicionalmente en todo el proceso, gracias por su paciencia y disposición para escucharme y ayudarme, su participación en la investigación ha sido muy importante para mí.

Por último, agradezco a cada uno de los deportistas que formaron parte de este estudio, no solo aportaron con información valiosa, sino que conocerlos y entrevistarlos ha sido una experiencia gratificante y de crecimiento personal. Estaré eternamente agradecida con ellos por su apertura a compartir conmigo sus vivencias personales. 


\section{TABLA DE CONTENIDO}

CAPÍTULO I: PLANTEAMIENTO DEL PROBLEMA.............................11

1.1. Descripción del problema...............................................11

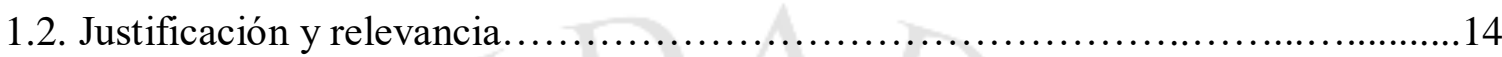

CAPÍTULO II: MARCO TEÓRICO ............................................... 17

2.1 El deporte................................................................. 17

2.1.1. El deporte de alta competición........................................18

2.2 El deportista de alta competición..........................................18

2.2.1. El desarrollo del deportista......................................20

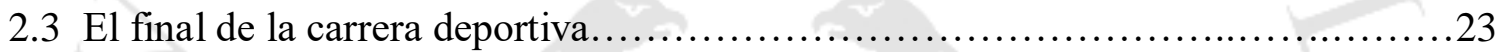

2.3.1. Causas del retiro.................................................. 24

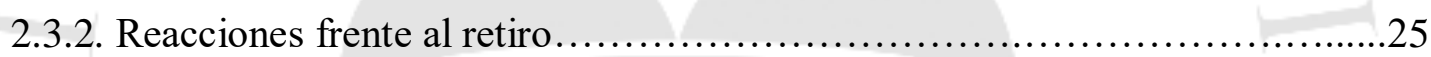

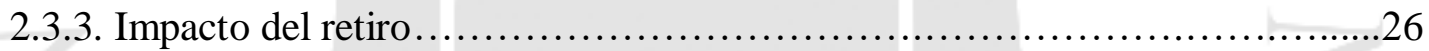

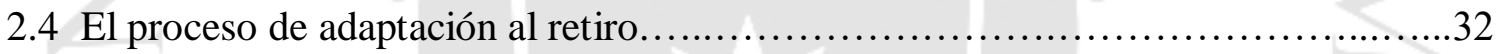

2.4.1. Recursos de Adaptación............................................... 35

2.4.2. Transición a una carrera profesional alternativa..........................43

2.5 Servicios tras la retirada...................................................44

2.5.1. Apoyo psicológico durante el retiro.................................45

2.5.2 Programa de asistencia de carrera. ...................................46

2.5.3 Estrategias de soporte a los deportistas.............................47

CAPÍTULO III: OBJETIVOS........................................... 50

CAPÍTULO IV: MÉTODOS................................................. 51

4.1 Tipo de investigación y método........................................... 51

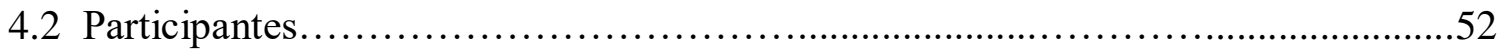

4.3 Técnicas de recolección de información.........................................

4.4 Procedimiento de recolección de información.................................54

4.5 Estrategias de análisis de información........................................55 
CAPÍTULO V: RESULTADOS Y DISCUSIÓN. 58

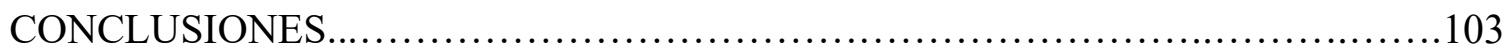

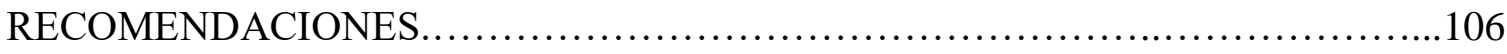

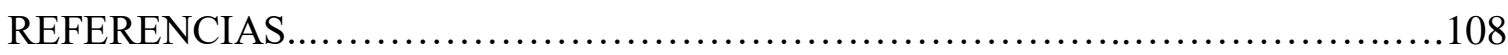

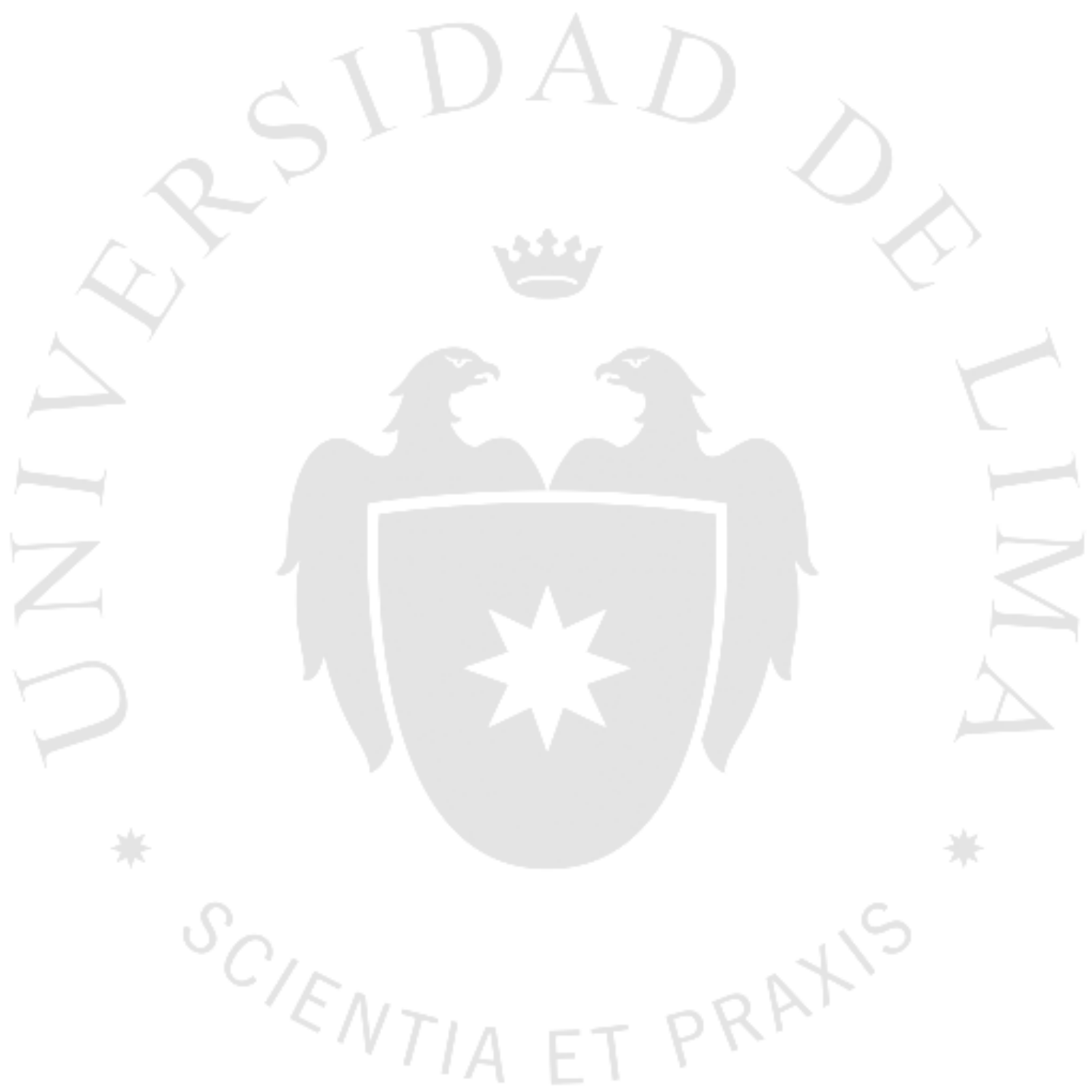




\section{INDICE DE TABLAS}

Tabla 4.1. Variables Sociodemográficas

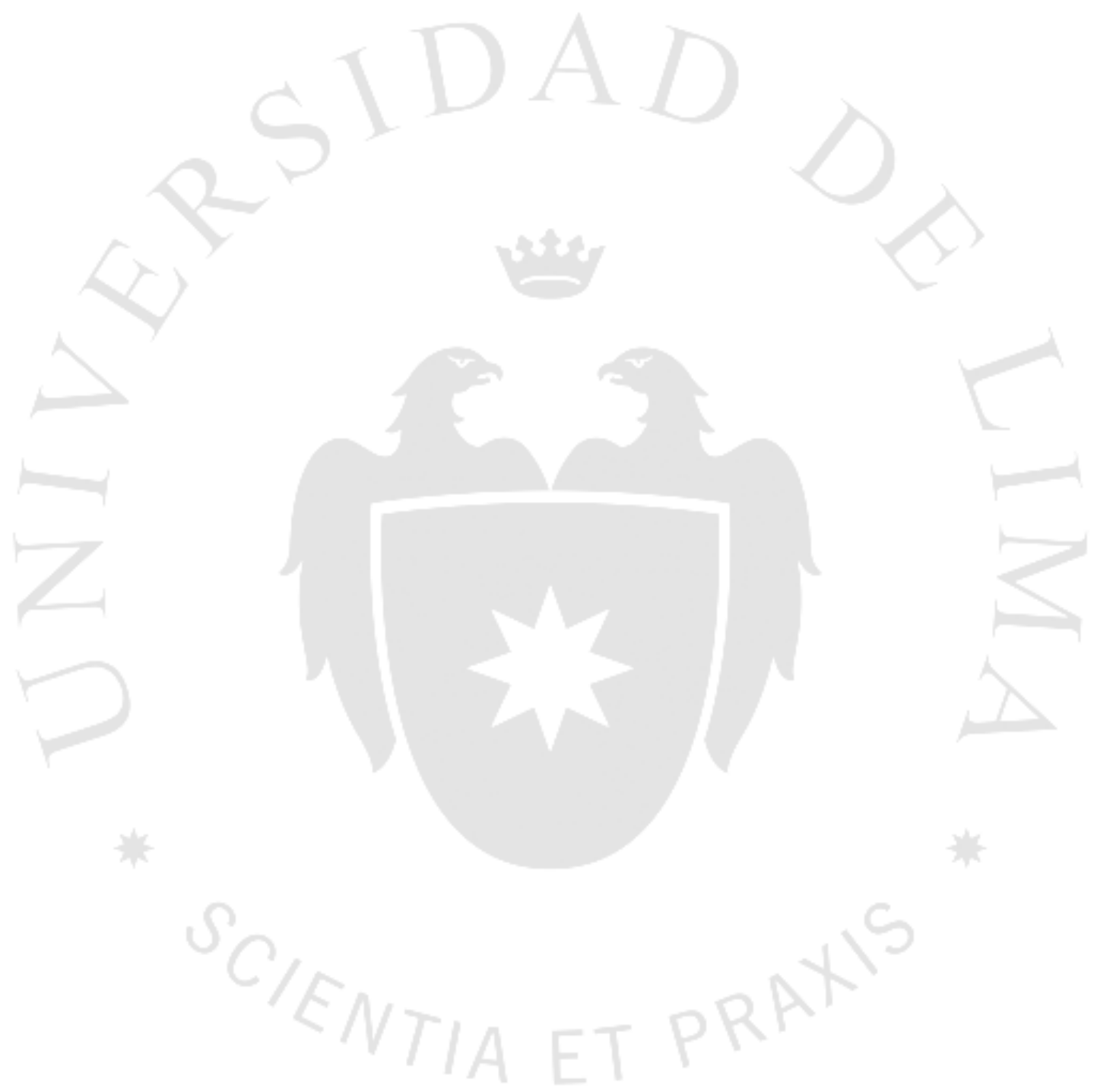




\section{INDICE DE FIGURAS}

Figura 2.1. (Modelo de desarrollo de la carrera deportiva) $\ldots \ldots \ldots \ldots \ldots \ldots \ldots \ldots \ldots \ldots \ldots .21$

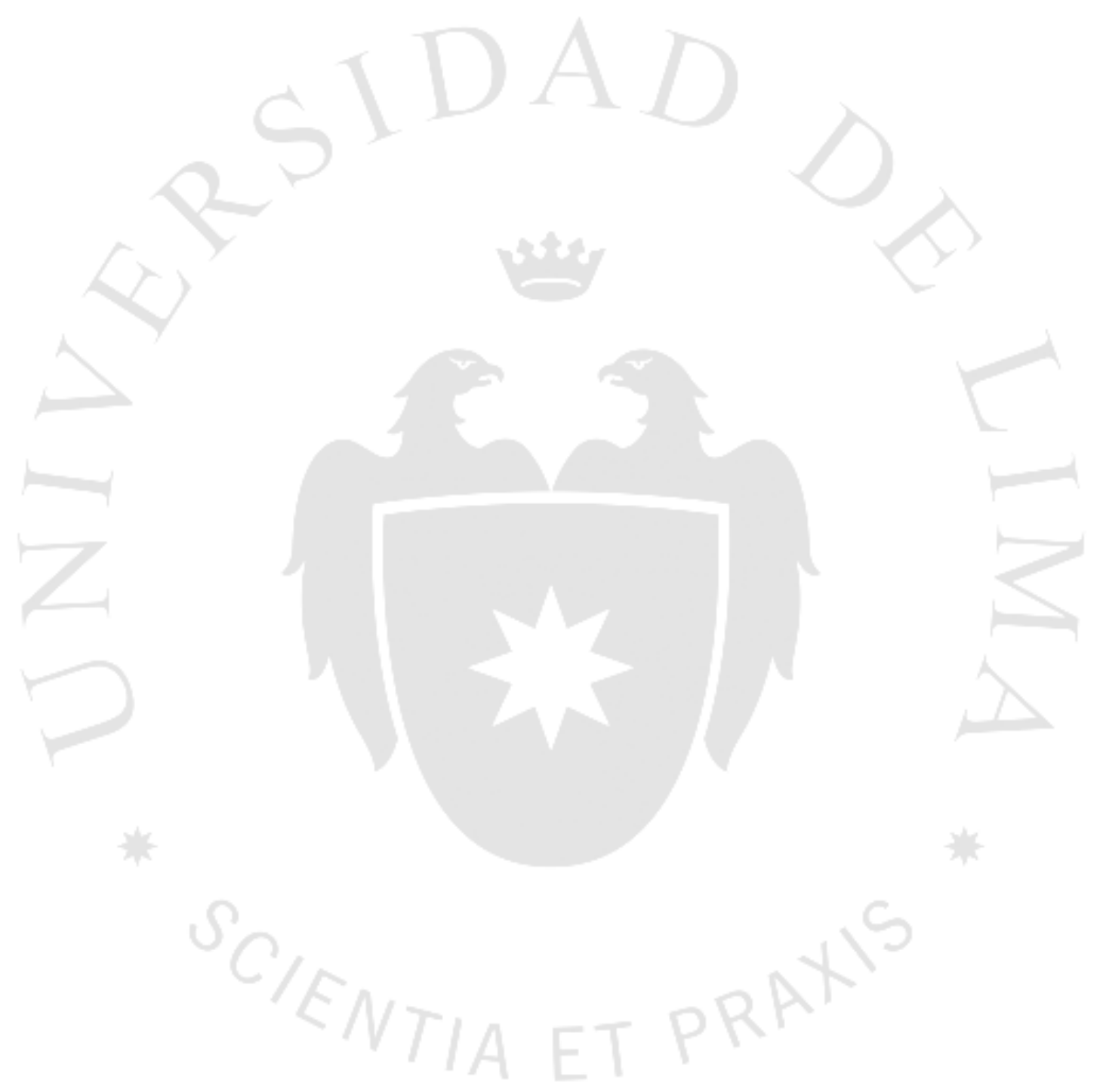




\section{INDICE DE APENDICES}

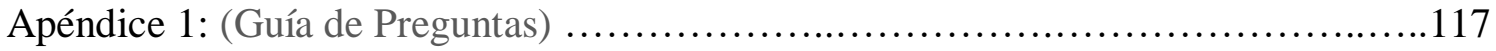

Apéndice 2: (Consentimiento Informado) ......................................119

Apéndice 3: (Cuestionario de Validación por Opinión de Expertos)...................121

Apéndice 4: (Sesión de credibilidad de los resultados)...............................129

Apéndice 5: (Ficha de datos personales) ...........................................139

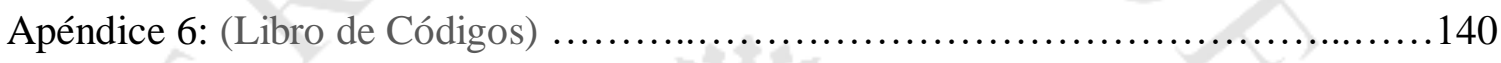

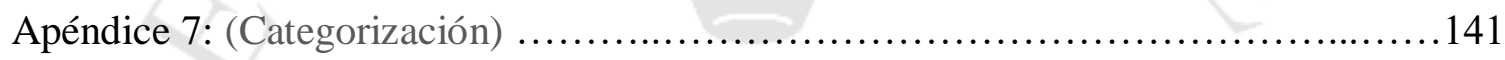




\section{RESUMEN}

La presente investigación busca conocer la experiencia de los deportistas de alto rendimiento al retirarse, en Lima. El estudio se desarrolló bajo una metodología cualitativa, de tipo exploratoria y descriptiva, utilizando un enfoque fenomenológico. Para recolectar la información, se utilizó una ficha de datos personales y se realizó una entrevista semiestructurada a diez participantes. Luego se procedió a construir las siguientes categorías: Significado personal del deporte, causas del retiro, significado personal del retiro, reacciones frente al retiro, impacto del retiro, recursos de adaptación y satisfacción actual. Los resultados revelaron que para cada participante la experiencia del retiro fue vivenciada de manera única, generando un impacto negativo en la vida del deportista, en su mayoría. No obstante, durante el proceso de adaptación surgieron recursos personales y sociales que ayudaron al atleta a afrontar con éxito esta difícil etapa.

Palabras clave: Retiro deportivo, Deporte de alto rendimiento, Impacto, Adaptación.

\section{ABSTRACT}

The investigation seeks to know about the retirement experience of elite athletes, in Lima, Peru. This study was developed under a qualitative, exploratory and descriptive approach, using a phenomenological methodology. To gather information, it was used an entry data forms and semi-structured interviews with the ten participants. The categories that allowed the analysis of information were: the sport personal meaning, retirement causes, personal meaning of retreat, retirement reaction, retreat impact, adaptation resources and current satisfaction. The results revealed that each participant experienced the retreat in a unique way, generating, mostly, a negative impact on the life of the athlete. However, during the adaptation process there were personal and social resources that helped the athlete to face successfully this difficult stage.

Key Words: Sport retirement, Elite sport, Impact, Adaptation. 


\section{CAPÍTULO I: PLANTEAMIENTO DEL PROBLEMA}

\subsection{Descripción del problema}

En muchos de los deportes, sobre todo en los más físicos y de contacto, el promedio de duración de una carrera deportiva es de aproximadamente diez o quince años; de manera que, muchos le ponen fin a su carrera entre los veinte y cuarenta años. En comparación con otro tipo de profesiones, el deportista tiene a nivel laboral una vida corta; es decir, que cuando su carrera termina, todavía se encuentran en buen estado físico y mental. Frente a ello, el atleta está en la facultad de desenvolverse y desempeñarse en otros roles y actividades (Torregrosa, Sánchez y Cruz, 2004). Sin embargo, podrían llegar a aparecer dificultades para la adaptación, ya que la vida deportiva es diferente a la dinámica regular de una vida en sociedad. De este modo, el mayor problema surge cuando los deportistas no toman consciencia que al finalizar la carrera deportiva deben enfrentarse al mundo real, en el que necesitan reinsertarse a nivel socio-laboral. Asimismo, el abandono de la disciplina deportiva implica una serie de cambios drásticos en la vida del atleta: distanciamiento de sus compañeros, por lo que deben establecer nuevas relaciones; buscar una nueva función social, asumiendo nuevos roles y encontrando otra actividad a la cual dedicarse; implica, también, un cambio en la rutina y en el estilo de vida; así como, se necesita reajustar el aspecto económico, entre otros (Benés, 2018). Todo ello, puede generarle problemas al ex deportista a nivel afectivo, social, psicológico y fisiológico. 
Se toma como ejemplo una investigación, en la cual se encontró que el 39\% de la muestra de ex deportistas, sufre de ansiedad y depresión al retirarse. Además, entre el $5 \%$ y el $42 \%$ mencionó que sufren de algún problema de salud mental (Gouttebarge, Frings-Dresen y Sluiter, 2015). Por otro lado, a nivel físico, se halló en un estudio, que el $43 \%$ de los participantes consideraron que la aptitud física había empeorado después del retiro; así como su peso había aumentado (Cury, Ferreira y Leite de Barros, 2008). Asimismo, en cuanto al aspecto social, se menciona que el reconocimiento social influye fuertemente en la forma en el que el deportista experimenta el retiro, puesto que el prestigio, la atención del medio y el reconocimiento cambian; y si el atleta ha basado en ello su valor personal, la retirada podría llegar a convertirse en un periodo difícil (González y Bedoya, 2008). Frente a ello, se observa que el retiro implica todo un proceso de asimilación para el deportista, que suele iniciar con una sensación de pérdida, al verse afectada una parte o la totalidad de su identidad. Asimismo, debe adaptarse a un estilo de vida distinto, para el cual la mayor parte de ellos no están preparados, ya que a pesar de ser un periodo de muchos cambios (Gonzáles y Bedoya, 2008), el interés por el bienestar y la atención que se les brinda a los deportistas suele disminuir o desaparecer una vez que están retirados. Es decir, que el ex deportista, probablemente, deja de recibir apoyo por parte de las diversas entidades (entrenador, fisioterapeuta, psicólogo deportivo, nutricionista, etc.) que, anteriormente, estuvieron ligadas a su evolución y desarrollo deportivo; dejando que llegue a esta etapa sin ningún tipo de soporte ni preparación que facilite el proceso de transición (Bestard, 2015). 
Es por ello, que se han visto casos de deportistas que al final de su carrera deportiva no pudieron adaptarse adecuadamente, y terminaron tomando malas decisiones que los llevaron a la pobreza, a la adicción e inclusive a la muerte (Pizarro, 2015). Esta no es una realidad ajena a nuestro país; puesto que similar es el caso de uno de nuestros deportistas, quien después de haber sido una estrella a nivel nacional e internacional, habiendo percibido grandes pagos por sus contratos, en la actualidad se encuentra viviendo en un barrio modesto de Lima, con problemas financieros, debido a que no supo administrar adecuadamente su dinero (Giraldo, 2017).

Con el transcurso de los años, países más avanzados a nivel deportivo, han desarrollado una mayor preocupación por el análisis y estudio de la calidad de vida que llevan los deportistas una vez retirados, de manera que se les pueda brindar apoyo y acompañamiento psicológico durante este periodo (Carlin y Garcés de los Fayos, 2012). En tanto en el Perú, la psicología deportiva todavía se encuentra poco desarrollada, y este tema en particular no cuenta con investigaciones que hablen sobre la forma en la que nuestros deportistas enfrentan el retiro. Como menciona Nieri (2007), presidente de la Asociación Peruana de Psicología del Deporte, en la actualidad esta especialidad continúa siendo una disciplina poco reconocida por parte de los profesionales del deporte. De esta manera, la necesidad de un acompañamiento psicológico en la etapa de retiro se ve olvidada, dejando solos a los deportistas de élite en este periodo, trayendo consigo consecuencias negativas y ocasionando problemas a algunos de ellos. Por lo pronto, en la actualidad, el Instituto Peruano del Deporte (IPD, 2018), siendo el ente rector del sistema deportivo nacional, no considera dentro de sus funciones ningún aspecto 
relacionado a los deportistas retirados, tampoco ha planteado ningún trabajo o investigación dirigidos a la mencionada población.

En base a lo descrito, se observa que el retiro puede volverse una etapa difícil para el deportista, en el que su bienestar y calidad de vida pueden verse afectados. No obstante, esta situación no se presenta en todos los casos. Es por ello, que se plantea la siguiente pregunta de investigación: ¿Cómo es la experiencia del retiro en el deportista de alto rendimiento en Lima? De esta manera, se busca conocer la experiencia personal del participante durante el periodo posterior a la carrera deportiva; así como los recursos que lo ayudaron a adaptarse, y los que no, a esta nueva etapa; tendiendo como propósito contribuir al conocimiento de las necesidades que tienen los deportistas durante este periodo, facilitando el proceso de transición y así poder brindar un soporte adecuado.

\subsection{Justificación y relevancia}

El deporte cumple un papel fundamental en la sociedad de un país, formando personas que contribuyen en el desarrollo comunitario, transfiriendo sus enseñanzas a otros en el plano deportivo y personal, convirtiéndose en agentes de cambio, inclusive a su retiro, ya que los ex deportistas desempeñan un rol en la sociedad, siendo modelos a seguir para muchas personas. En base a esta premisa es que la experiencia del deportista peruano retirado debe ser estudiada, puesto que se vuelve un periodo crucial en su vida, pudiendo generar un impacto negativo, que llegue a repercutir en él mismo y en la sociedad (Cury et al., 2008). 
En este contexto se hace evidente que la atención no debe estar solo en formar buenos deportistas a nivel físico o técnico, sino que es necesario facilitarles estrategias y recursos psicológicos e intelectuales que permitan un tránsito saludable y adecuado para la vida luego de culminada la carrera deportiva. De manera, que logren una reinserción laboral, social y psicológica adecuada (Alfermann y Stabulova, 2007). Promoviendo de esta forma una visión integral del deportista, como personas con un pasado, presente y futuro, más allá de la simple competencia deportiva.

Según Tornabene (s.f.), el deportista debe tener un entrenamiento a nivel físico y táctico, junto con un soporte a nivel psicológico, para que se le brinden herramientas no solo para fomentar su crecimiento deportivo, sino, también, su desarrollo personal y social; a través de diversos programas de asesoramiento vocacional y ocupacional para facilitar su adaptación a la vida fuera del deporte.

Es por ello que el estudio planteado constituye un tema de gran impacto a nivel nacional, ya que recoge información novedosa acerca de la experiencia del deportista retirado, investigando sobre las áreas en las cuales impacta esta etapa; así como, conocer sobre los recursos con los cuales cuenta para afrontar este periodo; por último, en base a la información recolectada se pretende generar intervenciones que orienten el apoyo al ex deportista por parte de las entidades relacionadas, de manera que se asegure el bienestar y la calidad de vida de éstos integrantes de nuestra sociedad; logrando así que el retiro, a pesar de ser una etapa dura e inclusive traumática, pueda concluir en un crecimiento personal y en una redefinición de ellos mismos, ya que bien trabajado, puede convertirse en un momento de transición, 
donde se abra la posibilidad para "reinventarse" y salir fortalecido. De esta manera, los nuevos deportistas, inclusive la sociedad, se verá beneficiada, al tener ex deportistas que sirvan de modelo para incentivar valores y competencias que fomenten el desarrollo de nuestro país.

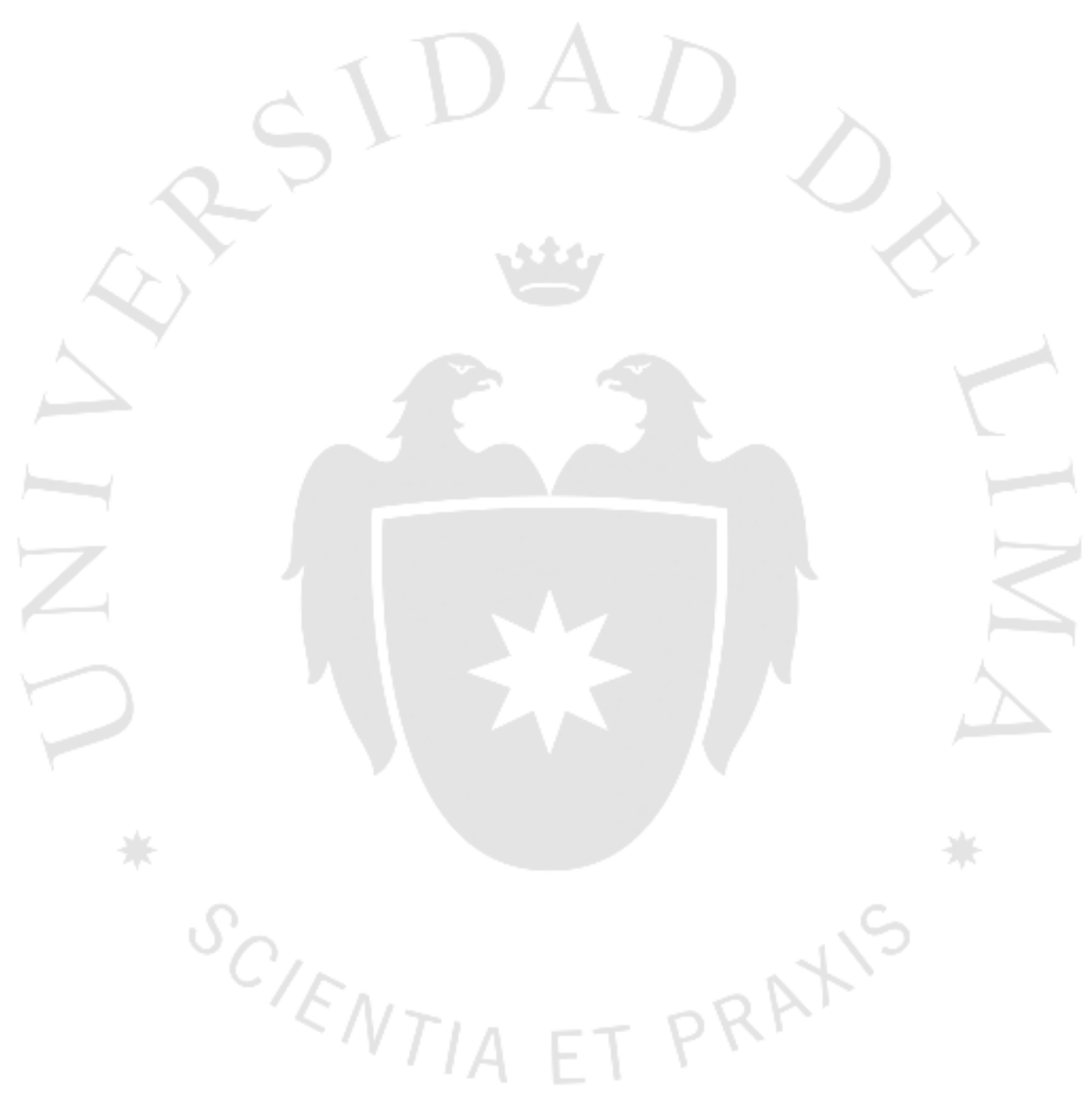




\section{CAPÍTULO II: MARCO TEÓRICO}

En este capítulo se hablará, en primer lugar, acerca del Deporte a nivel global, siendo importante dar a conocer el contexto actual. Luego, sobre el deportista de alta competición, describiendo su desarrollo, dentro del campo deportivo y fuera del él. Después, se tratará el tema del retiro deportivo y cómo es experimentado. Por último, se hace mención de la Psicología Deportiva como un área en desarrollo en el Perú; así como, de los aportes que ésta brinda a los deportistas, tanto durante la carrera deportiva como llegada la hora del retiro.

\subsection{El Deporte}

En la actualidad, cuando se habla acerca del significado de la palabra "Deporte", se plantea una concepción polisémica, es decir que sus significados van a variar según el origen y la cultura de quien lo utilice (Hernández y Carballo, 2002). Muchas veces se suele confundir el concepto de deporte y de actividad física; no obstante, ambos tienen un significado diferente. En el caso de la actividad física, ésta se define como todo movimiento que genera un trabajo de los músculos produciendo como consecuencia un gasto de energía. Sin embargo, solo se dice que es actividad física cuando el movimiento provoca un gasto energético por encima de los parámetros basales del individuo (gasto energético en reposo). Por otro lado, se considera "ejercicio físico" a toda actividad física programada y repetitiva para mejorar las funciones fisiológicas. En muchas ocasiones las personas que realizan ejercicio físico acaban desembocando en un entrenamiento, lo cual implica que haya una sobrecarga de trabajo muscular con distintas variables, teniendo como 
objetivo conseguir una determinada adaptación o mejoría fisiológica para alcanzar determinadas metas. Frente a ello, se entiende el concepto de deporte como la realización de ejercicio físico aplicado a un entrenamiento o competencia, estando sujeto a normas reglamentarias (Vicente-Rodríguez et al., 2016).

Para fines del presente estudio, cuando se hable de deporte, esta se centrará específicamente en deportes de élite o de alta competición.

\subsubsection{El deporte de alta competición}

Se considera deporte de alto rendimiento o de élite a la práctica de una disciplina deportiva con rigurosidad y compromiso, de manera que el deportista desarrolle habilidades específicas, y alcance su máximo rendimiento y desempeño en el área donde se especialice. Tiene como principal objetivo que los deportistas rindan al máximo de sus capacidades, respetando siempre las reglas impuestas, con el propósito de destacar y alcanzar el triunfo. Para ello, es necesario que el deportista se comprometa en su totalidad (Gimeno, Buceta y Pérez-Lantada, 2007).

\subsection{El Deportista de Alta Competición}

Se le llama deportista de alto rendimiento o de élite a los individuos que son capaces de tener un desempeño deportivo por encima de los niveles regulares, entrenando de manera constante e intensivamente para alcanzar resultados excelentes, tanto a nivel nacional como internacional. Este entrenamiento involucra una práctica regular y sistemática, aproximadamente entre 2 y 6 horas 
diarias, de 5 a 7 días a la semana (dependiendo del tipo de deporte que se practica) (García-Naveira, 2010). Cabe señalar que para el presente estudio se utilizará el término "atleta" en su sentido amplio de la palabra, como un sinónimo para deportista.

Asimismo, con el correr del tiempo, el nivel de exigencia al que se ve sujeto el deportista ha aumentado, generando mayor estrés, que puede afectar el desempeño, tanto en los entrenamientos como en las competencias. De manera que es necesario disponer de recursos (cognitivos y fisiológicos) para afrontar estas circunstancias (Ruiz y Lorenzo, 2008).

Por otro lado, es un error pensar que todos los deportistas poseen las mismas características y cualidades; cada individuo es único y sus características varían dependiendo de su personalidad, del deporte que realizan y de otros factores. No obstante, ha sido comprobado que los atletas comparten algunas características en común:

En un estudio realizado por el Greenleaf, Gould y Dieffenbach (2001), en Estados Unidos, a 10 deportistas olímpicos, se encontraron características psicológicas, siendo las más destacadas:

a) Alta motivación y compromiso: la competitividad se fortalecía de un deseo personal o motivación intrínseca para llegar a alcanzar sus metas.

b) Optimismo y positivismo: ante situaciones difíciles estos atletas tenían la capacidad de ver el lado positivo, saliendo en busca de una solución.

c) Perfeccionistas: se halló dos tipos de perfeccionistas, los adaptados que se caracterizaban por tener metas muy altas (pero alcanzables) y trabajan 
organizadamente para alcanzarlas. En cuanto a los perfeccionistas desencajados, fijan metas elevadas, pero en muchas ocasiones llegan a ser inalcanzables, generando frustración, y preocupación excesiva a fallar y a ser criticados.

d) Habilidad para enfocarse: contaban con la capacidad para concentrarse en los factores claves relacionados con el rendimiento, mientras bloqueaban cualquier estímulo distractor.

e) Capacidad para manejar el estrés: permite manejar mejor la ansiedad durante el entrenamiento y la competencia, trabajando bajo presión de manera eficiente.

Es importante mencionar, que un deportista de alta competición puede llegar a convertirse en un atleta profesional, pero para ello debe dedicarse de manera regular a la práctica de su disciplina deportiva a cambio de una remuneración económica, sirviéndole como medio de vida (Jofré, 2014).

\subsubsection{El desarrollo del deportista}

Para explicar el proceso de desarrollo del deportista, se utiliza el modelo que proponen Wylleman y Lavallee (2003), el cual busca concebir de manera integral al atleta, teniendo presente no solo su desarrollo a nivel deportivo, sino a nivel global. 
Figura 2.1

Modelo de desarrollo de la carrera deportiva.

\begin{tabular}{|c|c|c|c|c|c|c|c|}
\hline Edad & \multicolumn{2}{|c|}{10} & & 15 & 20 & & 35 \\
\hline $\begin{array}{l}\text { Carrera } \\
\text { deportiva }\end{array}$ & \multicolumn{2}{|c|}{ Iniciación } & \multicolumn{2}{|c|}{ Desarrollo } & \multicolumn{2}{|c|}{$\begin{array}{l}\text { Maestría } \\
\text { Perfeccionamiento }\end{array}$} & $\begin{array}{c}\text { Retirada } \\
\text { Reubicación }\end{array}$ \\
\hline $\begin{array}{l}\text { Desarrollo } \\
\text { individual }\end{array}$ & Infancia & \multicolumn{2}{|c|}{ Pubertad } & Adolescencia & Juventud & \multicolumn{2}{|r|}{ Edad Adulta } \\
\hline $\begin{array}{l}\text { Evolución } \\
\text { Otros } \\
\text { significativos }\end{array}$ & \multicolumn{2}{|c|}{$\begin{array}{c}\text { Padres } \\
\text { Hermanos } \\
\text { Amigos }\end{array}$} & \multicolumn{2}{|r|}{$\begin{array}{c}\text { Amigos } \\
\text { Entrenador } \\
\text { Padres }\end{array}$} & $\begin{array}{c}\text { Pareja } \\
\text { Entrenador }\end{array}$ & \multicolumn{2}{|r|}{$\begin{array}{c}\text { Familia } \\
\text { (Entrenador) }\end{array}$} \\
\hline $\begin{array}{l}\text { Desarrollo } \\
\text { Académico } \\
\text { Vocacional }\end{array}$ & \multicolumn{2}{|c|}{$\begin{array}{c}\text { Educación } \\
\text { primaria }\end{array}$} & \multicolumn{2}{|c|}{$\begin{array}{l}\text { Educación } \\
\text { secundaria }\end{array}$} & $\begin{array}{l}\text { Educación } \\
\text { superior }\end{array}$ & \multicolumn{2}{|c|}{$\begin{array}{l}\text { Formación vocacional } \\
\text { Ocupación profesional }\end{array}$} \\
\hline
\end{tabular}

Fuente: Wylleman y Lavallee (2003)

En dicho modelo se evidencia que a lo largo de la carrera deportiva del atleta se toma en cuenta cuatro niveles, cada uno conformado por distintas etapas.

En el primer nivel se puede observar el camino deportivo que recorre un deportista de alto rendimiento, teniendo como promedio de inicio los 5 años.

Según Williams, (1991) la fuerte identificación que sienten los atletas con su disciplina deportiva se inicia en la infancia, intensificándose con el pasar de los años. Esta afirmación se basa en el planteamiento de E. Erickson, el cual refiere que entre los 7 y 12 años el sentido de identidad del niño comienza a incrementar. Alrededor de los 25 años el deportista atraviesa la etapa de perfeccionamiento, es en esta etapa que el deportista se encuentra en su mejor momento. No obstante, aproximadamente a los 30 años comienza su declive deportivo, siendo los 35 años la edad promedio para el 
retiro. Messner (1992) refiere que, en comparación a otras profesiones, el deporte es la única carrera en la que se considera a un joven de 27 años como un "veterano" y un atleta entre los 30035 años un "viejo". Cabe señalar, que el desarrollo del deportista suele darse como se menciona en el cuadro; sin embargo, en ocasiones, puede haber deportistas precoces que alcancen el nivel de maestría antes de los 20 años.

En el segundo nivel se habla acerca del desarrollo individual del deportista; como la persona regular que es, pasa por las diferentes etapas de desarrollo como la infancia, la pubertad, la adolescencia, la juventud y la adultez. Frente a ello, se hace evidente que al momento del retiro el deportista aún continúa siendo una persona activa y autónoma, en perfectas capacidades físicas y cognitivas.

En el tercer nivel se encuentra el desarrollo psicosocial del individuo, en él se observa la evolución de las relaciones con el entorno, desde la familia nuclear en la primera etapa, hasta el establecimiento de una familia propia en la última etapa, teniendo siempre la presencia importante de los entrenadores en la vida del sujeto.

Por último, en el cuarto nivel se habla acerca del desarrollo académico y vocacional, que incluye la educación escolar (primaria y secundaria), la educación superior y la formación y ocupación profesional. Frente a ello, se evidencia que cuando las personas regulares están pasando por la cuarta etapa, la ocupación profesional, en el ámbito deportivo ésta ya está terminando (Torregrosa et al., 2004). 
En resumen, este modelo muestra que el ciclo competitivo de un deportista no durará por siempre; sino por el contrario, solo forma una parte del periodo productivo de su vida. Por lo general, el retiro deportivo se da a edades muy tempranas, de manera que los deportistas normalmente suelen continuar con su carrera laboral (Wylleman, Alferman y Lavallee, 2004).

\subsection{El Final de la Carrera Deportiva}

Cuando se habla acerca de los deportistas de alto rendimiento, se menciona solo acerca de sus épocas de gloria y en las que estaban "bajo el reflector"; no obstante, se ha evidenciado que hay toda una historia detrás del retiro de un deportista. Como menciona Romina Plataroti (2008), psicóloga deportiva y ex deportista olímpica:

Esto que parece tan fácil no lo es tanto. La pregunta que me realizaba en el momento de mi retiro, como luego de la experiencia vivida en aquel curso era la siguiente: si yo sólo soy por lo que he realizado en mi carrera deportiva, si las personas me reconocen sólo por mis medallas y logros, si ya no me encuentro participando de las competencias donde los obtuve; ¿ahora quién soy? (p. 132).

Frente a ello, queda en evidencia que el periodo de retiro implica un cambio y una reestructuración en el estilo de vida que ha llevado el atleta por varios años. 


\subsubsection{Causas del retiro}

El final de una carrera deportiva puede ser causado por múltiples motivos, y suele ser el resultado de un largo proceso de razonamiento y toma de decisiones. Al momento del retiro hay grandes diferencias en las reacciones de los atletas. Independientemente del motivo por el cual el deportista le haya puesto fin a su carrera, la sensación subjetiva de éste sobre la decisión voluntaria o forzada es un determinante clave para la adaptación. No obstante, se ha observado que el retiro voluntario suele contribuir a una transición menos dura (Carlin y Garcés de los Fayos, 2012).

En el IX Congreso Nacional de Psicología de la Actividad Física y el Deporte, los investigadores Gonzáles y Bedoya (2003) presentaron un análisis descriptivo de la retirada deportiva, en el que encontraron que las lesiones, la incompatibilidad entre estudios/trabajo y carrera deportiva, la propia decisión, la falta de motivación, la disminución del rendimiento y de los ingresos económicos, son los motivos de retirada deportiva más frecuentes (citado en González y Bedoya, 2008).

En base a ello, como menciona Roffé (2000), existen dos situaciones para la jubilación de los deportistas. La primera, cuando se retiran voluntariamente porque siente que su rendimiento está en declive, han sufrido una lesión grave o consideran que ya cumplieron sus objetivos, tomando en cuenta que están psicológicamente cansado y el ambiente del deporte se desgastó. La segunda, cuando el retiro es forzado porque el deportista no rinde más o los dirigentes 
o técnicos deciden que no están en condiciones de jugar por el club o la selección.

Asimsimo, Lavallee, Golby y Lavallee (2002) refieren que una de las razones principales de retiro es la edad cronológica, puesto que la motivación psicológica, el estatus social y las capacidades físicas pueden llegar a complicar la capacidad individual para continuar compitiendo a un nivel de élite (citado en Pizarro, 2015).

Por último, existen diversas causas por las que un atleta puede detener su participación en el deporte de alto rendimiento, cortando el curso normal de su vida deportiva. Es así, que el problema fundamental, de la mayor parte de los deportistas, es que se ven forzados a retirarse. A pesar de ser conscientes, probablemente, que en algún momento el final de su carrera llegará, son pocos los que se encuentran realmente preparados para afrontar esta nueva etapa. De esta manera, el proceso de adaptación para la vida luego de la carrera deportiva, en ocasiones, puede ser diferente dependiendo de la causa que ha llevado a dicho fin (González y Bedoya, 2008).

\subsubsection{Reacciones frente al retiro}

En una investigación realizada por Cury et al. (2008), se halló que en relación a las reacciones emocionales vividas por los deportistas al momento del retiro, se observaron la predominancia de algunas emociones. El $50.6 \%$ de los exjugadores sintió tristeza en el momento de la transición a una nueva carrera, el $36.7 \%$ se sintieron conformes en cuanto a la decisión. Asimismo, el 17.7\% 
de los participantes sintió felicidad en ese momento, el $6.3 \%$ se sintieron tensos, el 5.1\% sintió miedo, el 5.1\% quedaron deprimidos, el 3.8\% sintió rabia, el 3.8\% quedaron resentidos, el 1.3\% se sintió culpable y ninguno de los participantes hizo referencia a sentimiento de desesperación.

\subsubsection{Impacto del retiro}

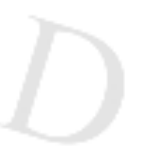

Cury et al. (2008) refieren que los deportistas al retirarse pasan por un periodo de crisis; la cual requiere ajustes a nivel ocupacional, financiero, psicológico y social. De esta manera, se puede observar que el retiro impacta de diversas maneras en las diferentes áreas de la vida de un atleta.

\section{Personal}

El retiro deportivo se experimenta muchas veces como un duelo asociado a la culminación de una etapa de la vida. Asimismo, muchas veces, se presenta una crisis de identidad, siendo ésta producto del grado en que el deportista se ha identificado con su rol deportivo, es decir, que, a mayor identificación, mayor será la intensidad de la crisis que tendrá que enfrentar cuando llegue la hora del retiro. En relación a ello, en la literatura se habla una sensación de pérdida por el abandono a la actividad que se ha realizado con mucha dedicación por varios años; con ello, no solo se habla de la pérdida de un estilo de vida, sino que también se ha dejado atrás una identidad. Frente a ello, el deportista se encuentra ante la interrogante de cómo hacer para incorporarse en otros ámbitos desconocidos y como hacer frente a otras facetas de la vida que no han 
podido ser completamente desarrolladas debido a todo el tiempo dedicado a los entrenamientos intensos. Asimismo, el cambio de rol en la sociedad implica muchas veces un desafío, empezando por insertarse al mundo cuando todavía su identidad no se encuentra del todo clara; de manera que el individuo atraviesa por un periodo de desorientación, en el cual el sujeto debe adaptarse a su nueva rutina diaria, a su entorno, a sus nuevas relaciones sociales y a su propio cuerpo; así como de crisis emocional, por la pérdida de dicha identidad deportiva (Gonzáles y Bedoya, 2008).

Frente a lo mencionado, queda en evidencia que el estilo de respuesta que tenga el deportista frente al retiro va a depender del enfoque que éste le ha dado a su carrera deportiva y el espacio que ésta ha ocupado en su identidad. Es decir, que un tipo de identidad deportiva elevada puede generar más problemas durante el retiro si ésta se mantiene; en contraste con los atletas con una identidad deportiva menor (Pizarro, 2015; y Alfermann y Stabulova, 2007). En otra investigación, en la que se analizó la relación entre identidad atlética y el impacto en la salud mental después del retiro. Se encontró que una identidad que está exclusiva y fuertemente ligada al deporte impacta negativamente en la salud mental de los atletas, generando sintomatología depresiva y un estado de ansiedad. Se observó que los atletas que tenían una identidad deportiva elevada reportaron sentir, significativamente, más síntomas depresivos que los atletas con una identidad deportiva baja; así como, la aparición de ansiedad como estado. Asimismo, no se encontró relación entre la identidad deportiva, florecimiento, satisfacción con la vida y vitalidad subjetiva (Giannone, 2016). 
Por otro lado, en la investigación de Cury et al. (2008), se halló que entre las consecuencias físicas de concluir la carrera deportiva, los resultados evidencian que el $43 \%$ de los entrevistados percibieron que la aptitud física empeoró después de haberse retirado. Según la información recogida durante las entrevistas, el peso de los participantes aumentó y no mantienen el mismo nivel de ejercitación. Además, se encontró que la condición física no ha mejorado para ninguno de los entrevistados. Asimismo, los atletas experimentaron distress durante el retiro, ya que también sintieron la tristeza y la nostalgia de no poder competir nunca más en su deporte a nivel de alta competencia.

Dicho estudio, también, recoge los testimonios recopilados por Rimoli (2002) del diario "De Tarde", de deportistas destacados en Brasil que ilustran la situación descrita; como el ex futbolista Pele, quien dice: “Aceptar que llegó la hora de parar es terrible, la depresión surgió cuando la hora llegó”. En la misma entrevista, el jugador de básquet Oscar mencionó: “Sé que la hora de parar está llegando o ya pasó. Solo que son más de 25 años haciendo lo mismo. No voy a negar que es duro pensar que no estaré jugando más un partido oficial. Aún más porque estoy bien físicamente y no estoy obstaculizando al equipo. Un ex atleta también refiere: "Queda eternamente la nostalgia" (citado en Cury et al., 2008).

Finalmente, en el estudio se concluyó, que en el retiro se suele presentar una crisis, alivio o una combinación de ambos, esto va a depender de la percepción que tengan los atletas frente al retiro. De manera, que dejar la carrera deportiva tiende a ser un momento difícil en la vida de un atleta, pues siempre es 
necesario adaptarse a nuevos roles, tanto sociales como profesionales. Asimismo, se encontró que la adaptación es más difícil cuando el participante se siente fuertemente identificado con la figura de deportista; presentando, después de años de dedicarse exclusivamente al deporte, dificultades psicológicas y experimentan tristeza (Cury et al., 2008).

Según Blinde y Stratta (1992), genera preocupación el gran número de deportistas de élite que experimentaron efectos traumáticos al término de su carrera deportiva, incluyendo alcoholismo y abusos de sustancias, depresión aguda, trastornos de alimentación, pérdida de identidad, disminución de confianza en uno mismo e inclusive intento de suicidio (citado en Pizarro, 2015).

Por último, en un estudio se halló que el $26 \%$ de los jugadores vigentes asegura haber sufrido ansiedad y depresión por diferentes razones; no obstante, la cifra aumenta al 39\% entre los futbolistas retirados. Asimismo, entre el 5\% y el $42 \%$ de los exfutbolistas indicaron que sufren de algún problema de salud mental; en especial, síntomas de ansiedad y depresión, y prácticas nutricionales inadecuadas, siendo los más reconocidos en 2 de cada 5 futbolistas. En adición, solo el 3\% de los futbolistas retirados informó que padecía de baja autoestima; así como, el $15 \%$ al $20 \%$ mencionó sentir malestar y astenia. En base a ello, el informe revela que el cambio de estilo de vida que se produce por el retiro puede llegar a tener graves consecuencias, ya que disminuyen la intensa carga física, de alguna manera pierden la organización diaria a la que estaban acostumbrados, se reduce el apoyo social que recibían por parte de los 
entrenadores y compañeros, ahora deben encontrar un "nuevo espacio en la sociedad" y una nueva ocupación. Es por ello, que sus probabilidades de desarrollar algunos problemas de salud mental aumentan durante esta etapa. En base a ello, se concluye que el periodo posterior al retiro del futbol profesional es un momento crítico para muchos de los jugadores (Gouttebarge, Frings-Dresen y Sluiter, 2015).

\section{Social}

Por otro lado, muchas veces el reconocimiento social influye fuertemente en la percepción del retiro, ya que la situación de prestigio, la atención del medio y reconocimiento cambia drásticamente una vez que el deportista se retira; de esta manera, si el atleta ha gestionado su valoración personal entorno a los aplausos, éxitos, elogios, etc. el momento de la retirada será más difícil. Es decir, que mientras más reconocido y aclamado sea el deportista habrá mayores posibilidades de que aparezcan problemas, como el temor a dejar de ser reconocido y valorado. Es por ello, que se busca evitar que los atletas de élite se dediquen de manera casi exclusiva a su rol deportivo; de manera que se les exponga a otro tipo de experiencias, a nivel recreativo, social y educacional. Y así, el atleta podrá desarrollar otro tipo de intereses y no solo encasillarse en el área deportiva; disminuyendo la probabilidad que el auto concepto dependa del éxito deportivo (González y Bedoya, 2008). 


\section{Económico}

Otra área importante que puede llegar a generar consecuencias negativas en la vida del deportista retirado, es el aspecto económico. Ya que como menciona Prado (2013) en su artículo, a lo largo de la historia del deporte se han encontrado varios casos de atletas que han terminado en bancarrota, ya que no fueron cuidadosos y precavidos con sus finanzas, particularmente, por no haber ahorrado para su retiro. Es de vital importancia que el deportista ahorre durante su carrera deportiva para su retiro, puesto que la vida laboral de un atleta es por lo general más corta, pudiendo existir momentos de mayor o menor éxito deportivo, generando altos o bajos ingresos económicos. De manera, que no ahorrar para el retiro puede traer consecuencias graves. Las estadísticas muestran que el $60 \%$ de basquetbolistas retirados de la NBA terminan en la quiebra 5 años después del retiro. Asimismo, el 78\% de ex deportistas de la NFL terminan en bancarrota tras solo 2 años de retiro. Y el $50 \%$ de ex futbolistas de ligas europeas, también, se quedaron quebrados al poco tiempo de retirarse. Además, hay muchos casos de ex boxeadores que se quedan sin dinero al concluir su carrera, terminando en la miseria. No obstante, en la actualidad, hay una mayor preocupación por fomentar el ahorro para el retiro, siendo un tema de gran relevancia a nivel mundial. Han aparecido programas que ayudan a los deportistas, como el Programa de Educación Financiera para el estudiante-atleta en Estados Unidos y el Programa ayuda a ex futbolistas profesionales de Xpro en Reino Unido e Irlanda, brindando información, 
asesorías y servicios sobre seguros, inversiones e hipotecas; entre otros diversos programas.

\subsection{El proceso de adaptación al retiro}

En unos estudios realizados, como los de Schmidt y Hackfort (2001) en el cual compararon a ex deportistas de élite franceses y alemanes, usando el Athletic and Post-Athletic Questionnaire, de Huang, Schmidt, Hackfort y Si (2001); así como los de Hackfort y Huang (2005), que utilizaron este mismo instrumento para comparar atletas alemanes y chinos retirados; hallaron que la planificación del retiro, el final voluntario, el cambio de identidad, y un afrontamiento activo son los factores que hacen que la adaptación al nuevo estilo de vida, sea más fácil (citado en Carlin y Garcés de los Fayos, 2012).

Siguiendo esta misma línea, Alfermann y Stabulova (2007), plantean cuatro determinantes que afectan la adaptación del deportista. En primer lugar, se habla acerca de la libertad de decisión, es decir, si es que el retiro fue voluntario o involuntario. Frente a ello, mencionan que los atletas que tienen mayor libertad para decidir el final de su carrera deportiva, tienden a experimentar más emociones de valencia positiva que de valencia negativa; cabe señalar que a partir de ahora se hará referencia a las emociones de valencia positiva y negativa como emociones positivas y negativas; en contraste de los que son forzados a retirarse, puesto que ellos sufren de estrés y se les dificulta más la adaptación. 
El segundo factor, vendría a ser si el deportista ha planificado o no, su vida para una vez culminada la carrera deportiva. Puesto que el planificar con anticipación va a permitir al atleta tener una transición más corta y fluida a la vida fuera de su disciplina deportiva, dando lugar a experimentar emociones satisfactorias. Asimismo, a pesar que el retiro es algo que indudablemente llegará para el deportista en algún momento, para la mayor parte de los atletas es difícil anticiparse y prepararse para este evento. Es por ello, que la falta de preparación se vuelve uno de los determinantes principales al momento del ajuste al retiro. Es importante que los deportistas sean conscientes de que su carrera no durará para siempre y que, eventualmente, al retirarse a una edad todavía productiva, necesitarán otra ocupación. En relación a ello, Pizarro (2015) refiere que la planificación para la post carrera permite una transición más corta y fluida hacia la vida personal y el mundo laboral fuera del deporte, permitiendo que el deportista experimente emociones satisfactorias. El poder planificar su vida antes de retirarse le brinda al deportista sentimientos de control sobre la situación, amplía la propia identidad, es decir, le da la oportunidad al atleta de verse más allá del ámbito deportivo. Esto tiene como consecuencia una menor experimentación de emociones negativas al llegar la hora del retiro, un tiempo de adaptación más rápido y mayor satisfacción con la vida.

En tercer lugar, se encuentra el tipo de identidad deportiva, es decir la imagen que el deportista tiene de sí mismo de acuerdo al vínculo que ha establecido con su disciplina deportiva. 
Por último, los recursos personales (el nivel de educación, las competencias/habilidades personales o los objetivos propuestos para la post carrera) y los recursos sociales (familia, amigos y otros servicios que brinden apoyo) podrían llegar a fomentar una mejor adaptación durante el proceso de retiro.

En otra investigación, realizada por Duque-Ingunza y Dosil (2017) se halló que el ajuste positivo al retiro está relacionado a la consecución de objetivos deportivos, observándose que los sentimientos de logro promueven una transición más armoniosa. Y siguiendo esta línea, Lorenzo y Bueno (2012) refieren que la consecución de objetivos deportivos va a generar que el deportista comience a planificar su retiro, facilitando el proceso de retiro.

Por otro lado, los futbolistas que concluyeron su carrera deportiva a causa de haber disminuido su rendimiento, terminaron sufriendo una mayor pérdida de estatus y de auto-confianza, a diferencia de los que se retiraron por otras razones. Esto puede generarse debido a que los deportistas que pierden habilidades, terminan asociando el bajo rendimiento a el fracaso personal. Asimismo, se encontró que el retiro deportivo no supuso distress para los atletas, sino que los participantes supieron manejar positiva o muy positivamente esta etapa. Su actitud durante los primeros meses después de retirarse fue positiva y en general se encuentran satisfechos con su vida después de haber concluido su carrera deportiva. De esta manera, se observó que la retirada no tiene que ser necesariamente un evento negativo. Además, se hizo evidente que los atletas que se retiraban por causas bajo su control no necesariamente iban a estar mejor preparados para la retirada (Duque-Ingunza y Dosil, 2017). 


\subsubsection{Recursos de Adaptación}

Algunos atletas aceptan el retiro como un acontecimiento obvio, de manera que realizan planes anticipadamente para el momento que llegue esta etapa, y avanzar con éxito. A diferencia de ellos, otros deportistas lucharan durante este proceso siendo forzados a ponerle fin a su carrera. En ocasiones, el retiro de manera voluntaria puede contribuir a un proceso más suave de transición; no obstante, la forma en cómo el deportista afronte esta nueva etapa, no solo va a depender de las causas, sino también de los recursos personales y sociales del atleta. Es por ello, que se debe buscar fortalecer los recursos individuales: la educación, la formación, las competencias y el establecimiento de metas; así como, los recursos sociales: apoyo social de la familia y los servicios de post-carrera (que en el Perú todavía no han sido desarrollados), de manera que se logre una adaptación saludable. Lo cual, da lugar a la exitosa adopción de nuevos roles, tanto en la familia como en el trabajo e inclusive en el sistema deportivo (Carlin y Garcés de los Fayos, 2012).

Asimismo, la visión del retiro como un "proceso" considera que en esta etapa intervienen tres factores; en primer lugar, las características personales del individuo, como la competencia psicosocial, el género, la edad, etc. En segundo lugar, la percepción particular del deportista del proceso, en lo cual interviene su cambio de rol, sus afectos, su nivel de estrés. Y, en tercer lugar, las características de su entorno previas y posteriores a la transición, lo que implica la evaluación de los sistemas de apoyo con los que cuenta el deportista y el apoyo institucional (Wylleman et al., 2004). 
Por otro lado, Lorenzo y Bueno (2012) consideran como recursos para una mejor adaptación al retiro:

a) Tener conciencia de futuro, es decir, que los deportistas deben ser conscientes que una vez retirados es probable que deban trabajar y que el deporte no es lo único en sus vidas, sino solo un aspecto de ella.

b) Planificación del retiro.

c) El aprovechamiento del capital deportivo acumulado, es decir, su popularidad, contactos, conocimientos técnicos y tácticos, y los entornos culturales de sus respectivos deportes.

d) Apoyo social, en mayor parte de la familia. Puesto que, así, como es importante el apoyo de las personas más allegadas al deportista durante su carrera, tanto en las victorias como en los fracasos; igual o más importante es el apoyo durante el retiro.

e) Formación, es decir, que para convertirse en un deportista calificado es necesario dedicarse de manera casi exclusiva a la disciplina deportiva. Este duro régimen de entrenamiento y competencia, puede llegar a generar dificultades para llevar en simultaneo una formación académica. No obstante, el nivel educativo tiende a influir en las oportunidades laborales posteriores al retiro deportivo. Asimismo, es importante mencionar que el deporte brinda al atleta habilidades, como el trabajo en equipo, disciplina, capacidad de toma de decisiones, etc.; que puede transferir a otros ámbitos de su vida, favoreciendo el afrontamiento de la retirada deportiva de manera más positiva. 
Asimismo, cabe mencionar, que un recurso de manera aislada, no asegura un ajuste al retiro fácil y tranquilo. De manera, que el resultado de cómo termina experimentando el deportista el retiro, es la combinación de muchos factores, tanto los factores individuales como las influencias sociales (Cury et al., 2008).

\section{Individuales}

En cuanto a la teoría del retiro deportivo, por mucho tiempo, el final de la carrera deportiva fue visto como un evento singular; no obstante, en la actualidad, ha pasado a ser considerado un "proceso", con el propósito de que el individuo pueda ajustarse adecuadamente a la situación, dándole así una oportunidad al atleta para reinventarse (Wylleman et al., 2004).

Asimismo, siguiendo esta misma línea, de la mirada del retiro como un proceso, los autores Torregrosa, Sánchez y Cruz (2003) mencionan que "la visión puramente retrospectiva de atletas retirados se ha complementado con la visión prospectiva de los deportistas que afrontan el proceso" (p. 217). Es decir, que lo que busca es que el deportista no solo se enfoque en el pasado, en sus "épocas doradas", sino que enfrente su situación actual y tenga una visión de sí a futuro. Se ha demostrado que hacer planes anticipados para la vida después del retiro ayuda considerablemente en el proceso para afrontar la etapa de transición, así como a construir una nueva vida (Carlin y Garcés de los Fayos, 2012). De esta manera, si un deportista no cuenta con objetivos 
ni metas post deportivas podría llegar a condenarse, viviendo solo de sus recuerdos y glorias de anteaño, sin otros incentivos ni retos personales.

Por otro lado, en relación a las estrategias de afrontamiento utilizadas por los deportistas al momento de enfrentar el retiro, se halló que un replanteamiento positivo estaba correlacionado con los tres aspectos de bienestar (florecimiento, satisfacción con la vida y vitalidad subjetiva), de manera que esto muestra que este tipo de estrategia puede ser fundamental para lograr una adaptación positiva. Además, se observaron, también, diversos patrones para afrontar los aspectos de salud mental (ansiedad y depresión). No obstante, se evidenció que el uso de la auto-distracción, la negación, el uso de sustancias, falta de compromiso y sentimiento de culpa, generaban un mal manejo de los síntomas de depresión y ansiedad (Giannone, 2016).

En una investigación, realizada a futbolistas retirados, se encontró que los atletas utilizaban como recursos el contar con opciones e intereses, puesto que el $85.7 \%$ refirió tener algo interesante en qué involucrarse o sentirse absorbidos (trabajo, estudios, una relación, aficiones, etc.); y dentro de este porcentaje, el $45.2 \%$ ya hacía estas actividades mientras competía. Por otro lado, se encontró la percepción de ajuste, es decir, la satisfacción con la vida después de haberse retirado. El $85.7 \%$ mencionó sentirse bastante o muy satisfecho con sus vidas, mientras que solo el $4.8 \%$ refirieron sentirse muy poco satisfechos, y ninguno indico sentirse nada satisfecho. Además, el 69\% percibieron que manejaron positiva o muy positivamente el proceso de transición y el $31 \%$ sintió que lo manejó de manera neutra y ninguno 
consideró haber tenido un manejo negativo. La investigación también encontró entre los recursos de adaptación a la importancia de la experiencia como jugador vs su situación actual. En base a ello, el $42.1 \%$ concluyó que ambas experiencias tienen el mismo nivel de importancia, un $36.9 \%$ considera que la situación actual es la más importante, mientras que el $21.1 \%$ piensa que su experiencia como futbolista fue la más importante. Por último, la preparación mental también fue considerada un recurso de adaptación (Duque-Ingunza y Dosil, 2017).

Finalmente, reportes indican que muchos de los atletas experimentan distress al concluir con su carrera deportiva, percibiendo este evento como negativo, inclusive llegando a ser traumático. En una investigación se encontró que los deportistas que desarrollaron un modelo de trayectoria paralelo, es decir, que además de la actividad deportiva realizaron una carrera universitaria, el proceso de retirada no fue tan duro. Por el contrario, la única deportista que presentó un modelo de trayectoria lineal, es decir, que solo se dedicó exclusivamente a su deporte, refirió que tuvo que enfrentar diversos problemas para adaptarse al retiro, percibiendo una fuerte carga negativa a nivel que le generó el retiro. De manera, que la percepción negativa del retiro aumenta en los atletas que no cuentan con una profesión (Pizarro, 2015).

\section{Sociales}

En los países donde la psicología deportiva tiene una fuerte presencia, se habla acerca del concepto de "retiro deportivo", el cual es la etapa en la que 
el deportista (con la ayuda del entrenador, los integrantes de su equipo y el psicólogo deportivo) toma conciencia y siente la necesidad de ponerle fin a la práctica del deporte de alto rendimiento. De manera que se detecte y se reconozca la disminución de los índices competitivos y de tolerancia de las cargas de entrenamiento, ya que lo que se busca es prepararlo para el posterior desentrenamiento. Es decir, que ésta se convertirá en una etapa de trabajo con el deportista en retiro y se sientan las bases para el desentrenamiento que deberá enfrentar. Para aclarar el término de desentrenamiento, éste se refiere al proceso en el que el atleta pierde el entrenamiento adquirido. Lo que busca es la disminución paulatina, planificada y dosificada de la capacidad de trabajo orgánica deportiva, con el fin de descargar o reducir en el atleta los efectos biológicos de las grandes cargas físicas a las que ha sido sometido durante toda su carrera deportiva. No es bueno para el organismo de un ex deportista parar la actividad física por completo, sino que debe continuar realizando algún tipo de actividad de forma suave; de manera que el organismo del atleta vaya eliminando toda o la mayor parte de la sobrecarga adquirida a lo largo del entrenamiento deportivo. En cuanto menores sean las afectaciones físicas residuales, habrá mayor posibilidad de hablar de un retiro psicológicamente saludable. Para ello debe contar con el apoyo de un equipo multidisciplinar que ayuden a que esta etapa sea lo menos traumática posible, de manera que no deje secuelas, tanto físicas, sociales y psicológicas en quien ha dedicado gran parte de su vida al desarrollo del deporte de su país. Durante este período de retirada cabe la posibilidad que el deportista enfrente una fase 
de depresión, siendo necesario reforzar la preparación psicológica y comunicativa que lo predisponga positivamente para su retiro (Bestard, 2015).

Asimismo, en una investigación realizada en Brasil, se encontró qué la disminución planificada y gradual de la carga física durante el periodo activo es necesaria, ya que beneficiará a los deportistas al retiro (Cury et al., 2008).

En base a lo mencionado, se deduce la importancia de realizar una buena preparación para enfrentar la etapa del retiro que indudablemente llegará; sin embargo, en la actualidad, esta práctica no se da regularmente. Según Vidaurreta y Rojas (2015):

Es hoy...una realidad el hecho de que el retiro deportivo de la práctica activa se realiza sin que se planifique adecuadamente el proceso de desentrenamiento deportivo como parte final de la vida deportiva por parte de las instancias que deberían estar implicadas en ello (p. 3).

En otra investigación, realizada a futbolistas retirados, se encontró que los deportistas consideraban importante para la adaptación al retiro el apoyo social (a nivel emocional, financiero para encontrar trabajo, etc.) tanto de personas como de instituciones. El 78\% mencionaron haber recibido un fuerte apoyo por parte de su pareja o esposa, el $75.6 \%$ se sintieron apoyados por otros miembros de su familia, y el 52.5\% por sus amigos. No obstante, se percibió que la ayuda institucional recibida fue poca o nula, tanto de los entrenadores, como de la federación y el consejo superior de deporte (Duque-Ingunza y Dosil, 2017). 
Por otro lado, en base a los datos recogidos de las preselecciones de Baloncesto Femenino en los años de 1974 al 2000, por parte de la Comisión Nacional de Baloncesto y Federación Cubana de Baloncesto; y Comisión de Atletas Retirados del INDER, en el 2014, se halló que estas mujeres pudieron construir proyectos personales de vida que de acuerdo a sus intereses personales. Frente a ello, se concluyó que esto se debía a que, a pesar de quedar con lesiones físicas, éstas no eran invalidantes para continuar con sus proyectos de vida. Asimismo, los entrenadores tuvieron un rol importante como formadores; así como, la base del entrenamiento deportivo estuvo siempre asociado a la obligatoriedad de la formación docente de las jugadoras y formación en valores. Por otro lado, se brindó una asesoría psicológica a las jugadoras, en las que elaboraron sus planes de vida en los diferentes ámbitos de sus vidas. De igual manera, se estableció una fuerte relación de trabajo entre los Colectivos Pedagógicos y las instancias correspondientes de Medicina y Psicología del Deporte, y de ellos con las deportistas. En base a lo mencionado, se halló que es posible alcanzar un retiro psicológicamente saludable a través del trabajo integrado de quienes están implicados en la preparación deportiva de alto rendimiento (Vidaurreta y Rojas, 2015).

Por último, Richardson (2009), en su estudio realizó un seguimiento a 9 Mujeres (21-24 años) de la I División de jugadoras de waterpolo femenino durante su última temporada y los primeros nueve meses de su retiro, con el propósito de examinar sus experiencias y a la vez determinar los efectos de la identidad deportiva en el ajuste emocional durante el retiro. Lo que se halló 
fue que la identidad deportiva alta es un factor debilitante en el proceso del retiro. Las mujeres que llevaban más años como deportistas se aferraron mucho más a su identidad deportiva, de manera que el trauma experimentado fue mayor. Frente a ello, estas mujeres utilizaron diversas estrategias para poder sobre llevar esta situación, como el apoyo social, el ejercicio continuo y la búsqueda de un nuevo enfoque. Asimismo, ellas mencionaron que el hecho de compartir sus sentimientos en todo el proceso fue algo favorable.

\subsubsection{Transición a una carrera profesional alternativa}

En una investigación, realizada por Pallarés, Azócar, Torregrosa, Selva y Ramis (2011), sobre Modelos de trayectoria deportiva en waterpolo y su implicación en la transición hacia una carrera profesional alternativa, se plantearon tres modelos:

El modelo lineal, en el que el deportista tiene como primera opción el deporte y se observa que su identidad está directamente relacionada su disciplina deportiva, de manera que deja de lado todas las actividades que no estén relacionadas con su actividad. Además, ellos consideran su deporte como un trabajo porque reciben una paga y diversos beneficios que le permiten subsistir. Asimismo, para este tipo de trayectoria es necesario el apoyo, tanto del entrenador como de la familia, ya que sin ellos no sería posible el desarrollo de la misma y así reducir las posibles emociones negativas. Es en este modelo, que el retiro se percibe como algo abrupto y en muchas ocasiones el retiro llega a ser involuntario. 
El modelo convergente, habla sobre los deportistas que tienen como primera opción al deporte y buscan trabajos compatibles con la práctica deportiva, siempre y cuando los horarios le permitan continuar con su disciplina. Se suele observar que estos deportistas no tienen estudios superiores, puesto que para este modelo la prioridad es el deporte. Asimismo, se encontró que la identidad deportiva es inferior al modelo anterior, ya que, aunque prioricen el deporte, igual desarrollarán otras áreas de su vida fuera del deporte.

Por último, el modelo paralelo, es en el que el deportista compatibiliza la formación superior con su práctica deportiva. Es probable que al momento de entrar al mundo laboral estos deportistas se dediquen a trabajos relacionados con sus estudios. En cuanto a la identidad deportiva, se encontró que era mucho menor en comparación a los otros dos modelos, ya que el deportista no prioriza su vida en base al deporte que realiza, sino que además construye lazos sociales externos al deporte.

\subsection{Servicios tras la retirada}

En un estudio realizado por Duque-Ingunza y Dosil (2017), los participantes opinaron sobre los servicios que les hubiera gustado recibir mientras competían y durante la transición. Entre ellos se encontró: información sobre trabajo y estudio, recibir ayuda para desarrollarse en una nueva carrera o interés, información sobre cómo manejaron la retirada otros deportistas, aprender a trasladar las habilidades psicológicas a una nueva carrera profesional o interés, reunirse con otros deportistas 
retirados, lineamientos y guía para mejorar la autoconfianza y competencia, programas fisiológicos y dietéticos de desentrenamiento y ayudas económicas.

\subsubsection{Apoyo psicológico durante el retiro}

Según Cócola (2010) el trabajo del psicólogo deportivo no es del todo comprendido, sobre todo en un país como el nuestro en que la psicología deportiva no tiene una fuerte participación. En diversas ocasiones el psicólogo deportivo es confundido con un "mago", que puede transformar una situación de un momento a otro, trayendo victorias milagrosas.

Asimismo, Córdova (2006) refiere que el psicólogo deportivo tiene una variedad de funciones, orientadas al trabajo con el deportista y con las otras

personas implicadas en el ámbito deportivo. El trabajo en conjunto con el preparador físico es necesario, sobre todo en temas de aprendizaje y desarrollo motor, aspectos sensoriales y perceptivos, ajuste de cargas físicaspsicológicas, técnicas de motivación. De manera, que se debe lograr un trabajo interdisciplinario del psicólogo con los otros especialistas involucrados en el entrenamiento.

De igual manera, al ser la etapa del retiro un proceso transitorio, se requiere, al menos, dos líneas de trabajo por parte del Psicólogo Deportivo. En primer lugar, en el aspecto preventivo, se busca ayudar a formar un plan a futuro tanto a nivel personal como profesional durante el periodo en el que el atleta todavía se encuentra en actividad. En segundo lugar, en el aspecto de afrontamiento, se le debe brindar al deportista asesoramiento e intervención 
personal, de manera que no se presenten problemas durante el periodo de ajuste al nuevo contexto (García-Naveira, 2010).

\subsubsection{Programa de asistencia de carrera}

En vista de las características que presentaban los deportistas al momento del retiro, se vio la necesidad de ayudar a éstos en la coordinación de su participación en el deporte con otro tipo de actividades, y surgió la preocupación para prepararlos para la transición de carrera. Dando lugar a diversos programas de asistencia de carrera desarrollado en diferentes países; por ejemplo, el Olympic Athlete Centre (Canada), Career Assistance Program for Athletes (EE.UU.), Retire Athlete (Holanda), etc. Los programas de asistencia de carrera son definidos como una integración de talleres, seminarios, módulos educativos, asesoramiento individual y/o oferta de una red de referencia individual o servicios multidisciplinarios orientados hacia grupos de apoyo a los deportistas en relación a su participación a nivel deportivo, desarrollo de aspectos en su estilo de vida, educación y formación profesional (Wylleman et al., 2004). De esta manera, los programas adoptan intervenciones preventivas con el afrontamiento en crisis e intervenciones clínicas, si son requeridos. La población que abarca los programas de carrera son: deportistas junior, estudiantes deportistas, deportistas de élite senior y deportistas retirados o en retirada (Carlin y Garcés de los Fayos, 2012).

Asimismo, en una investigación realizada en Brasil se llegó a la conclusión que era necesario desarrollar programas de jubilación que tengan como 
objetivo principal capacitar a los deportistas en la transición de la carrera, y así a manejar mejor ese momento. Utilizando estos programas al inicio de la carrera para reducir la ansiedad con respecto al futuro; siendo conscientes de su importancia para que el deportista experimente una integración positiva a la vida post deportiva, previniendo posibles desordenes emocionales (Cury et al., 2008),

\subsubsection{Estrategias de soporte a los deportistas}

Los psicólogos Alfermann y Stambulova (2007) en su estudio, informaron que las estrategias de afrontamiento que fueron más utilizadas por los deportistas retirados durante su proceso de adaptación y que resultaron más eficaces fueron: encontrar otra actividad de interés, mantenerse ocupados, continuar en actividad física (entrenando y ejercitándose), conversar con alguien que los escuche, continuar en contacto con el deporte o con sus compañeros de equipo. Asimismo, otro tipo de estrategias sugeridas para facilitar la adaptación son: métodos cognitivos de manejo de estrés, la restructuración cognitiva, la expresión emocional, las imágenes mentales, tener un diálogo positivo de sí mismo y entrenamientos en relajación.

Por otro lado, según Stambulova (2010), el proceso de asesoramiento debe resaltar las cualidades del deportista, y que cómo estás son transferibles y pueden ser utilizadas en otros contextos. Esta técnica puede ser usada como un instrumento preventivo. Asimismo, es necesario intervenciones concretas durante y después del final de la carrera deportiva, ya que hay una gran 
posibilidad de desarrollar dificultades para enfrentar la pérdida de estatus, incluso después de adoptar nuevos roles, tanto a nivel profesional, social y familiar. Es de esta forma, que se hace evidente la necesidad de un apoyo psicológico y la formación profesional, como un medio que puede facilitar el proceso de transición de carrera (citado en Carlin y Garcés de los Fayos, 2012).

Finalmente, en base a diversas investigaciones y estudios, Carlin y Garcés de los Fayos (2012) proponen algunas intervenciones complementarias, de manera que sean estrategias de soporte para los deportistas durante la transición. En primer lugar, se plantea ayudar a nivel económico mientras que el deportista se encuentra buscando un trabajo apropiado. En segundo lugar, realizar seminarios que traten temas relacionados al ajuste, previo al retiro de los atletas, contando con la colaboración de ex deportistas. De esta forma, pueden compartir sus experiencias y consejos. En tercer lugar, formar un centro de recursos que busque guiar y brindar a los atletas el servicio que necesiten. Éste podría ofrecer seminarios, talleres y apoyo psicológico. En cuarto lugar, sería importante abrirles la posibilidad a los deportistas de que puedan contribuir en el sistema deportivo con su experiencia, ya que cuentan con conocimientos específicos que podrían ser útiles para los centros de entrenamiento. En quinto lugar, buscar que las organizaciones deportivas fomenten relaciones contractuales con los deportistas. Además, realizar programas, mientras el deportista aún se encuentre en actividad, sobre habilidades sociales. Y, por último, siempre tomar en cuenta las 
recomendaciones que hacen los deportistas para poder sobrellevar el retiro de una manera más saludable.

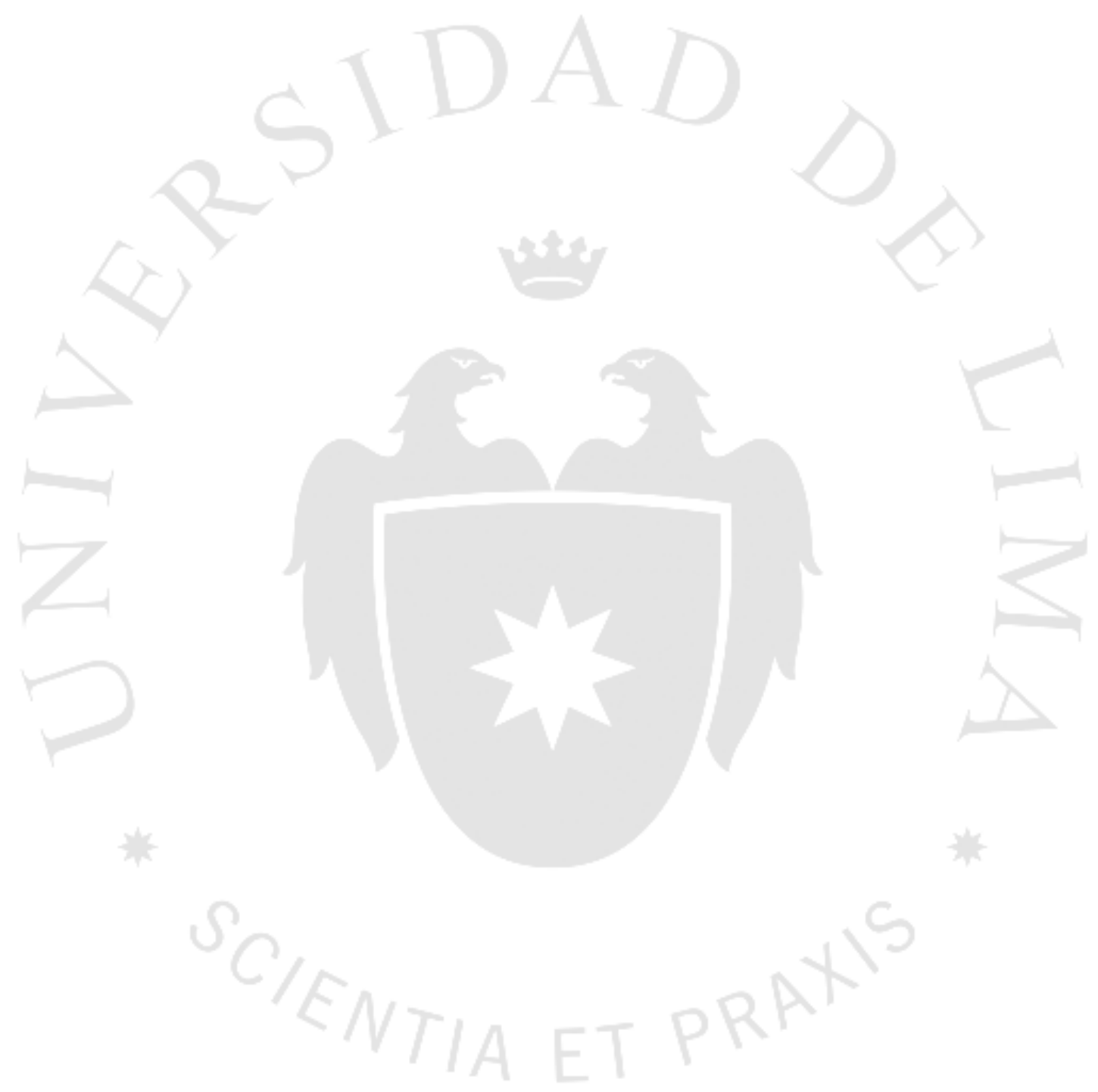




\section{CAPÍTULO III: OBJETIVOS}

3.1 Describir la experiencia personal del retiro desde la perspectiva de un deportista de alta competencia.

3.2 Identificar las emociones de los deportistas de alta competencia al momento del retiro.

3.3 Identificar las ideas y pensamientos asociados al retiro que tuvieron los deportistas al enfrentar dicha etapa.

3.4 Identificar las repercusiones que tuvo el retiro en los diferentes aspectos de la vida del deportista de alta competencia.

3.5 Identificar factores personales que favorecieron o no su adaptación durante la etapa de retiro.

3.6 Identificar factores externos que favorecieron o no su adaptación durante la etapa de retiro. 


\section{CAPÍTULO IV: MÉTODO}

\subsection{Tipo de investigación y Método}

La presente investigación consistió en un estudio cualitativo, al ser un tema nuevo de estudio en el Perú, recomendándose hacer este tipo de investigación cuando hay poca exploración acerca del tema. Asimismo, según Denzin y Lincoln (2005), esta investigación sería de tipo cualitativo, ya que se basó en la búsqueda de interpretaciones a través de entrevistas y conversaciones. Frente a ello, la investigación se enfocó en describir la experiencia de deportistas de alto rendimiento retirados que residen en Lima; buscando explorar el punto de vista de los participantes en un ambiente natural, relacionado a su contexto.

Por otro lado, el estudio es de nivel exploratorio, puesto que, a nivel nacional, es un tema al que se le ha dado poca importancia y que no ha sido estudiado a profundidad. De manera, que se buscó ampliar el conocimiento del tema, familiarizándose con este fenómeno relativamente desconocido: la experiencia personal del deportista de alta competencia durante la etapa de retiro (Cauas, 2015).

Con este fin, la investigación buscó aportar a la compresión del significado que tiene el retiro para los deportistas de alta competición que residen en Lima. Asimismo, tiene un alcance descriptivo para conocer, de manera consistente y coherente las características más importantes del fenómeno sometido a análisis. En base a lo mencionado, se planteó un estudio que permitiera conocer y describir la 
experiencia de los deportistas de alta competición luego de culminada su etapa deportiva (Verd y Lozares, 2016).

Por otro lado, se utilizó una metodología fenomenológica, de manera que se usaron abordajes naturalísticos y cualitativos para comprender inductiva y holísticamente la experiencia de los deportistas de alta competición que se encuentran en etapa de retiro, amoldándose al contexto específico de cada uno de ellos. Es decir, que no se estudió una realidad "objetiva y externa", que fuese igual para todos, sino una realidad cuya esencia depende del modo en el que lo vivencia el sujeto, siendo una realidad única y propia de cada deportista (Martínez, 2013).

\subsection{Participantes}

El presente estudio se realizó con 10 participantes. La población seleccionada estuvo conformada por deportistas de alto rendimiento, que se ofrecieron voluntariamente a participar; de manera que se les hizo una invitación y solamente los deportistas que quisieron compartir su experiencia y ser parte de la investigación fueron entrevistados (Palomino, Peña, Zevallos y Orizano, 2017). Asimismo, es un tipo de muestra de caso tipo, ya que se necesitó la opinión de deportistas con experiencia en el tema; y solo es posible acceder a esta clase de información con atletas de alta competición que hayan pasado por el proceso de retiro. Este tipo de muestra es frecuente en estudios cualitativos y exploratorios, de manera que se halle información precisa y rica, siendo posible profundizar en el tema para el fin requerido (Hernández, Fernández y Baptista, 2014). 
Cabe precisar que los deportistas de alta competición retirados que participaron fueron 5 hombres y 5 mujeres, de diversas disciplinas deportivas (solo se consideraron los deportes que involucran actividad física), que residen, actualmente, en Lima. La edad del grupo abarcó un rango entre 26 y 78 años, siendo 51 años la edad promedio. Por otro lado, el promedio de duración de la carrera deportiva fue de 10 años. Asimismo, el rango de edad en el que los deportistas se retiraron estuvo entre los 16 y 38 años, siendo 27 la edad promedio de retiro.

Por último, el tamaño de la muestra se determinó a través del punto de saturación, es decir, que cuando ya no se obtuvo nueva información de las entrevistas y ésta comenzó a ser redundante, se alcanzó el número de participantes necesarios para la investigación (Blanco y Castro, 2007).

Tabla 4.1.

Variables Sociodemográficas

\begin{tabular}{|c|c|c|c|c|c|}
\hline Edad & Sexo & Disciplina Deportiva & $\begin{array}{l}\text { Duración de } \\
\text { carrera }\end{array}$ & $\begin{array}{l}\text { Edad de } \\
\text { retiro }\end{array}$ & Ocupación actual \\
\hline 52 & $\mathrm{M}$ & Fútbol & 16 años & 33 & Entrenador \\
\hline 28 & $\mathrm{~F}$ & Natación & 14 años & 16 & Ama de Casa \\
\hline 26 & $\mathrm{~F}$ & Natación & 16 años & 21 & Entrenadora \\
\hline 56 & $\mathrm{~F}$ & Vóley & 17 años & 31 & Comentarista deportiva \\
\hline 35 & M & Box & 4 años & 28 & Entrenador \\
\hline 66 & M & Box & 10 años & 22 & Entrenador \\
\hline 72 & M & Fútbol & 23 años & 38 & $\begin{array}{l}\text { Asistente de } \\
\text { administración }\end{array}$ \\
\hline 50 & $\mathrm{~F}$ & Vóley & 22 años & 36 & Entrenadora/Repostería \\
\hline 50 & $\mathrm{~F}$ & Natación & 8 años & 18 & Call center \\
\hline 68 & M & Fútbol & 20 años & 34 & $\begin{array}{c}\text { Comentarista } \\
\text { deportivo/Entrenador }\end{array}$ \\
\hline
\end{tabular}




\subsection{Técnicas de recolección de información}

La técnica que se utilizó para la recolección de información fue la entrevista, siendo una práctica más íntima, adoptando la forma de un diálogo, facilitando obtener información personal sobre la situación que vive, y así se estructuró para obtener todos los datos necesarios. Para el presente estudio se utilizó la entrevista semiestructurada, ya que gracias a su carácter flexible, le permitió al entrevistador conducir el diálogo acorde a la situación. Para ello, se basó en una guía de preguntas, pero tuvo libertad de introducir preguntas adicionales para obtener mayor información de algún tema (Díaz, Torruco, Martínez y Varela, 2013).

Para la entrevista se formuló alrededor de treinta preguntas, las cuales buscaron indagar cómo experimentó el atleta de alta competición el pase al retiro, cuáles fueron los pensamientos que lo abordaban, cómo se sintió al dejar atrás una parte importante de su identidad. Asimismo, qué tipo de actividades realizó al dejar la vida deportiva, si le fue fácil adaptarse a su nueva rutina o si le costó tanto a nivel físico como psicológico. Frente a ello, para verificar la relevancia y adecuación de las preguntas al contexto determinado se recurrió a la opinión de tres expertos, que se encargaron de verificar la calidad de las preguntas elaboradas y determinaron si eran las adecuadas para extraer la información necesaria durante la entrevista.

\subsection{Procedimiento de recolección de información}

El procedimiento para recolección de datos de la presente investigación consistió, en primer lugar, en convocar a cada uno de los participantes de manera individual y por vía telefónica. Los deportistas que decidieron participar del estudio fueron 
citados, fijando así la fecha, hora y el lugar de la entrevista, para que pudiesen brindar su testimonio.

El día de la entrevista se le entregó al atleta, antes de iniciar, un consentimiento informado, en el que se le explicó, brevemente, en qué consistía la investigación y la importancia de la información que fuese brindada; de manera que se solicitaba que sus respuestas fueran lo más honestas posibles. Asimismo, se le aseguró que todos aquellos datos que fuesen brindados quedarían bajo estricta confidencialidad. Una vez firmado el consentimiento, se procedía a iniciar la entrevista, tomando en cuenta las condiciones del ambiente que podrían llegar a distorsionar las respuestas de los participantes.

\subsection{Estrategias de análisis de información}

En primer lugar, buscando obtener la mayor cantidad de información y que ésta quede registrada sin omitir ningún dato clave para la investigación, se elaboró una bitácora de análisis. En las que se anotó información acerca de todas las actividades realizadas (método); asimismo, se registraron las ideas, conceptos, significados, categorías e hipótesis que fueron surgiendo. De manera que esto sirviese para que otros investigadores pudieran replicar el trabajo y buscar generalizaciones.

Seguidamente, se requirió que toda la información recogida a través de las entrevistas a los atletas se encontrasen bien organizados, para que así la información resultase manejable para luego ser analizada. 
No obstante, para poder interpretar más minuciosamente los datos recogidos, se transcribieron las grabaciones de las entrevistas, y nuevamente se examinó la información recogida. Luego se procedió a leer repetidamente las partes de las entrevistas transcritas, puesto que así se pudo seguir la pista de temas encontrados dentro de la información obtenida y permitió realizar interpretaciones e ideas acerca de la vida y características psicológicas de los deportistas de alta competencia en su etapa de retiro. Es así como se buscó conocer la esencia de las ideas mencionadas por las atletas; asimismo, qué tono tuvieron dichas ideas; así como, qué es lo que estaban indicando estos datos. Posteriormente, se procedió a organizar con precisión la información, mediante determinado criterio (Rodríguez y Valldeoriola, 2012).

Para la realización del análisis de información, el proceso esencial consistió en agrupar los datos en bruto en categorías, luego se comparó las categorías entre sí para englobarlas en temas y buscar posibles vínculos. Asimismo, se describió las experiencias de los deportistas, comprendiendo a profundidad el contexto que los rodea; y en base a los datos recogidos, se los interpretó y evaluó, relacionándolos con la teoría fundamentada. De tal manera que las interpretaciones surgidas en el proceso de investigación estuviesen asociadas al planteamiento del problema. El análisis implicó estudiar cada parte de los datos en sí mismos y en relación con los demás, buscando hallar semejanzas y diferencias entre cada una de las entrevistas; de manera que dependiendo de lo que los deportistas revelaron, el análisis se iba viendo moldeado. 
Por último, como se menciona líneas arriba, toda la información se analizó buscando cualidades similares, de manera que se englobaron en una misma categoría, y cuando una información no encajaba dentro de alguna categoría, se procedía a generar una nueva categoría para ella. De esta manera, a cada categoría se le asignó un código, ya que de esta forma los datos brutos se transformaron sistemáticamente en unidades de análisis; y así se pudo tener una descripción precisa de las características de su contenido (Andréu, 2002). Finalmente, una vez llegado al punto de saturación se dio el análisis por concluido; para ello se debió asegurar que no se encuentren inconsistencias o falta de información que dificultase el entendimiento del problema planteado, pues sino se debía continuar recogiendo mayor información a través de nuevas entrevistas.

Cabe resaltar que como parte de los procedimientos de rigor metodológico, para asegurar la credibilidad del estudio, utilizando de base el planteamiento de Guba (1989), se realizó la devolución de resultados obtenidos en el estudio, en el que se les pidió a 3 participantes que revisen las categorías y su contenido, por medio de una sesión de entrevista individual; de manera que den fe que la información no hubiese sido manipulada y que los datos reflejen la información que había sido brindada por ellos. Asimismo, se les brindó un resumen de la información analizada, con el propósito de asegurar que la información no hubiese sido mal interpretada y que refleje lo que en realidad pretendían comunicar. 


\section{CAPÍTULO V: RESULTADOS Y DISCUSIÓN}

A través de 10 participantes entrevistados se ha logrado recolectar información pertinente para la investigación cualitativa, de manera que los atletas han podido describir su experiencia frente al retiro. En base a ello, se realizó el análisis agrupando los comentarios que fuesen similares, permitiendo la construcción de las siguientes categorías: 1) El significado personal del deporte. 2) Las causas del retiro. 3) El significado personal del retiro. 4) Reacciones frente al retiro. 5) El impacto del retiro. 6) Factores que condicionan la adaptación. 7) Satisfacción Actual.

Para una mejor comprensión de los resultados, se incluye un resumen del cuadro de Categorización de la información analizada, en el Apéndice 7.

\section{Significado Personal del deporte:}

La primera categoría, está compuesta por cuatro subcategorías: la identidad, el éxito, la satisfacción y la dedicación.

\section{a. Identidad}

Se observa que el deportista construye un fuerte vínculo con su disciplina deportiva, al considerarlo como parte fundamental en su vida. De manera que se forja no solo una estrecha relación emocional con la disciplina, sino una identidad deportiva:

“Era mi vida, bueno hasta ahora sigue siendo mi vida, por eso sigo enseñando. Yo no veía mi vida sin la natación para nada... Si era parte de mi identidad, me pueden preguntar ¿quién eres? Y yo voy a decir que soy nadadora”. (Nadadora, 26 años). 
"Es mi vida, si volviera a nacer volvería a ser voleibolista.... Al inicio no sentía que era parte de mi identidad, pero cuando... me obligaron a retirarme..., sí me di cuenta de que se estaban llevando algo de mi." (Voleibolista, 56 años).

"Me sentía ubicado, me iba bien, sentía que pertenecía ahí. Sí claro que era parte mi identidad." (Boxeador, 35 años).

“...Naci para el futbol, mi vida era el futbol.” (Futbolista, 72 años).

Los deportistas consideraron a la identidad deportiva como la totalidad de su identidad. Tal como lo señaló Williams (1991), en los atletas se da una fuerte identificación con su disciplina desde que inician la práctica, en la infancia, y va intensificándose con el pasar de los años. Sin embargo, la identidad exclusivamente deportiva genera mayor malestar emocional durante el retiro, convirtiéndose en un factor debilitante en la transición. Como consecuencia, el retiro puede llegar a ser una experiencia traumática; provocando dificultades psicológicas, como sintomatología depresiva y ansiosa. Esto se observa con más frecuencia en los deportistas que llevan más años practicando la disciplina, ya que se aferran con mayor fuerza a su identidad deportiva (Richardson, 2009; Cury et al., 2008; Giannone, 2016). Frente a ello, se evidencia que una exclusiva identidad deportiva se convierte en un factor que interviene durante el retiro, ya que dificulta el proceso de adaptación, llegando a generar, en algunos casos, que el retiro sea vivido como un duelo.

\section{b. Éxito}

El buen desempeño trajo consigo triunfos y reconocimientos; frente a ello, esto que en un inicio fue un objetivo, se convierte en una parte fundamental de su carrera (observándose 
más en los deportes más populares, como el futbol); asimismo, la retribución económica recibida jugó un aspecto importante en la concepción del éxito; contribuyendo en la consolidación de una imagen positiva de sí mismos:

"Yo vivía del futbol... todo lo que tú ves en la TV para mí era un sueño cumplido... Sentía una felicidad enorme de poder lograr que tu pasión no solo sea una satisfacción personal, sino que económicamente te retribuía." (Futbolista, 52 años).

"Siempre estuve entre las primeras, y a mi retiro de la selección de Perú fui la mejor jugadora del mundo, olímpica, de ahí me fui a jugar el campeonato mundial, al Sudamericano y equipo de Club Sadiem de Sao Pablo, campeona mundial de Clubs, creo que fui la única jugadora en el extranjero." (Voleibolista, 56 años).

"Si no hubiera sido por el futbol nadie me conocería... Para mí ha sido un abre puertas, ventanas, techos y todo... Son dos metas: una, vestir la camiseta del Perú y dos, jugar en el extranjero. Además, que te pagan una barbaridad." (Futbolista, 72 años).

El valor que los deportistas le dan al éxito, como se verá en la categoría "Impacto", se convierte en un elemento que afecta a nivel personal (mayor malestar emocional), pudiendo llegar a afectar la autoestima. González y Bedoya (2008), mencionan que muchas veces el reconocimiento social termina teniendo una fuerte influencia sobre la experiencia del retiro, ya que el prestigio, la atención del medio y el reconocimiento cambian drásticamente una vez que el deportista se retira. De manera que si el atleta ha basado su valor personal entorno a los aplausos, al éxito, elogios, etc. el periodo de retiro podría llegar a ser más difícil, apareciendo el temor a dejar de ser reconocido y valorado. 


\section{c. Satisfacción}

El deporte que practicaban fue un medio para mejorar la situación económica, y en algunos casos fue un medio para salir de la pobreza, brindándoles una oportunidad para optimizar su calidad de vida y la de su familia. Los atletas, refieren un fuerte sentimiento de gratitud hacia la disciplina deportiva, porque le atribuyen los logros alcanzados:

“El haber logrado ser futbolista profesional me permitió ayudar a mi familia... Mi

ilusión ... siempre fue sacar a mi familia adelante, y... lo logré.” (Futbolista, 52 años)

"Hay sueños que tiene todo niño, y el mío era salir adelante, hacer algo diferente, salir de la pobreza... con el vóley voy a hacerle la casa a mi mamá... Si yo no hubiera jugado vóley, hubiera sido 4 letras, me hubieran metido al narcotráfico porque yo vivía en un ambiente muy terrible, muy cruel, y a veces tienes la necesidad. Porque yo veía que mi mamá lloraba que no tenía... Para mí, el vóley, fue lo mejor que me paso en la vida." (Voleibolista, 56 años).

Asimismo, el destacar en la disciplina deportiva los lleva a sentirse "únicos", generando en ellos un fuerte sentimiento de orgullo, comprendiendo este término como el sentimiento positivo de satisfacción frente a sí mismo:

“Haber logrado, haber cumplido ese sueño de niño, ser futbolista profesional para mi es mi gran orgullo... Sentía una felicidad enorme de poder lograr que tu pasión sea una satisfacción personal." (Futbolista, 52 años). 
"En el momento en que jugaba yo era admirada, ya no era la flacuchenta, la fea, la tallarín, dentro de la cancha yo era alguien especial... comencé a pensar que esta era la forma de demostrar que no había racismo en el deporte... Yo voy a ser la mejor jugadora del mundo". (Voleibolista, 56 años).

En este sentido, la sensación de bienestar que tuvieron durante la carrera deportiva se convirtió en un aspecto que favoreció la adaptación al retiro. Tal como lo señalan DuqueIngunza y Dosil (2017), la consecución de objetivos deportivos se relaciona con un ajuste positivo al retiro, ya que los sentimientos de logro fomentan un proceso de transición más armonioso. Además, se observa que el recuerdo de esta sensación, continúa generando en el presente emociones positivas, como la gratitud, el orgullo y la alegría.

\section{d. Dedicación}

Para dedicarse exclusivamente al deporte y alcanzar los resultados esperados los deportistas tuvieron que renunciar a determinadas actividades (sociales y/o académicas). Esto no era considerado un sacrificio, sino una decisión voluntaria para alcanzar sus objetivos:

“...Me dedicaba de lleno al fútbol, era mi vida, estaba dedicado completamente...

ingresé a la San Martín a estudiar derecho, lo dejé por el futbol... todo iba dejando en parte por el tiempo que no me daba y bueno porque mi cabeza estaba en el futbol... Claro que tiene sus sacrificios, no todo es felicidad..., bueno nada es perfecto, pero en la balanza pesa más que haces la actividad que te apasiona y encima te ayuda a vivir." (Futbolista, 52 años).

"Había sacrificios que uno tenía que hacer, pero cuando uno dice sacrificio, yo no me arrepiento. Era un sacrificio dulce, rico porque al día siguiente si yo dormía bien, jugaba 
bien... Dejé la universidad, me costó mucho porque quería ser abogada." (Voleibolista, 56 años).

En este contexto para alcanzar el desempeño deseado, el deportista debía entrenar intensiva y constantemente, convirtiéndose en una actividad exclusiva y en algunos casos excluyente, relegando otras áreas de su vida, como, por ejemplo, el aspecto académico. De manera, que concluyen la etapa deportiva sin una carrera profesional que los respalde (Wylleman y Lavallee, 2003; y García-Naveira, 2010). Esto puede convertirse en un factor que dificulta el proceso de transición, como se detallará más adelante.

\section{Causas del Retiro:}

Esta categoría está compuesta por dos subcategorías: Retiro voluntario y Retiro forzado.

\section{a. Retiro voluntario}

En base a los testimonios se observa que el retiro puede darse en dos etapas distintas, mientras los atletas se encuentran en la plenitud de su carrera y cuando ya se encuentra en el ocaso de ésta. En cuanto a los deportistas que se encontraban cerca al final, podemos observar que unos tomaron la decisión de retirarse debido a la impuntualidad del pago, lo que deterioraba la relación con los directivos de los equipos y generaba insatisfacción, restándole disfrute a la práctica deportiva. Por otro lado, hubo atletas que se retiraron porque querían realizar otras actividades, puesto que su ciclo como deportistas de alta competencia había llegado a su fin, siendo momento de iniciar nuevos proyectos:

"Decidí retirarme por el abuso que había con los futbolistas, ya en los últimos años había una informalidad que la gente no pagaba, no te respetaba los contratos, entonces esos últimos años de mi carrera no la pasé bien porque todo era pleitos y yo tenía una 
personalidad muy fuerte y me paraba peleando con los dirigentes. Hubo momento en que ya no me quería ningún club porque me paraba peleando... Tampoco quería estar peleándome más, ya no disfrutaba estar en un plantel porque más me la pasaba peleando que disfrutando el partido." (Futbolista, 52 años)

"Me retiré por un tema de estudios y de edad, ya había llegado a mi edad límite en esa época. Además, ya me tocaba empezar la universidad y definitivamente no iba a poder estudiar si es que continuaba con el ritmo de la natación”. (Nadadora, 50 años)

En cuanto al participante que se retiró en la cumbre de su carrera, esto se debió a la exigencia deportiva, ya que llegó a un punto de saturación en el cual sentía mucha presión, puesto que el ritmo de vida no le permitía disfrutar de otras actividades acorde a su edad:

"En 5to de media les dije a mis papás: ya no aguanto. Me aburrí y dije: hasta acá no más... Aburrimiento, me harté. Me harté, tenía mucha presión. El Comité Olimpico venía y me decía: tienes esta beca, te vamos a dar plata. Salía en los periódicos: la promesa para las olimpiadas. Era por un lado paja, pero por otro lado mucha presión. Y para una chica de 14, 15 años es bastante presión ... Era demasiado, llegó un punto en que iba y no quería meterme a la piscina. Llegó un punto en que ya no quería competir, y eso ya era grave. Poco a poco empecé a aburrirme porque ya crecía, y mis amigas del colegio podían salir y yo no... pijamadas una que otra, quinces uno que otro, no fui a mi viaje de promoción porque tenía que entrenar porque tenía un mundial... Estaba peleada con la natación, sentía que me había quitado un montón de cosas que el resto de gente sí normalmente podía vivir... "Estoy harta, déjenme en paz, déjenme de decirme que soy la mejor, que 
tengo que ir a entrenar, que puedo ir a la olimpiada...Para mí fue: yo no voy a hacer lo que mis papás me digan, fue rebeldía y aburrimiento... “ (Nadadora, 28 años).

Según Carlin y Garcés de los Fayos (2012) el retiro voluntario contribuye a un proceso de transición más suave; sin embargo, como se verá en la categoría "Impacto", en el presente estudio el proceso de transición fue en ocasiones igual de difícil que el retiro forzado. Cury et al. (2008) indica que uno de los motivos para el retiro voluntario es cuando el deportista está psicológicamente cansado y el ambiente deportivo se desgastó; esto se ve en dos de los testimonios, en el que los atletas prefirieron apartarse del campo deportivo al sentirse saturados y al perder el disfrute de la actividad. Frente a ello, se observa que a pesar que los participantes refirieron que el retiro fue voluntario, se puede inferir que fueron las circunstancias adversas las que los condujeron indirectamente a tomar la decisión de retirarse, puesto que existen indicios en su discurso que evidencian arrepentimiento frente a la decisión tomada: "Yo me arrepiento de haberme retirado. Creo que es una de las peores decisiones que he podido tomar." Por otro lado, Roffé (2000) refiere que los deportistas se retiran voluntariamente al tomar consciencia que su rendimiento está en declive, como mencionó uno de los participantes, que decide retirarse al darse cuenta que su rendimiento físico con la edad había disminuido. Teniendo en cuenta lo mencionado, la diferencia entre quienes toman la decisión de retirarse libremente y quienes se ven influenciados por las circunstancias, es que la primera no produjo niveles elevados de malestar emocional y facilitó el proceso de transición, en comparación con la segunda, que fue un proceso doloroso y difícil de enfrentar. 


\section{b. Retiro Forzado}

Dentro de esta subcategoría, se observa que los atletas fueron forzados a retirarse por factores físicos que les impedían continuar con la realización de la actividad física, o por factores externos a los deportistas que los obligaron directamente a retirarse.

Dentro de los factores físicos, una de las participantes tuvo que retirarse por un embarazo inesperado y otra de las casusas fueron las lesiones acumuladas a lo largo de la carrera:

"Me retiro debido a que sali embarazada... Me acuerdo de que competí hasta los 4 meses porque el doctor me dio permiso, pero de ahi tuve que dejarlo. ” (Nadadora, 26 años).

"Mi rodilla dijo: hasta acá. Yo tengo una rodilla casi de 90 años. El doctor me dijo: mínimo unos 10 años no puedes hacer nada. Yo no tuve opción, tuve que hacerlo." (Voleibolista, 56 años).
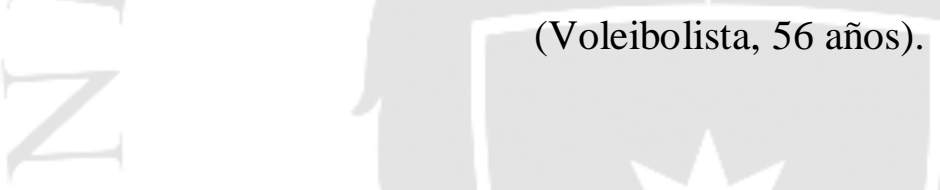

En cuanto a los factores externos, en unos casos, el plantel directivo tomó la decisión de retirar al atleta. Por otro lado, el aspecto económico forzó al deportista a dejar la actividad deportiva y buscar un trabajo más rentable:

"Yo me sentía en condiciones de poder jugar y alargar un poquito más mi carrera, pero los directivos me dijeron: ya solo juega hasta este año. Y yo soy de las personas que cuando no me quieren me voy." (Futbolista, 68 años).

"La decisión inicialmente no la tomo yo, me entero de que en la posición en la que jugaba habían convocado a otras jugadoras, entonces fue doblemente dolorosa porque fue como si me estuvieran invitando a retirarme en ese momento. O sea, nunca me dijeron que ya 
no estaba en el equipo, ni que me iban a botar, pero ya te das cuenta de que no estás en los planes del entrenador, entonces ya ahí sí o sí tienes que salir." (Voleibolista, 50 años).

"Un factor económico me obligó a retirarme. Ya tenía familia para ese entonces, 3 hijos. Me iba a ir a Estados Unidos, y mi mamá me decía: a qué te vas, a que te golpeen por un poco de dinero, no ven quédate acá y yo te doy trabajo de vendedor. De esa manera dejé el boxeo, y nunca más volví a entrenar seriamente." (Boxeador, 65 años).

En base a lo observado, González y Bedoya (2008) mencionan que el problema fundamental se encuentra en que son pocos los deportistas que realmente están preparados para afrontar esta etapa. Es por ello, que la dificultad para adaptarse, en ocasiones, está influida por la causa; siendo probable que ante un retiro forzado, los deportistas no tengan un plan para la etapa posterior. Asimismo, en investigaciones previas se halló que los atletas que cuentan con mayor libertad para decidir el final de su carrera, tienden a experimentar más emociones positivas, en comparación de los que fueron forzados a retirarse, observándose dificultad para adaptarse y altos niveles de estrés (Alfermann y Stabulova, 2007). En el presente estudio, los atletas que fueron forzados a retirarse se sintieron afectados a nivel emocional, ya que cuando la decisión llega de manera inesperada o por un factor o agente externo, el evento puede ser más doloroso; sin embargo, el proceso de adaptación no solo está influenciado por las causas, ya que existen recursos (personales y sociales) que influyeron, también, en la reacción y la forma de afrontar el retiro.

Por último, cabe señalar que lo hallado por González y Bedoya (2008) se asemeja a los testimonios, ya que las lesiones, la incompatibilidad entre estudios/trabajo y carrera 
deportiva, la propia decisión, la falta de motivación, la disminución del rendimiento y de los ingresos económicos, son las causas de retirada más frecuentes.

\section{Significado Personal del retiro:}

Esta categoría habla acerca de las creencias más profundas de los deportistas en relación al retiro, con un contenido emocional. Frente a ello, se observa que independientemente de la causa del retiro, la percepción subjetiva del atleta sobre este acontecimiento es un aspecto crucial para su adaptación posterior. La forma de ver el retiro está influenciada por el cambio de rol, sus afectos y el nivel de estrés al cual esté expuesto (Carlin y Garcés de los Fayos, 2012; Wylleman et al., 2004). De manera que en esta categoría se hablará sobre: pérdida, continuidad, equivocación y satisfacción.

\section{a. Pérdida}

Unos deportistas tuvieron la sensación de haber perdido algo muy importante, inclusive consideraron el retiro como un duelo. Siendo ésta una experiencia difícil de sobrellevar, ya que provocó una sensación de vacío, generando tristeza, inclusive querer dejar de vivir:

“" Es algo que lo llevas adentro siempre, hasta ahorita recuerdas: y por qué no hiciste esto acá, por qué no metí ese gol. Yo me voy a llevar eso a la tumba... El día que decidí retirarme me metí a mi cuarto y lloré toda la noche, porque es un golpe muy fuerte. Estás acostumbrado desde chiquito a realizar tu pasión... Y después, de la noche a la mañana, lo cortas y se va... pues es un golpe fuerte. Es una etapa de duelo porque es como que se acaba algo que llevas adentro, porque al final podemos ser entrenadores, dirigente, pero nuestra esencia es estar en la cancha y patear la pelota... Es una pérdida de algo de toda mi vida." (Futbolista, 52 años). 
"Horrible, horrible... mi retiro fue muy duro. El doctor me da la noticia de un momento a otro... no voy a volver a jugar... Me volvieron a operar para sacarme los clavos, yo entré con tal desesperación, desanimo total, que me abandoné. Cuando salí de la sala de operaciones no reaccionaba. El doctor le dijo a mi amigo: o tú haces algo o tu amiga se muere porque ella no quiere vivir... Recién ahí acepté que uno puede morir por algo o por alguien, y en este caso era el deporte. Yo entiendo que unos deportistas mueran alcohólicos, drogadictos, enfermos y ahora sé por qué... porque cuando te cortan algo que es parte de ti es muy duro de aceptar." (Voleibolista, 56 años).

"Es como un luto, los primeros meses es bien doloroso. De verdad yo sí necesité mucho apoyo de mi familia, y ni aun así. Para mí fue totalmente una pérdida. Dejar ir algo que para mí era mi vida, mi pasión. Algo que era parte de mi personalidad. Yo sí sentí que una parte de mí se moría... Fue lo mismo que me pasó... hace casi 4 años cuando murió mi mamá. Es exactamente el mismo sentimiento... de pérdida." (Voleibolista, 50 años).

"Una pérdida de una costumbre, de algo que es habitual, como si perdieras un trabajo. Sales y no puedes volver, donde tienes tu círculo de amigos, las personas que te atienden. ... somos mimados, la gente te reconoce...claro que es doloroso... Tienes que saber ubicarte, ya no eres parte del grupo...hay otros ahora ... es fuerte.” (Futbolista, 68 años). Los participantes refirieron haber experimentado una sensación de pérdida al dejar de lado una costumbre, los beneficios que conlleva ser un deportista de elite; así como, alejarse de sus compañeros de equipo. Sin embargo, el proceso de transición se dificulta cuando el 
participante ve el retiro como la pérdida de oportunidades para enmendar algo que "no pudo hacer" o hizo erróneamente durante la carrera, significando el retiro la imposibilidad de corregir el error, lo cual genera emociones de arrepentimiento y frustración. Asimismo, se observa que el dolor emocional aumenta, cuando hay una pérdida de identidad, experimentándola como un duelo. Esto guarda similitud con lo mencionado por González y Bedoya (2008), ya que, muchas veces, el retiro deportivo es percibido como un duelo, puesto que hay una sensación de pérdida por el abandono a la actividad que se ha realizado con gran dedicación por un periodo significativo de tiempo; llegándose a perder no solo un estilo de vida, sino también dejando atrás una identidad. Frente a ello, se evidencia que la pérdida de la identidad deportiva afecta negativamente al deportista, inclusive, como menciona uno de los participantes, disminuye el deseo por vivir.

\section{b. Transición: final o comienzo de una etapa}

Se encontraron deportistas que experimentaron el retiro como el final de una etapa, al ser parte natural del ciclo vital; siendo momento de asumir otras responsabilidades y roles:

"Yo creo que me retiré en buenos términos. No lo vi como un funeral... Yo lo vi como el

inicio de otra etapa... en realidad sí me costó retirarme, porque era algo que me encantaba hacer... pero era empezar una nueva etapa con mi hija... Sí me afectó un poco, pero de ahí lo vi del lado positivo, y dije: me esperan otras cosas. No me sentí mal con la decisión que tomaba, veía que podía tomar otro rumbo mi vida, no me veía truncada ni estancada..." (Nadadora, 26 años).

"Entraba en otra etapa de mi vida, donde tenía nuevas experiencias y otras responsabilidades. Sí lo extrañé, pero no diría que fue como que perdí algo...lo tomé como 
el continuar con mi vida en una nueva etapa. Era lo que tocaba ahora... Lo tomé como una culminación de una etapa que fue muy lindo y el inicio de otra. (Nadadora, 50 años). Se observa que los participantes sintieron tristeza, mas no fue experimentado como un evento catastrófico, ya que era lo que correspondía en ese momento para poder continuar con su vida. Esta forma de ver el retiro facilitó el proceso de transición, sintiéndose tranquilos frente a la decisión de retirarse. Carlin y Garcés de los Fayos (2012), refieren que actualmente el retiro no es visto como un evento singular, sino que es considerado un proceso, de manera que el deportista tiene un mejor ajuste. El fin de la carrera deportiva pasa a ser solo una fase más del proyecto vital, empalmando con nuevas actividades y planes. Asimismo, la mirada retrospectiva se ha complementado con la visión prospectiva, buscando que el deportista no solo se enfoque en sus logros pasados, sino que asuma conscientemente lo que está ocurriendo, y tenga una visión de sí a futuro. Así, su proyecto de vida no quedará estancado al retiro, siendo el comienzo de una nueva etapa, con nuevos planes y metas fuera del campo deportivo (Torregrosa, Sánchez y Cruz, 2003).

\section{c. Continuidad}

Los deportistas no vieron al retiro como el final de su vida deportiva, ya que continuaron practicando la disciplina deportiva a nivel recreativo o como entrenadores:

"Yo me retiré e hice... la gremiación y a la par puse una academia de fútbol... Yo todavía me considero deportista, siempre. Sigo haciendo ejercicios, salgo a correr al pentagonito, gimnasio, hago box y como sano, me duermo temprano, no tomo." (Futbolista, 52 años). 
"Me da chance de aportar al deporte... Entrenar gente y por ahí captar algún valor que quiera entrenar y poder explotarlo... Yo no llevé la antorcha olímpica, pero puedo ayudar a alguien a ... llevarla y eso me motiva." (Boxeador, 35 años).

$\mathrm{Al}$ retirarse los participantes continuaron en contacto con su disciplina deportiva, de manera recreativa o como parte del plante directivo; generando satisfacción al sentir que siguen en contacto con la disciplina deportiva; así como contribuyendo a su deporte, tal vez no de manera directa, pero a través de sus alumnos. Además, se observa que la identidad deportiva perdura a través del tiempo, considerándose deportistas aun así en el retiro. Esta visión les permitió a los atletas atravesar con mayor tranquilidad la etapa posterior a la carrera deportiva, ya que aún se sentían vinculados al deporte.

\section{d. Equivocación}

En la actualidad, unos participantes se sienten arrepentidos frente a las decisiones tomadas durante la carrera deportiva:

"Me da bastante rabia haberme retirado. Yo me arrepiento de haberme retirado. Creo que es una de las peores decisiones que he podido tomar. Es que fue inmadurez, cualquiera se puede aburrir. De repente uno no tiene la madurez necesaria para asumir... pero date cuenta del talento que tienes, y no dejarlo todo. Yo si me arrepiento totalmente, creo que es una de las peores decisiones que he podido tomar..." (Nadadora, 28 años).

"Nunca quise volver a ver partidos de vóley... ni nada porque me dolía tanto. Me echaba la culpa por no haber seguido las indicaciones de mis médicos. " (Voleibolista 56 años).

La decisión y el motivo de la retirada se convirtieron en una fuente de frustración y arrepentimiento. De manera, que esta forma de ver el retiro promovió la aparición de 
emociones negativas, que no facilitaron el proceso de transición; sin embargo, esto no impidió que el exatleta continuara con nuevos proyectos.

\section{e. Satisfacción}

Por último, en cuanto al significado que los deportistas le dan al deporte después de haberse retirado, algunos manifestaron estar satisfechos con los logros alcanzados durante su carrera deportiva, permitiéndoles experimentar emociones positivas:

"Me siento orgulloso de haber podido ser futbolista porque muchos chicos a veces no se atreven a soportar ese sacrificio, fuera fiestas, fuera chicas, fuera playa, porque les gana el placer, entonces yo me siento orgulloso de haber podido superar eso y haber alcanzado mi sueño, porque pocos chicos logran hacerlo o por esfuerzo o por capacidad... hay uno don que te dan y tienes que aprovecharlo." (Futbolista, 52 años).

"Yo creo que el reconocimiento que tengo a veces de la gente, me hace pensar y creer que el tiempo que me dediqué a lo que hice, lo hice bien. Entonces sientes una satisfacción que descubrí porque, como te decía, yo siempre he sido muy indiferente a las cosas. Yo jugué en Argentina los años 75 y 76... y en el 2015, mira cuántos años habían pasado, cerca de 35-38 años, voy con mi vecino y nos fuimos de viaje, nos subimos al taxi, y mi amigo me decía: compadre y usted cuando jugaba acá... Me preguntaba cosas. Y el taxista me miraba y manejaba, hasta que me dice: che peruano, discupá, ¿vos habés jugado al fútbol? Sí le digo. ¿Y para qué club jugó? Para el independiente. ¿Vos sos Percy? Sí le digo. Paró el carro, llamó a su hijo y le dijo: Mirá, aquí está Percy... Me sentí satisfecho 
(llora). Entonces pensé: algo bueno he hecho. Ya lo último, fue que la Confederación me premió en el 2015 por mi aporte al fútbol sudamericano." (Futbolista, 68 años).

Se encontró en una investigación que el ajuste positivo al retiro está relacionado con la consecución de objetivos deportivos, es decir que los sentimientos de logro y satisfacción promueven una transición más armoniosa, generando emociones positivas (Duque-Ingunza y Dosil, 2017). Ello se asemeja a los testimonios, ya que esta visión del retiro les permitió a los atletas continuar con su proyecto de vida, llevándose un grato recuerdo de su carrera deportiva. Asimismo, en la actualidad sienten que su aporte al deporte ha trascendido, ya que continúan siendo reconocidos y recibiendo el cariño de las personas.

\section{Reacciones frente al retiro}

Esta categoría busca conocer cómo reaccionó el atleta al ponerle fin a su carrera deportiva, describiendo las emociones y los pensamientos que aparecieron en ese momento.

\section{a. Emociones}

El retiro afectó emocionalmente a los participantes, para uno fue una experiencia cargada de emociones negativas, otros, por el contrario, experimentaron alivio. Asimismo, los participantes identificaron la intensidad de su emoción, ubicándola en una escala del 1 al 10; así como el tiempo que permanecieron afectados por ellas.

Entre las emociones negativas mencionadas se encontraron la ansiedad, tristeza, miedo, culpa, odio y frustración:

“Me volví muy ansiosa, depresión... Estaba totalmente inestable emocionalmente... Ansiedad 10, vivía ansiosa, por eso todo el día comía. En temas de depresión, tristeza, lo tapaba mucho en otras emociones, pero sí, por lo menos 9." (Nadadora, 28 años). 
“Frustración, odio. Es entre aceptar y no aceptar. Lloraba todos los días. Era obvio que yo sentía una pérdida y el dolor era tan grande por lo que había sido mi tabla de salvación. Nadie sabe el dolor que tiene un deportista cuando te obligan a retirarte, vivía recluida... Me duró años... Del 1 al 10, fue un 10 que sentí estas emociones... Me echaba la culpa por no haber seguido las indicaciones de mis médicos. " (Voleibolista, 56 años).

"Me daban ataques de pánico, como una angustia. Tuve que tomar pastillas para regularizarme... yo no sabía lo que era una depresión hasta que dejé de jugar vóley... Sentí mucha pena, mucho dolor. Sentí mucha ansiedad, mucha angustia. Tenía como que ataques de pánico. Sentía un dolor en el pecho, como un vacío... Esa ansiedad que no me dejaba dormir... Fueron como 3, 4 meses. Hasta ahora extraño, pero ya no es esa sensación de vacío, angustia, sino ya es algo más nostálgico ... Me costó muchísimo, fueron unos meses horribles, del 1 al 10, 10..." (Voleibolista, 50 años).

"Yo sentía que lo único que sabía hacer era jugar fútbol, entonces era el temor de ¡ahora qué voy a hacer?” (Futbolista, 72 años)

En cuanto a las emociones positivas, mencionaron sentir alivio y tranquilidad:

“Alivio, o sea sí fue alivio. La presión pudo más que las ganas.” (Nadadora, 28 años).

"Yo estaba tranquilo, mis emociones no fueron muy intensas, las controlaba." (Futbolista, 68 años). 
En base a los testimonios, se observa que las emociones mencionadas por los participantes guardan similitud con las referidas por Cury et al. (2008). En su investigación halló la predominancia de la tristeza y conformidad en cuanto a la decisión tomada en mayor cantidad; en menor cantidad felicidad tensión, miedo, depresión, rabia, resentimiento, culpa. Ninguno mencionó sentir desesperación; sin embargo, sí experimentaron distress. En el presente estudio, se observó la predominancia de la ansiedad y tristeza, siendo la segunda, en muchos casos, considerada como depresión. Otros sintieron odio, relacionado a la frustración de no poder continuar realizando el deporte que amaban; aparecen también emociones de culpa, miedo y nostalgia. Por otro lado, hubo quienes indicaron sentirse tranquilos al estar conformes con la decisión tomada. No obstante, los participantes no mencionaron haber sentido felicidad durante ese momento, a diferencia de lo hallado en la investigación de Cury et al. Frente a ello, se observa que mientras mayor espacio ocupó el deporte en la identidad del atleta, las reacciones emocionales fueron más negativas e intensas. Asimismo, la intensidad y la duración de las emociones variaron entre los participantes, dependiendo de los recursos de afrontamiento, a mayor efectividad, la intensidad y la duración eran menores.

\section{b. Pensamientos}

Cuando hablamos de los pensamientos, nos referimos a las ideas automáticas que aparecieron inmediatamente después de retirarse. Entre ellos se encontraron los de tipo: negación, injusticia, aceptación e incertidumbre.

En los pensamientos de negación se observó que a los atletas se les dificultaba aceptar la realidad, enfrentar que no participarían, nuevamente, a nivel de alta competencia: 
"Siempre con la locura de que ahorita me llaman para volver a jugar. Una locura que me duró varios años... En cualquier momento me llaman y me dicen para volver a jugar ...y me llaman para la selección y me voy al extranjero... Y es una locura, es muy difícil cuando te retiras." (Futbolista, 52 años).

"No aceptar que me tenía que retirar... ¿voy a estar lista para Barcelona 92? ¿Tú crees que voy a estar lista para las Olimpiadas?... Creo que en el 2000 ya recién comencé a procesarlo." (Voleibolista, 56 años).

Asimismo, una atleta que consideró el retiro como algo injusto, surgiendo la necesidad de culpar a alguien:

Quise echarle la culpa a alguien, pensé que era un tema de alimentación y como éramos tan pobres no teníamos para comer, entonces mi cartílago era más débil ... ¿Por qué yo?... ¿Por qué me cortaron esa posibilidad? (Voleibolista, 56 años).

En los pensamientos de aceptación los deportistas fueron conscientes de su situación y hacían frente a la nueva etapa que les tocaba vivir:

"Me puse a pensar: de repente tengo otras oportunidades en otra cosa. Como que lo vi de manera optimista... Qué pasa si no salía embarazada y seguía, de repente me iba a aburrir, de repente ya no iba a querer nadar nunca más." (Nadadora, 26 años).

"Me cuestionaba: ¿con cuanto puedo vivir? Yo gano 10000 dólares ya con eso vivo, tengo mis ahorros, tengo mi casa, tranquilo. Y ya me he preparado para afrontar la vida ... 
Entonces eso me dio tranquilidad, tenía un respaldo. Me retiraba, pero todo estaba controlado, tenía mi tiempo libre, se abrían puertas... es un reto y los retos los enfrento, trato de hacerlo de la mejor manera. " (Futbolista, 68 años).

Por último, la incertidumbre aparecía cuando los deportistas no sabían cómo continuar después de la carrera deportiva, qué hacer después:

"Yo sentía que lo único que sabía hacer era jugar fútbol, entonces era el temor de ¿ahora qué voy a hacer? Y si hubiera jugado más la Champions, y si hubiera... ¿Por qué me retire? Hubiera seguido jugando unos años más. ¿Y si regreso?” (Futbolista, 52 años).

"Es una incertidumbre que tú no sabes cómo va a ser tu día de ahora en adelante...Ahora que viene después." (Voleibolista, 50 años).

En base a lo presentado, se observa que a unos deportistas les costó aceptar que había llegado el final de la carrera, teniendo pensamientos que negaban la realidad, para así evitar el dolor que podría causar el reconocer que definitivamente la carrera deportiva había concluido. Asimismo, uno de los participantes consideró que el retiro era un evento injusto, el cual no debían estar enfrentando todavía, esto no les permitió tener un cierre adecuado, lo que generó malestar emocional y dificultó el proceso de adaptación. Otros atletas tuvieron pensamientos de aceptación, enfrentando directamente la situación, esto les permitió sentirse tranquilos durante el proceso de transición. Finalmente, en cuanto a los pensamientos de incertidumbre, se aprecia similitud con lo referido por Romina Plataroti (2008) al hablar acerca de su propia 
experiencia de retiro, describiéndola como un momento de inseguridad e indecisión, de no saber quién era ella fuera del campo deportivo. Igualmente, González y Bedoya (2008), mencionan que al retirarse los deportistas se preguntan cómo hacer para incorporarse en otras áreas y cómo hacer frente a nuevas facetas que no han podido ser del todo desarrolladas a causas del tiempo dedicado al deporte. Frente a ello, se observó que los pensamientos van de la mano con las reacciones emocionales, como, por ejemplo: los pensamientos de incertidumbre generaban ansiedad y miedo en relación al futuro incierto. Cabe mencionar, que solo los pensamientos de aceptación permitían que el deportista se adapte con mayor facilidad a esta nueva etapa.

\section{Impacto del retiro}

Dejar la carrera deportiva tiende a ser una etapa difícil, ya que deben adaptarse a nuevos roles sociales y profesionales. Frente a ello, el cambio en el estilo de vida puede generar un fuerte impacto en el deportista (Gouttebarge et al., 2015), siendo un periodo crítico para muchos de ellos. Se hablará del impacto en el aspecto: Personal, Social, Económico y Familiar.

\section{a. Aspecto Personal}

Para algunos participantes el retiro tuvo un fuerte impacto a nivel personal; siendo visto en la mayor parte de los casos como algo negativo; sin embargo, hubo quienes asumieron el retiro como algo positivo:

“Cuando eres futbolista te hacen todo, te vuelven muy inútil... eres un tarado que no sabe hacer nada, pero bueno, vas aprendiendo... fue duro, prácticamente te forman como un inútil porque todo te hacen y encima te pagan por eso." (Futbolista, 52 años). 
"Me costó mucho con los temas de ansiedad, empecé a comer un montón, me engordé un montón... más de 20 kilos. El hecho también de haberme engordado me deprimió... también me deprimió sentir que no estaba haciendo nada diferente al resto. Sí me costó bastante, de hecho, hasta ahora me cuesta porque... tu vida por 16 años haya sido toda disciplinada y ahora me cuesta bastante no tener una meta... No sabía que estudiar, no sabía qué hacer con mi vida, me tomé un año sabático... Me metí a comunicaciones porque en fin...después entré a Periodismo deportivo, pero ahora he dejado la universidad, he renunciado al trabajo porque necesito un descanso, que pasa, es que yo soy blanco o negro... En decisiones que he tomado en cuanto a mi vida personal he sido totalmente inestable. Me volví un poco loca (se ríe), salía, hacía lo que quería, tomaba un montón sin límites... Dije: ahora es momento de vivir... y bueno, después el trago, el salir y no tener un sentido de vida te deprimen... estaba inestable totalmente porque ya no tenía un horario y tenía mucha más libertad... Me retiré y por 8 años no fui a una piscina a nadar, no podía. Estaba peleada con la natación, sentía que me había quitado un montón de cosas que el resto de gente si normalmente podía vivir.” (Nadadora, 28 años).

“Me volvieron a operar...yo entré con tal desesperación, desanimo... que me abandoné. Cuando salí de la sala de operaciones no reaccionaba. El doctor le dijo a mi amigo: o tú haces algo o tu amiga se muere porque ella no quiere vivir... Recién ahí acepté que uno puede morir por algo o por alguien, y en este caso era el deporte. Yo entiendo que unos deportistas mueran alcohólicos, drogadictos, enfermos... porque cuando te cortan algo que es parte de ti es muy duro de aceptar... El problema era que cuando me iba a dormir, yo seguía jugando vóley, yo seguía viendo a Mambo Park, y años de años duró eso, pero 
como al día siguiente tenía que levantarme y hacer algo, ya lo procesaba... Me volví más agresiva, más contestona, más rebelde hacia la vida porque le estaba echando la culpa porque me quitaron lo que más apreciaba... El proceso de adaptación al retiro me ha durado bastante." (Voleibolista, 56 años).

"No hice un desentreno... ahora que soy entrenador comprendo que hay un proceso de desentreno” (Boxeador, 65 años).

"No hubo impacto a nivel personal porque era consciente que era lo que tocaba. Ya te toca y no puedes echarle la culpa a nadie; sí, ya no puedo correr los 90 minutos y estar en el ritmo intenso." (Futbolista, 72 años).

“Lo que sí es irreversible son las lesiones, como queda tu cuerpo después del desgaste... tanto le diste a la máquina que ya se gastó... Me daban ataques de pánico, me faltaban cosas que hacer. Me despertaba en las noches con una sensación de qué pasa, no podía dormir. Me tuvieron que dar una pastilla que me quedaba dormida 3 días, pero después ya se regularizó... Te digo que fue fuerte porque nunca en mi vida pensé que podía ser una persona depresiva. Hasta me dolía el cuerpo súper fuerte, fui al médico y me dijo que tenía fibromialgia, una enfermedad que es psicosomática...” (Voleibolista, 50 años).

"No sentí un impacto porque el cambio fue cuando comencé a ser estrella... todos los halagos me comenzaron a mortificar. Entonces yo retirado me sentía más tranquilo... ya no estoy en el ojo de todos". 
El estilo de respuesta que tenga el atleta al retirarse, va a depender del enfoque que el deportista le ha dado a su carrera deportiva y el espacio que ésta haya ocupado en su identidad (Alfermann y Stabulova, 2007; Pizarro, 2015). Frente a lo mencionado, los participantes que consideraban a la identidad deportiva como la totalidad de su identidad se vieron fuertemente afectados por el retiro, lo cual generó en ellos una serie de problemas emocionales y físicos, que perjudicó su capacidad para adaptarse a esta etapa. González y Bedoya (2008) afirman que es usual la aparición de una crisis de identidad, debido al grado de identificación con su rol deportivo, de manera que, a mayor identificación, mayor será la crisis. Hallazgos previos mencionaron que los ex deportistas sufren de algún problema de salud mental, en especial síntomas de ansiedad y depresión, prácticas nutricionales inadecuadas; en menor cantidad, baja autoestima, malestar y astenia. Asimismo, Blinde y Stratta (1992) refieren que para algunos el retiro puede tener efectos traumáticos, como caer en el alcoholismo y abuso de sustancias, disminución de confianza en uno mismo e inclusive intento de suicidio (Gouttebarge et al., 2015; citado en Pizarro, 2015). Esto se asemeja a lo mencionado en el presente estudio, como fue comer desmedidamente, provocando una fuerte subida de peso, generado por la falta de ejercicio y niveles elevados de ansiedad; además, esto afectó la autoestima de la participante, provocando un cuadro depresivo. Por otro lado, una de las participantes comenzó a salir a fiestas y a tomar alcohol en exceso, puesto que quería recuperar y disfrutar todo lo que se había perdido mientras entrenaba. Cabe resaltar, que la mayor parte de los participantes mencionaron haber atravesado por cuadros de ansiedad y depresión durante el proceso de transición, lo cual generó, en unos casos, ataques de pánico, insomnio, inestabilidad emocional (mayor agresividad y rebeldía) y fibromialgia. Sin embargo, a diferencia de las investigaciones previas, ninguno de los participantes reportó 
problemas de abuso de sustancias ni intento de suicidio; no obstante, en uno de los casos se reportó falta de deseo de vivir; así como una pérdida del sentido de vida. En cuanto al desgaste físico, éste también produjo un impacto negativo, pues se ha visto que las afectaciones físicas producen un retiro menos saludable. Frente a ello, los participantes no pasaron por un proceso de desentrenamiento, que los preparara a nivel físico para afrontar saludablemente el retiro, a pesar que se ha visto que la disminución planificada y gradual de la carga física durante el periodo activo reduce los efectos biológicos al parar la actividad deportiva (Bestard, 2015; y Cury et al., 2008). Cabe señalar, como se mencionó previamente, que estos participantes, independientemente de la causa de su retiro (forzado o voluntario), se vieron fuertemente afectados, como es el caso de la nadadora que se retiró de manera voluntaria: "Me volví un poco loca ... estaba inestable totalmente”. Por el contrario, los atletas que aceptaban el retiro como un periodo natural del ciclo vital y los que no sentían que perdían su identidad al dejar el deporte, afrontaron el retiro con mayor tranquilidad. Inclusive, en un caso, el retiro fue positivo, ya que tanta atención recibida por los fanáticos y los medios de comunicación era agobiante para él.

\section{b. Aspecto Social}

Unos deportistas refirieron que al tener mayor tiempo libre podían reunirse con sus amigos y crearon nuevos espacios para reencontrarse con sus compañeros del equipo. Por otro lado, hubo quienes perdieron contacto con sus amigos del deporte y reconocimiento social, lo que generó sentimientos de tristeza y afectó la autoestima:

"Empecé a juerguiar, a salir los fines de semana, a hacer todo lo que no había hecho." (Nadadora, 28 años). 
Creo que salía más con mis amigos. Y a pesar de no ver a mis amigos del equipo todos los días como lo solía hacer, igual seguíamos saliendo juntos. Hasta el día de hoy nos juntamos, mi pareja actual es de mi equipo." (Nadadora, 50 años).

"Va pasando el tiempo y aparecen unos jugadores nuevos y tú te sientes como relegado. Es un tema del ego, sientes como que ya no soy tan importante, vas sintiendo de a pocos que ya no eres conocido... Después la gente ya no te reconoce. Uno está acostumbrado... a ir a un restaurante y que te reconozcan ... ya no te pasan la voz, ya no te piden autógrafos." (Futbolista, 52 años).
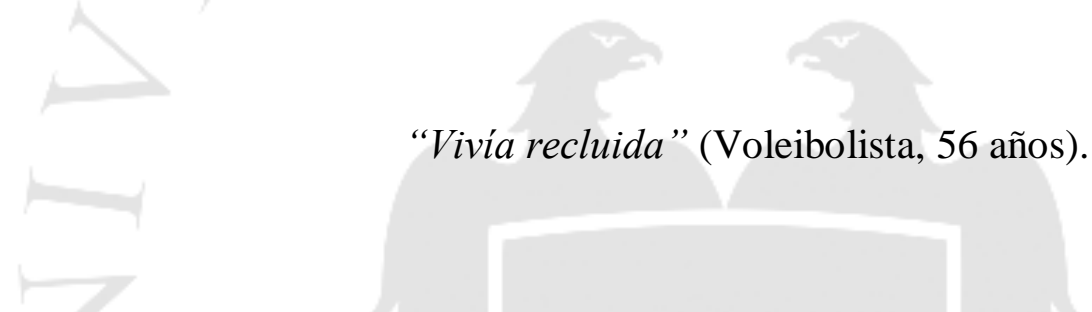

"Todo lo que trae esto es pena, hay amigos que no veo años... Te das cuenta que el actor ya no eres tú, sino le toca a otra persona. "(Futbolista, 72 años).

Se observó que el reconocimiento social influyó fuertemente en el impacto que tuvo el retiro, puesto que la atención del medio cambia completamente una vez que el deportista se retira. Es así que si el atleta ha basado su valor personal entorno a los aplausos, éxitos, elogios, etc. la etapa de retiro se vuelve más difícil, apareciendo un temor a ser olvidados (González y Bedoya, 2008). Por otro lado, para uno de los participantes, el impacto provocó que se aísle, evitando tener contacto con lo relacionado al deporte; de esta manera, impedía la aparición de emociones negativas. No obstante, el retiro, también, puede llegar a tener un impacto positivo, y es que permite a los deportistas retomar su actividad social, pasando mayor tiempo con sus amigos, lo cual fomenta la aparición de emociones positivas. 


\section{c. Aspecto Económico}

Algunos de los deportistas profesionales (recibían un sueldo) se vieron afectados a nivel económico; no obstante, otros supieron manejar adecuadamente sus fondos sin pasar por un momento de desestabilización:

"Fue un golpe drástico, porque el dinero que ganas como futbolista es fuerte, y para que lo vuelvas a ganar es difícil, pero ya más o menos con el tiempo logré estabilizarme, emparejar lo que yo ganaba como futbolista." (Futbolista, 52 años).

“Al contrario, se incrementó, porque mi último contrato que tuve, que fue muy alto, me sirvió para poner mi clínica y para mis campañas políticas que siempre me las pagué yo...

Con ese dinero yo siempre decía: no quiero que mañana más tarde estén haciendo una pollada o estén buscando recursos para darme, para que me pueda atender en un hospital.

Tengo que trabajar duro para mi retiro." (Voleibolista, 56 años).

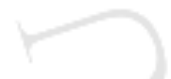

"Ya no ganaba lo que ganaba antes, pero supe administrar buen mi dinero, me organicé y

bueno comencé a ganar en promedio o un poquito más teniendo la tranquilidad de un respaldo." (Futbolista, 68 años).

Para los atletas que percibían un sueldo, el retiro implicó un cambio en los ingresos, ya que para algunos fue difícil dejar de recibir la fuerte suma de dinero a la cual estaban acostumbrados. No obstante, hubo quienes no vieron afectada su situación económica, ya que iniciaron con otro trabajo. Asimismo, los deportistas que refirieron haber ahorrado e invertido correctamente el dinero, no tuvieron un desbalance económico, manteniéndose estable a lo largo del tiempo. Como menciona Prado (2013), la falta de conciencia sobre el 
ahorro ha hecho que muchos deportistas terminen en bancarrota, generando que la etapa de retiro sea una experiencia adversa; surgiendo la preocupación por inculcar una cultura del ahorro, brindándole en muchos países al deportista una capacitación sobre cómo manejar sus finanzas; no obstante, esta es una realidad que no se vive en el Perú. A pesar de ello, ninguno de los participantes pasó por una crisis financiera. Los que tuvieron un desequilibrio económico pudieron estabilizarse al conseguir un nuevo empleo.

\section{d. Aspecto Familiar}

Se observan dos tipos de impacto en las familias, positivo y negativo. El impacto fue positivo, ya que tiempo en familia aumentó; sin embargo, en otros casos el retiro afectó negativamente a algunos miembros de la familia:

Yo creo que tuve un acercamiento mayor a la familia porque cuando yo era boxeador viajaba mucho por las peleas.” (Boxeador, 65 años).

"Fue mejor porque tenía más tiempo de estar con mis hijos, yo nunca me voy a olvidar que mi hijo me decía: ¿Por qué tú no eres como la mamá de fulanito?... ¿Por qué quieres que yo me parezca a ella? Y me dijo: Porque ella siempre está con sus hijos.... (Voleibolista, 50 años)

“Mi papá me presionaba bastante. Para mis papás fue una inversión de tiempo y de plata. El que se levantaba a las 4:30 am para levantarme a mí era mi papá, me llevaba hasta el Regatas, después hasta la molina, después hasta el Regatas otra vez... Y una de las cosas más difíciles que me pasó, fue que mi papá me dejó de hablar por mucho tiempo.... Se molestó horrible y esa fue una de las 
razones por las que yo también dije: no quiero regresar... Impactó mucho porque en casa siempre se hablaba de Fátima y la natación. Para mi papá he sido y soy la favorita porque yo era la campeona. Si impactó... Yo creo que para mí papá también ha sido un impacto emocional porque antes era todo Fátima y hablar de Fátima y dedicarse a Fátima ... y cuando lo dejé seguro se quedó como: ¿y ahora qué hago?... Si él también se lo hubiera tomado de diferente manera, de repente a esa edad, con la rebeldía, hubiera considerado regresar, de repente mi rebeldía bajaba un poco... Mi papá me dejo de hablar, hasta se peleó conmigo. Hasta ahora me lo saca en cara, ya con cariño, pero en varias peleas que he tenido me han sacado en cara...porque también para él debe ser frustrante." (Nadadora, 28

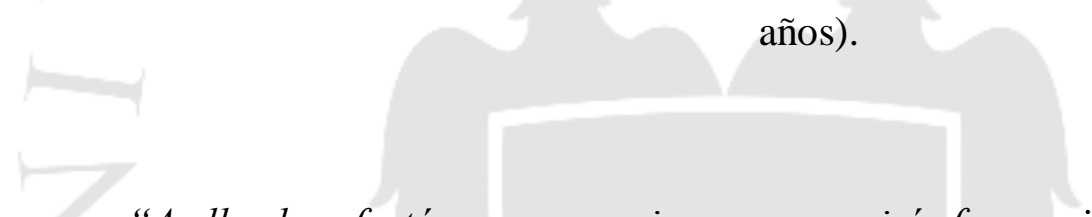

“A ellos les afectó porque gracias a que yo vivía fuera mi mamá conoció Europa, mis hermanos recibían un regalo... Cecilia era cajero automático sin tarjeta. Creo que si les afectó y se molestaron." (Voleibolista, 56 años).

Se observa que el retiro no impacta solo al deportista individualmente, sino que afecta a la familia, ya que el retirarse significaba perder buenas oportunidades, desperdiciar toda inversión de tiempo, esfuerzo y dinero que se había realizado. Esta situación llevó a que los familiares se sintieran defraudados, decepcionados y molestos, incluso llegando a ocasionar conflicto y dañar la relación entre el deportista y su familia. Asimismo, las familias de los deportistas profesionales se vieron afectadas, ya que el deporte al brindarle diversas oportunidades al atleta, también se las brindó a la familia, facilitándoles viajes y una buena posición económica. De manera que la forma cómo es vivenciado el retiro en la familia 
influye en el apoyo que se le dará o no al deportista durante su transición. Puesto que, al ser un impacto negativo la familia no apoya adecuadamente al atleta, generando mayor estrés y angustia en esta etapa. Y, como se verá en la siguiente categoría, "recursos de adaptación", la familia se convierte en un soporte importante para el atleta al momento del retiro, ya que se considera un recurso social que permite una mejor adaptación durante la transición (Lorenzo y Bueno, 2012).

\section{Factores que condicionan la adaptación}

Esta categoría está compuesta por dos subcategorías: Recursos individuales y Sociales.

\section{a. Recursos individuales}

En primer lugar, los participantes contaron con características personales que los ayudaron

a enfrentar esta etapa. Asimismo, las creencias religiosas brindaron mayor tranquilidad durante este periodo:

"Mi carácter, mi personalidad, ser muy disciplinado me ayudó. Además, yo creo que soy medio narcisista, siempre he querido mantenerme bien, también el liderazgo me llevó a siempre querer liderar algo." (Futbolista 52 años).

"La ansiedad la he canalizado en otras cosas, en cuidarme, hacer ejercicio para sentirme bien conmigo misma... Mi carácter, afrontar la situación es que tengo que focalizarme en competir, tengo que focalizarme en ser la mejor. Y así como era la mejor en la universidad, era la mejor juergueando, chupando, fumando... Siempre he sido de extremos." (Nadadora, 28 años). 
"Yo soy una persona resiliente, que cada vez que me he caía, automáticamente, no volteaba la página, la arrancaba y comenzaba desde cero... Soy muy ambiciosa en las cosas que quiero... Mi forma de ser, mi actitud, soy muy renegona y no me gusta ser pobre, creo que no me hubiera quedado llorando de mis trofeos y de mis triunfos, sino seguir superándome... No me quedé a llorar, a mirar TV, a comer y engordar... Soy una persona que no se deja vencer y tengo una actitud que siempre tengo que hacer algo. Sin eso creo que no lo habría logrado... Yo soy perseverante, disciplinada, cuando yo apunto a algo lo logro." (Voleibolista, 56 años).

"Yo en verdad soy bien adaptable, soy relajado.... No soy trágico, no creo que me voy a morir... Siempre me manejo como que Dios proveerá, por algo pasan las cosas... de la nada me salian algunas cositas. Algunos pueden decir suerte, yo digo más fe". (Boxeador,

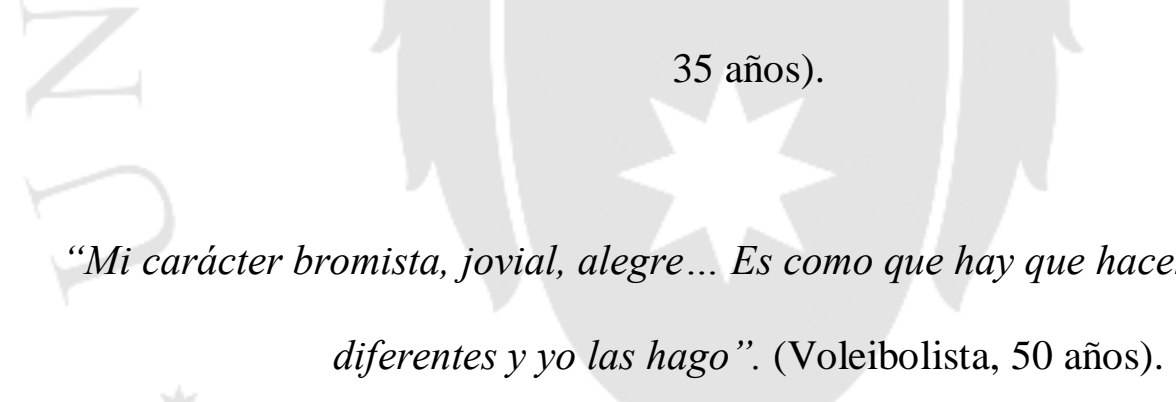

En segundo lugar, se encontró como recurso individual la planificación. Es decir, que algunos deportistas que se encontraron preparados para el retiro, planificando con anticipación lo que realizarían al concluir su carrera deportiva:

"Por más que uno igual se va preparando, una cosa es que te prepares cuando un familiar tuyo está enfermo y sabes que va a morir, pero a la hora que llega la hora, igual duele... 
Yo había pensado en trabajar con menores, yo quería ser entrenador de mayores, siempre mi intención fue ser entrenador de futbol..." (Futbolista, 52 años).

"Creo que me sentía preparada para dejarlo, era algo que había practicado por tanto tiempo que también ya quería pasar a algo nuevo... Sí planifiqué mi retiro y sabía perfectamente lo que quería hacer luego de mi retiro. En ese momento me tocaba estudiar, no podía seguir nadando y estudiando al mismo tiempo..." (Nadadora, 50 años).

"Yo estaba preparado para eso, porque había estudiado, terminé de jugar futbol y dije: bueno soy asistente técnico, voy a hacer una escuela de futbol. Yo ya tenía en mente que cuando me retirara enseñar a los niños. " (Futbolista, 68 años).

"No lo planifiqué. No tenía ni idea de qué iba a hacer." (Nadadora, 28 años).

"No lo planee, eso fue lo más doloroso. Tampoco sabía a qué dedicarme después. Yo creo que ahí las amigas, la familia fueron llenando los espacios..." (Voleibolista, 50 años).

Otro factor influyente es el aspecto económico, ya que tomando las precauciones debidas (ahorrar e invertir correctamente), el atleta se siente más tranquilo en relación a su futuro: "Me enseñaron a guardar pan para mayo y ya había comprado varias casas, las alquilaba y tenía mi sueldo que todavía me llegaba a Alemania e invertí, puse mi clínica ortopédica de rehabilitación." (Voleibolista, 56 años). 
"Tengo mis inversiones, yo no gané demasiado dinero, pero sí lo invertí bien, entonces tenía una estabilidad." (Futbolista, 68).

En cuarto lugar, los deportistas con estudios superiores, pudieron plantearse nuevas metas y objetivos, sintiéndose preparados para enfrentar el retiro. Asimismo, quienes estudiaron después de retirarse, refieren que los estudios llenaban el tiempo y la sensación de vacío que generó el abandono de la actividad deportiva. Además, al estudiar desplegaban competencias que utilizaban en el deporte, favoreciendo su desempeño académico:

"Una de las cosas que reemplazó... el hecho de tratar de ser la mejor y competir, fue estudiar en la universidad. Para mí fue un gran reto lograr las notas que lograba..., y lo valoraba mucha más porque en el colegio me costaba un montón.... Fue muy difícil pero sí se sentía bien...conseguir esos resultados. De repente si no conseguía eso me hubiera frustrado mucho más, hubiera tenido otros problemas." (Nadadora, 28 años).

"Ya habia hecho mi carrera de marketing, mi primera carrera de entrenador de boxeo. Tener estas carreras si me ayudó porque al final no me retiré del todo... Menos mal que habia aprendido este estudio y me iba tranquilo a trabajar" (Boxeador, 65 años).

"Me dediqué de lleno a mis estudios, como te decía, era lo que me tocaba... Yo creo que como empalmé con mi vida universitaria, no me dio tanto tiempo de sentir tristeza ... sino que sabía que lo que tocaba ahora era estudiar." (Nadadora, 50 años). 
Por último, trabajar o realizar actividades de interés personal le permitió al deportista enfocarse en nuevos objetivos, ocupando su tiempo en otras tareas. De esta manera, no tenían tiempo para pensar ni sentirse mal frente al cierre de su etapa deportiva:

"No pude tener cambios emocionales porque cuando terminé tenía estas... actividades, entonces mi cabeza estaba en otra. Yo trabajaba de lunes a viernes y los fines de semana tenía la academia... yo no descansaba, y eso a la par me ayudó a que no pensara y que me entre la depresión... no tenía chance para eso. Además, jugaba y hacía ejercicio... Yo supe sobrellevar el retiro porque de inmediato tuve estas dos actividades... Además, seguir jugando fútbol con gente que no es profesional, de alguna manera me llenaba... Fue fácil adaptarme, porque en realidad yo soy deportista, hay muchos deportistas que cuando dejan el fútbol se engordan, toman y fuman, yo no..." (Futbolista, 52 años).

"Empecé a trabajar como entrenadora... Siempre estuve ligada al tema de la natación... de ahí como profesora de educación física... Ahora yo ya me siento mucho más tranquila... yo creo que ahí fue, en el 2012, cuando comencé a tener un trabajo estable, entonces ya eso de alguna manera me ayudó un poco." (Nadadora, 28 años).

"Fui jardinera en ese interín, mi amigo tenía un vivero y yo me iba con mis muletas... Me dediqué a hacer mil cosas.... No es que yo me quede a llorar, a mirar TV y a engordar." (Voleibolista, 56 años).

“... las tantas horas que se las dedicaba al box ya se las dediqué al jiu-jitsu... Yo creo que ese espacio de retiro lo lleno mi tema de pedagogía, me pude adaptar. Por ese lado no ha 
sido tan trágico mi retirada, no es como que: uy, me retiré y me dedico a tomar y me aíslo y me deprimo. Yo busqué algo que me dé la misma felicidad que me proveía el box...me ayudó bastante para no sentir frustraciones o depresiones ... tenía otro deporte que me complementaba y me gustaba un montón... era como una escapadita. ¿Qué hago con estas emociones? Y pum, las paso al jiu-jitsu... Siempre sientes como un cambio, pero a mí no me agarraban depresiones porque tenía algo a lo que aferrarme." (Boxeador, 35 años).

“... me dedicaba más al trabajo. Me metí a un gimnasio, me puse a pintar, algo que me relajaba. Porque lo que extraña mucho el deportista... Después de toda la adrenalina viene la etapa de calma, esa tranquilidad me lo daba mucho la pintura, lo que es el arte, hacer cosas manuales." (Voleibolista, 50 años)

Según los testimonios previamente planteados, se halló, en primer lugar, que los atletas presentan competencias (liderazgo, perseverancia, resiliencia, etc.) que les permitieron adaptarse al retiro, siendo uno de los factores más influyentes en el proceso de transición. De esta manera, lo mencionado se asemeja a estudios previos, en los que se encontró que las competencias psicosociales, además del género, la edad y tener conciencia de futuro influenciaban en el proceso de adaptación (Wylleman et al., 2004; y Lorenzo y Bueno, 2012). Sin embargo, en la presente investigación, el género y la edad no fueron indicadores determinantes para una mejor adaptación. Por otro lado, uno de los atletas refirió que las creencias religiosas lo ayudaron a sentirse tranquilo, ya que consideraba que un ser superior lo protegía, buscando su bienestar.

En segundo lugar, la planificación fue un elemento que influyó para un retiro saludable, permitiendo una transición más corta y fluida, ya que, como se ha visto en estudios previos, 
ésta brinda una sensación de control sobre la situación y amplía la propia identidad, permitiendo que el atleta se despliegue en otros roles. Es por ello que la falta de preparación es uno de los principales problemas para adaptarse al retiro (Pizarro, 2015; Carlin y Garcés de los Fayos, 2012; y Alfermann y Stabulova, 2007). En los testimonios se observa que la falta de planificación, al no saber qué hacer después de la carrera deportiva, generó incertidumbre, aumentando los niveles de ansiedad. Por el contrario, los que sí planificaron tenían ya establecida una meta para continuar con la siguiente etapa, inmersos en el mundo deportivo o desligándose de él.

En tercer lugar, el tener estabilidad económica proporcionó tranquilidad a los deportistas, ya que, como menciona Prado (2013), el aspecto económico puede generar consecuencias negativas en la vida del deportista retirado si éste se descuida y no maneja bien sus finanzas, pudiendo terminar en la bancarrota.

En cuarto lugar, el aspecto académico es uno de los pilares fundamentales para poder enfrentar de manera exitosa el retiro. Frente a ello, los que estudian una carrera universitaria paralela a la carrera deportiva tienen una mejor transición, adaptándose con mayor facilidad; no obstante, los que se dedican exclusivamente al deporte, experimentan una carga emocional negativa muy fuerte y diversos problemas para adaptarse (Lorenzo y Bueno, 2012; y Pizarro, 2015). Esto guarda similitud con los testimonios, ya que los participantes, al estar respaldados por otra carrera, se sintieron más tranquilos, ya que pudieron desarrollar otras habilidades y abrirse paso en el mundo laboral. Por otro lado, las habilidades y competencias adquiridas en la práctica deportiva, pudieron ser transferidas al ámbito académico, favoreciendo su rendimiento. 
Por último, los participantes realizaron diversas actividades: laborales, deportivas o de interés personal para evitar el malestar emocional, logrando adaptarse al retiro. Se hace evidente que al finalizar la carrera deportiva, el atleta continúa siendo una persona joven, en buen estado físico y mental, encontrándose en la capacidad para realizar otra actividad. Frente a ello, los que tienen una actividad en la cual involucrarse, como lo puede ser un trabajo o aficiones, se adaptan mejor, favoreciendo la salud mental y física. (Pizarro, 2015; Torregrosa, Sánchez y Cruz, 2004; Wylleman et al., 2004; y Duque Ingunza y Dosil, 2017).

\section{b. Recursos sociales}

Las características del entorno, previas y posteriores a la etapa de retiro, son determinantes para la adaptación (Wylleman et al., 2004).

En primer lugar, la familia se convierte en un recurso positivo para la adaptación:

"Si mi papá se lo hubiera tomado de diferente manera, tomando en cuenta mi edad, con la rebeldía, tal vez hubiera considerado su reacción: a ok, no se ha peleado conmigo. Y así de repente mi rebeldía bajaba un poco y regresaba a la natación. Pero mi papá me dejo de hablar, se peleó conmigo, entiendo que para él debe haber sido frustrante." (Nadadora, 28 años).

“Mi mamá...me comenzó a decir: ya regresarás algún día, de repente tu hija sale nadadora, piensa en tu carrera ahora. Me dejo de hablar de natación para ayudarme a salir adelante." (Nadadora, 26 años).

“...Me apoyaban en el sentido de no darle mucha importancia, de no hacerlo que fuera una tragedia... algo normal y que yo me tengo que adaptar.” (Voleibolista, 50 años). 
En segundo lugar, el apoyo de los pares y el cariño de los hinchas son un factor importante que facilita el proceso de adaptación:

"Mi grupo de amigos fue mi apoyo porque empecé a vivir lo que no había vivido cuando hacía deporte. Cuando hacía deporte no tomaba, no salía, no iba a fiestas." (Nadadora, 26 años).

"Con un grupo de amigos, compañeros de la época, que también estábamos en esa situación y nos arreglamos con la peña de los jueves, y todos los jueves practicábamos fútbol y terminábamos con un almuerzo, era bonito, pero también llegó que ya no los podíamos acompañar... Era bonito porque vivía rodeado de gente que me admiraba... Se me hizo fácil porque la gente me conocía, me decían para ir a comer, me saludaban. Tenía la acogida de los hinchas que me la hicieron fácil y este trato con la gente te permite todo." (Futbolista, 72 años).

En tercer lugar, unos participantes consideraron el soporte psicológico necesario para poder afrontar con mayor tranquilidad el retiro:

"No tuve psicólogo, por eso me parece tan interesante lo que estás haciendo... cómo me hubiera gustado yo retirarme y tener algún apoyo, porque no tienes el apoyo de tu familia porque está molesta, adaptarte es muy difícil porque es otro mundo, otra sociedad. Yo no recibí ninguna ayuda y me hubiera encantado. Yo he tenido mucho tiempo psicólogo deportivo, y a mis papás no se les ocurrió en ningún momento meterme a un psicólogo cuando me retiré. Considero que hubiera sido necesario totalmente." (Nadadora, 28 años). 
"No tuve, pero sí considero que hubiera sido necesario, todo hubiera sido mucho más fácil." (Voleibolista, 56 años).

"No, tampoco creo que hubiera sido necesario. Porque es... como que un día se murió tu papá, obvio pues se va a morir, se va a acabar, todo se acaba. Entonces no lo veo tan trágico. Son cosas que te van a pasar en la vida y las tienes que afrontar. En mi caso de repente no me impactó tanto por mi carácter." (Boxeador, 35 años).

"No siento que hubiera sido necesario un apoyo psicológico, creo que mi esposa fue mi psicóloga.” (Boxeador, 65 años).

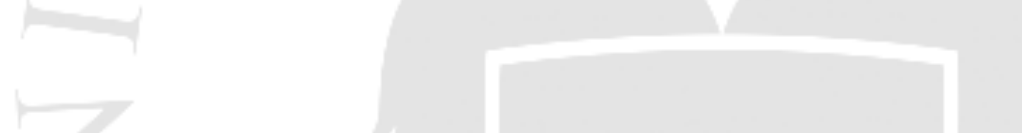

"Nunca tuve apoyo psicológico. Yo creo que es necesario incluso antes de pensar en retirarte, y asi todo se vuelve un proceso." (Voleibolista, 50 años).

“... no creo que necesité por lo mismo que de alguna manera ya tenía en mente qué era lo que me tocaba en ese momento. Tenía que continuar con mi proyecto de vida. ... Pero si considero que la ayuda psicológica es necesario, sobre todo...en que los deportistas no se encuentran preparados para ese momento." (Nadadora, 50 años).

Se observa, que quienes contaron con el apoyo de su familia se sintieron reconfortados, pues ésta brindó un espacio de apoyo incondicional, en el que se les contuvo emocionalmente y alentó para continuar con nuevos proyectos. Por otro lado, quienes no recibieron apoyo familiar, consideraron que éste era necesario para facilitar el proceso de adaptación. La 
información hallada se ve confirmada por Duque-Ingunza y Dosil (2007), al referir que el apoyo de la pareja y otros miembros de la familia funcionan apropiadamente como un recurso para la adaptación.

Asimismo, los amigos permiten a los atletas experimentar emociones positivas y distraerse de pensamientos negativos relacionados al retiro. En un estudio se encontró que los deportistas que se sintieron apoyados por sus amigos al retirarse, se adaptaron con mayor facilidad y favoreció la transición (Duque-Ingunza y Dosil, 2017). Además, el continuar en contacto con los compañeros del deporte, permitía compartir la experiencia, sintiéndose acompañados durante el proceso de transición. Por otro lado, el apoyo y reconocimiento de los hinchas generaba emociones positivas, fomentando una sensación de transcendencia y permitiéndoles aceptar el retiro sin temor a ser olvidados.

Por último, se encuentra una ausencia total de apoyo psicológico durante la etapa de retiro. Frente a ello, los deportistas tienen opiniones polarizadas: por un lado, hay quienes indican que la presencia de un psicólogo es necesaria e indispensable para promover un retiro saludable, brindando estrategias de afrontamiento. Se conoce que el apoyo psicológico debe iniciar antes del retiro; de manera que se convierta en un proceso y no tenga un impacto con una fuerte carga negativa. Asimismo, estudios previos indican que el deportista debe contar con el apoyo de un equipo multidisciplinario (colectivos pedagógicos, instancias médicas y psicológicas del deporte) que brinde ayuda para ponerle fin a la carrera deportiva, buscando que el retiro sea lo menos traumático posible y previniendo que aparezcan secuelas físicas, sociales, profesionales y psicológicas (Bestard, 2015; Vidaurreta y Rojas, 2015; Stambulova, 2010 citado en Carlin y Garcés de los Fayos, 2012). Por otro lado, unos deportistas no necesitaron de apoyo psicológico, ya que bastó con sus propios recursos para adaptarse, 
utilizando a otras personas para hablar y desahogarse. Frente a ello, se observa que compartir los sentimientos durante el retiro favorece la adaptación (Richardson, 2009); hallándose que un espacio de contención emocional y consejería fomenta las emociones positivas durante esta etapa, no necesariamente de la mano de un psicólogo. Cabe resaltar que hubo quien consideró que el retiro no fue una etapa crítica y que el apoyo psicológico no tenía lugar. En base a lo mencionado, se considera que el soporte psicológico es un factor de gran importancia para una adecuada adaptación, ya que brinda herramientas a los deportistas que facilitan el proceso de transición, evitando que el retiro sea experimentado como algo traumático; no obstante, esto no puede ser aplicado en todos los casos, ya que algunos han podido manejar adecuadamente este periodo sin un apoyo psicológico.

\section{Satisfacción Actual}

La última categoría busca conocer el nivel de satisfacción de los participantes con su vida actual. Está compuesta por: Alto nivel de satisfacción y Bajo nivel de satisfacción.

\section{a. Alto nivel de satisfacción}

El alto nivel de satisfacción está relacionado a una sensación de trascendencia, de contribuir a su entorno, ya no con un rol de deportista, sino desempeñándose en otras áreas dentro o fuera del deporte. Asimismo, tener un rumbo en la vida, tener estabilidad y el agradecer todo lo que los rodea; favorece la sensación de satisfacción:

"Me sentí satisfecho, sobre todo con la academia. Ayudar a los niños a alcanzar sus sueños ... te llena ... En el aspecto laboral me siento súper orgulloso." (Futbolista, 52 años). 
"Sí, yo creo que si me siento satisfecha. Llegué a lograr lo que quería... Por esa parte fue satisfacción personal porque pude volver a probarme a mí misma que podía de nuevo. Después con mi trabajo fue igual, de repente no me gusto mi trabajo, pero me di cuenta que con la natación pude lograr otro tipo de trabajo. Con mi hija sigo avanzando porque... tienes que tener la paciencia del mundo, de repente la natación también me ayudó para eso. En relación de pareja y familia también porque... me daba más tiempo para estar con mi familia." (Nadadora, 26 años).

"Ahora me siento un hombre logrado. El boxeo me dio bastantes satisfacciones... Y ahora a través de mis pupilos siento mucha satisfacción con ello....” (Boxeador, 65 años).

"Si siento satisfacción, el hecho que la gente todavía nos recuerde, todavía me inviten a participar a diferentes actividades, que no nos olvidan, siento que dejé una huella...

Siempre me siento admirado y eso me llena. Me deja tranquilo esa satisfacción de decir; he hecho algo." (Futbolista, 68 años).

Lorenzo y Bueno (2012), hallaron que los deportistas de su estudio no sintieron distress, ya que utilizaron estrategias que le permitieron manejar positivamente esta etapa, manteniendo una actitud positiva, sintiéndose satisfechos con su vida actual. Asimismo, en el presente estudio, la mayor parte de los participantes sienten niveles elevados de satisfacción con su vida actual, ya sea por las nuevas actividades que realizan o por los roles que desempeña, recordando con gratitud el pasado, pues el deporte les ha brindado diversas oportunidades laborales, competencias personales, habilidades y reconocimientos hasta la actualidad, lo cual genera una sensación de trascendencia. 


\section{b. Bajo nivel de satisfacción}

Otros mencionaron que el nivel de satisfacción no era el mismo que cuando realizaban deporte, debido a no sentir el mismo disfrute mientras realizaban estas nuevas actividades: "Sí sentí satisfacción, pero nunca va a ser lo mismo, para mí hay gente que si le encanta y le aloca estudiar, para mí no. Lo hago porque lo tengo que hacer.” (Futbolista, 52 años).

"El trabajo no fue el amor de mi vida como lo fue la natación, pero por lo menos sentía que hacía algo adicional." (Nadadora, 28 años).

"No me sentí del todo satisfecho, siempre me faltaba algo..." (Boxeador, 65 años).

Es probable que el nivel de satisfacción con la vida no haya sido bajo en todos los ámbitos; no obstante, en el aspecto laboral o de actividades de interés, sí se evidencia un bajo nivel de satisfacción. Duque-Ingunza y Dosil (2017), refieren que no muchos son los deportistas que indican sentirse muy poco satisfechos con la vida al concluir su carrera deportiva, al igual que en el presente estudio. Asimismo, ninguno de los participantes se sintió nada satisfecho. Frente a ello, se observa, a nivel general, que los deportistas lograron adaptarse satisfactoriamente al retiro; sin embargo, algunos consideraron que el nivel de satisfacción nunca fue el mismo al que sintieron durante la carrera deportiva.

A partir de este estudio se ha podido conocer más a fondo la forma de vivenciar el retiro deportivo y el impacto que genera, tanto positivo como negativo. Asimismo, se observaron los recursos con los que contaron los atletas para sobrellevar esta etapa. 
Cada participante vivencia el retiro de manera única, proporcionándole un significado distinto; que influirá durante el proceso de adaptación. Además, los recursos individuales y sociales con los que contaron los participantes fueron cruciales para poder sobrellevar este proceso de transición, siendo para unos más sencillo que para otros.

A diferencia de otros estudios, en los que las repercusiones y consecuencias del retiro son devastadoras, como caer en el consumo y adicción de sustancias, vivir en la pobreza después de haber gozado de muchos privilegios a nivel económico, e inclusive tener ideas suicidas; en el presente estudio, a pesar de que algunos pasaron por un periodo de crisis bastante difícil, en general los participantes pudieron enfrentar de manera exitosa el proceso de transición. No obstante, en la mayor parte de los casos, se recalcó la importancia del apoyo psicológico como recurso de adaptación, ya que hubiera contribuido a mejorar las estrategias de afrontamiento y a facilitar el proceso de adaptación, generando mayor tranquilidad y alivio, reduciendo las emociones negativas y promoviendo las positivas.

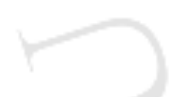

Es importante mencionar que, para llevar a cabo el presente estudio, debió tomarse en cuenta las posibles limitaciones que pudieron haber aparecido al momento de realizar la investigación. En primer lugar, se observó cierta dificultad para acceder a la muestra; así como para alcanzar el número necesario de participantes para llegar al punto de saturación. Finalmente, se debió tener cuidado para establecer una buena alianza con el participante, de manera que éste se sintiera cómodo a lo largo de la entrevista y pudiera brindar respuestas sinceras, sin verse influenciadas por la deseabilidad social. Es así que se logró obtener información clave para el objetivo de la investigación. 


\section{CONCLUSIONES}

- Los deportistas vivencian el retiro de forma particular y única, ya que intervienen diversos factores, tanto personales (identidad deportiva, características de la personalidad, causa del retiro, planificación, estudios paralelos, etc.) como externos (apoyo social, condición económica, etc.), que influyen de manera positiva o negativa en el impacto que tiene el retiro en la vida de los atletas.

- Los deportistas suelen experimentar con mayor frecuencia emociones de valencia negativa, como tristeza, ansiedad, nostalgia, culpa, ira, etc. Sin embargo, en ocasiones, dependiendo de las circunstancias de su retiro o de su personalidad, los deportistas experimentan emociones de valencia positiva al retirarse, como alivio y tranquilidad.

- La duración e intensidad de las emociones de valencia negativas en los participantes varía dependiendo de la efectividad de los recursos de adaptación con los cuales cuentan los deportistas, siendo más determinantes las competencias personales y el tener una ocupación, sea esta laboral o recreativa.

- Los pensamientos de negación, injusticia e incertidumbre lentifican el proceso de adaptación al generar mayor malestar emocional. Por el contrario, los pensamientos de aceptación fomentan la aparición de emociones positivas que facilitan el proceso de transición; sin embargo, esto no significa que las emociones negativas desaparezcan, solamente disminuyen su intensidad.

- La planificación previa al retiro previene la aparición de pensamientos de incertidumbre, reduciendo la sensación subjetiva de ansiedad. 
- Quienes se retiraron de manera voluntaria motivados indirectamente por circunstancias que les generaban malestar, a pesar de experimentar al inicio alivio y tranquilidad; posteriormente se sintieron arrepentidos de la decisión tomada, dificultando el proceso de adaptación.

- Mientras mayor libertad haya al momento de tomar la decisión de retirarse, menor será el malestar emocional, facilitando la adaptación al retiro.

- El contar con diversos recursos de adaptación, a nivel individual y social, para enfrentar el periodo de retiro promueve una adaptación más rápida y fluida al retiro.

- El significado personal que los deportistas le dan al retiro es un factor determinante al momento de la transición, ya que, si el retiro es considerado una pérdida o equivocación, el proceso de adaptación se dificulta; mientras que, si el retiro se vivencia como una etapa de transición, continuidad o satisfacción, se genera un impacto positivo que beneficia la adaptación.

- Una identidad deportiva elevada genera que el retiro sea vivenciado como un duelo, ya que el atleta experimenta una tristeza profunda al no saber quién es él fuera del campo deportivo. Ello constituye el principal factor que dificulta el proceso de adaptación.

- El haber estudiado una carrera profesional, en paralelo a la carrera deportiva; así como, el realizar otra actividad (trabajo, hobbies, etc.) al retirarse del deporte, contribuyen a facilitar el proceso de adaptación, puesto que brindan al deportista una sensación de tranquilidad y control frente al futuro, haciendo evidente que tiene una gama de oportunidades, dentro y fuera del ambiente deportivo. 
- La mayor parte de los deportistas retirados consiguieron trabajos relacionados al deporte que realizaban, inclusive los que estudiaron otra carrera profesional.

- El apoyo psicológico es un recurso vital para favorecer y empoderar al deportista, facilitando el proceso de adaptación, previniendo y disminuyendo el impacto negativo en las vidas de los atletas.

- La familia desempeña un papel importante como soporte para los atletas durante el retiro, ya que brinda un espacio de contención y apoyo emocional, impulsando al deportista a continuar con su proyecto de vida.

- Los deportistas que pasaron por un periodo de inestabilidad económica tuvieron mayor dificultad para adaptarse al retiro; sin embargo, sus recursos (personales y sociales) les permitieron reinsertarse al mundo laboral y estabilizar sus finanzas, de manera que su calidad de vida no se vio afectada.

- A mayor reconocimiento social, mayor dolor emocional y dificultad para adaptarse al retiro. No obstante, el reconocimiento social tiene un impacto importante al retirse, cuando, a pesar del paso del tiempo, el deportista continúa siendo admirado, lo que incrementa el nivel de satisfacción personal.

- El impacto social, en relación al reconocimiento, repercute más en los futbolistas, ya que son ellos quienes reciben mayor atención de los medios de comunicación y beneficios. 


\section{RECOMENDACIONES}

- En primer lugar, se necesita crear conciencia de la importancia de un acompañamiento y soporte a los deportistas retirados, ya que, como se ha visto en el presente estudio, es una etapa difícil y llena de cambios, sobre todo a nivel personal.

De esta manera, se necesita fomentar la participación de un equipo multidisciplinario, conformado por psicólogos, fisioterapeutas, el entrenador y otros especialistas para que puedan preparar al atleta con anticipación para su retiro, de esta forma podrán tener un proceso de transición más armonioso. Asimismo, con la información recolectada se puede apreciar la gran necesidad por formar psicólogos deportivos, que brinden soporte no solo a los deportistas mientras se encuentran en vigencia, sino durante toda su carrera, incluido el retiro.

- Plantear y estructurar un programa que busque prevenir las consecuencias negativas que podría llegar a producir el retiro; de manera que se busque preparar al deportista para la etapa posterior a su carrera deportiva, brindando herramientas y estrategias de afrontamiento.

- Desarrollar un taller en el que se le proporcione a los deportistas conocimientos básicos acerca de finanzas y administración; de manera, que puedan invertir correctamente sus ingresos y no pierdan su estabilidad económica al retiro.

- Por otro lado, se recomienda la creación de grupos de apoyo, en los cuales ex deportistas puedan narrar sus experiencias y contar con el soporte de sus colegas que se encuentran viviendo la misma etapa o que ya la hayan superado. 
- Las Federaciones Deportivas deben fomentar, mientras se desarrolle la carrera deportiva, que se estudie en paralelo otra carrera profesional, relacionada o no al deporte, ya que contar con otra profesión una vez concluida la etapa deportiva, trae mayor seguridad al atleta, permitiendo tener mayores recursos para afrontar el retiro.

- Para futuras investigaciones se recomienda un enfoque cuantitativo que permita evaluar y recolectar datos más exactos acerca de las reacciones emocionales presentadas por los deportistas, así como, para establecer la incidencia de trastornos.

- Para los siguientes estudios se sugiere ampliar la muestra de deportistas para lograr recolectar mayor información acerca del impacto que produce el retiro en las vidas de los atletas.

- Promover investigaciones que traten con mayor profundidad los recursos de adaptación utilizados por los deportistas.

- Crear un fondo económico para los atletas que sufren lesiones o discapacidades producto de la carrera deportiva; de manera, que cuenten con un respaldo que les permita financiar ciertos gastos, en caso no cuenten con los recursos económicos necesarios. 


\section{REFERENCIAS}

Alfermann, D. \& Stambulova, N. (2007). Career transitions and career termination. En G.Tenenbaum y R. C. Eklund (Eds.), Handbook of sport psychology (pp. 712-733). Hoboken, NJ: John Wiley \& Sons, Inc.

Andréu, J. (2002). Las Técnicas de Análisis de Contenido: una revisión actualizada. Recuperado de http://mastor.cl/blog/wp-content/uploads/2018/02/Andreu.-analisisde-contenido.-34-pags-pdf.pdf

Benés, P. (2018). El proceso de retirada deportiva en los deportistas de élite de taekwondo. (Tesis de Maestría). Universidad de Barcelona, Barcelona. Recuperado de http://diposit.ub.edu/dspace/bitstream/2445/125488/1/TFM-DEE_BenesIbanez.pdf

Bestard, C. (2015). El retiro deportivo: vías para su comprensión. EFDeportes.com, 20(204). Recuperado de http://www.efdeportes.com/efd204/el-retiro-deportivo-viaspara-su-comprension.htm

Blanco, M. y Castro, A. (2007). La muestra en la investigación cualitativa. Nure Investigación,

Recuperado

de http://www.sc.ehu.es/plwlumuj/ebalECTS/praktikak/muestreo.pdf

Cabrita, T., Rosado, A., De la Vega, R. y Serpa, S. (2014). Relaciones entre identidad atlética y personalidad en el deporte de competición. Revista de Psicología del Deporte, 23(2), 247-253. Recuperado de http://www.rpd-online.com/article/view/v23-n2maia-cabrita-boleto-etal/pdf_es 
Carlin, M. y Garcés de los Fayos, E. (2012). Transición de carrera deportiva a un nuevo contexto vital: perspectivas actuales. Cuadernos de Psicología del Deporte, 12(1), 103-110. Recuperado de http://scielo.isciii.es/scielo.php?script=sci_arttext\&pid=S1578-

84232012000100009

Cauas, D. (2015). Definición de las variables, enfoque y tipo de investigación. Bogotá: biblioteca electrónica de la universidad Nacional de Colombia. Recuperado de https://s3.amazonaws.com/academia.edu.documents/36805674/1Variables.pdf?AWSAccessKeyId=AKIAIWOWYYGZ2Y53UL3A\&Expires=1507 576591\&Signature=CWoqehzO4BNYfkQKUk7CVQUMf7I\%3D\&responsecontent-disposition=inline\%3B\%20filename\%3Dvariables_de_Daniel_Cauas.pdf

Cócola, F. (2010). Estrategias de afrontamiento en jugadores de hockey sobre patines (Tesis de licenciatura, Universidad del Aconcagua, Argentina). Recuperado de http://bibliotecadigital.uda.edu.ar/objetos_digitales/34/tesis-980-estrategias.pdf

Córdova, A. (2006). Rol Profesional del Psicólogo del Deporte. EFDeporte.com, 11(96). Recuperado de http://www.efdeportes.com/efd96/psd.htm

Cury, M., Ferreira, M. R. y Leite de Barros, T. (2008). Causas e Conseqüências físicas e emocionais do término de carreira esportiva. Revista Brasileira de Medicina do Esporte, 14(6), 504-508. Recuperado de http://www.scielo.br/pdf/rbme/v14n6/a06v14n6.pdf

Denzin, N., \& Lincoln, Y. (2005). The Sage handbook of qualitative research. Sage Publication Ltd. 
Díaz, L., Tottuco, U., Martínez, M., y Varela, M. (2013). La entrevista, recurso flexible y dinámico. Investigación en educación médica, 2(7), 162-167. Recuperado de https://ac.els-cdn.com/S2007505713727066/1-s2.0-S2007505713727066main.pdf?_tid=7295a7aa-eab1-4849-9e9361ad31d407e2\&acdnat=1544550443_addbb87d8bf1113a10b17dfadc9a14ee

Duque-Ingunza, A., y Dosil, J. (2017). Variables que influyen en la transición deportiva: un estudio con futbolistas en activo y exfutbolistas de la primera división de la LFP. Cuadernos de Psicología del Deporte. 17(3), 13-24. Recuperado de http://scielo.isciii.es/pdf/cpd/v17n3/art01.pdf

García-Naveira, A. (2010). El Psicólogo del Deporte en el alto rendimiento: Aportaciones y retos futuros. Papeles del Psicólogo, 31(3), 259-268. Recuperado de http://www.redalyc.org/pdf/778/77815136005.pdf

Giannone, Z. (2016). Life After Sport: The Relationship between athletic identity and mental health outcomes after sport retirement. (Tesis de Maestría). The University of British Columbia, Vancouver. Recuperado de file:///C:/Users/HP/Downloads/ubc_2016_may_giannone_zarina.pdf

Gimeno, F., Buceta, J. y Pérez Llantada, M. (2007). Influencia de las variables psicológicas en el deporte de competición: evaluación mediante el cuestionario Características psicológicas relacionadas con el rendimiento deportivo. Psicothema, 19(4), 667-672. Recuperado de http://www.redalyc.org/html/727/72719420/

Giraldo, J. (2017). ¿Qué fue de Hugo "Cholo" Sotil? Sport. Recuperado de https://www.sport.es/es/noticias/barca/que-fue-hugo-cholo-sotil-5795374 
González, M. y Bedoya, J. (2008). Después del deporte ¿Qué? Análisis psicológico de la retirada deportiva. Revista de Psicología del Deporte, 17(1), 61-69. Recuperado de http://www.redalyc.org/html/2351/235119246004/

Gouttebarge, V., Frings-Dresen, M., \& Sluiter, J. (2015). Mental and psychosocial health among current and former professional footballers. Occupational Medicine, 65(3), 190-196. Recuperado de https://academic.oup.com/occmed/article/65/3/190/1479375

Guba, E. (1989). Criterios de credibilidad en la investigación naturalista. Madrid: Akal.

Greenleaf, C., Gould, D. \& Dieffenbach, K. (2001). Factors influencing Olympic performance: interviews with Atlanta and Nagano US Olympians. Journal of applied sport psychology, 13(2), 154-184. Recuperado de http://citeseerx.ist.psu.edu/viewdoc/download?doi=10.1.1.461.2209\&rep=rep1\&typ e=pdf

Hernández, N. y Carballo, C. (2002). Acerca del concepto de deporte: alcance de su(s) significado(s). Memoria Académica, 6, 87-102. Recuperado de http://www.efyc.fahce.unlp.edu.ar/article/view/EFyCv06a08

Hernández, S. R., Fernández, C. C., y Baptista, L. P. (2014). Metodología de la investigación (6 $6^{\mathrm{a}}$ ed.). México D.F.: McGraw-Hill Education. Recuperado de http://www.memoria.fahce.unlp.edu.ar/art_revistas/pr.87/pr.87.pdf

Instituto Nacional del Deporte (12 de diciembre de 2018). Funciones del IPD. Recuperado de http://www.ipd.gob.pe/institucional/funciones-del-ipd 
Jofré, I. (2014). Desarrollo de la Actividad Física y Deportiva, Fomento Público y Responsabilidad Social Empresarial (Tesis de Licenciatura, Universidad de Chile, Chile). $\quad$ Recuperada de http://repositorio.uchile.cl/bitstream/handle/2250/115608/dejofre_i.pdf?sequence $=1$

Lorenzo, M., y Bueno, M. (2012). Recursos disponibles para la inserción sociolaboral tras la retirada deportiva de futbolistas. Revista de Psicología del deporte, 22(1), 189194. Recuperado de file:///C:/Users/HP/Downloads/1039-3031-1-PB.pdf

Martínez, M. (2013). Ciencia y arte en la metodología cualitativa (2 $2^{\mathrm{a}}$ ed.). México: Trillas.

Messner, M.A. (1992). Power at Play. Boston, MA: Beacon.

Nieri, D. (2007). La historia de la psicología del deporte en el Perú. Revista de Iberoamericana de psicología del ejercicio y el deporte, 1(2), 121-130. Recuperado de

http://www.dantenieri.pe/images/upload/paginaweb/archivo/23/Historia\%20PD\%2 0Peru\%20RIPED\%20(2007).pdf

Palomino, J., Peña, J., Zevallos, G., y Orizano, L. (2017). Metodología de la investigación: guía para elaborar un proyecto en salud y educación ( $1^{\mathrm{a}} \mathrm{ed}$.). Lima: Edit. San Marcos

Pallarés, S., Torregrosa, M., Azócar, F., Selva, C. y Ramis, Y. (2011). Modelos de trayectoria deportiva en waterpolo y su implicación en la transición hacia una carrera profesional alternativa. Revista Cultura Ciencia y Deporte, 6, 81-156. Recuperado de http://ccd.ucam.edu/index.php/revista/article/view/36/33 
Prado, E. (2013). El retiro deportivo: la carrera del atleta hacia el retiro. CONDUSEF. Recuperado de https://www.condusef.gob.mx/Revista/PDF-s/2013/164/deportes.pdf

Pizarro, M. (2015). Transiciones durante la carrera deportiva: desde el inicio hasta la retirada del deporte de élite. Universidad Autónoma de Barcelona. Recuperado de http://repositorio.uchile.cl/bitstream/handle/2250/135906/Transiciones\%20durante $\% 201$ \% $\% 20$ carrera $\% 20$ deportiva.pdf?sequence $=1$

Plataroti, R. (2008). ¿Ahora quién soy? Retiro y crisis de identidad. Boletín Electrónico de Investigación de la Asociación Oaxaqueña de Psicología, 4(1), 131-135. Recuperado de https://www.psicodeportes.com/ahora-quien-soy-retiro-y-crisis-deidentidad/

Riera Ferran, A. (2003). Análisis comparado del uso del deporte en la publicidad televisiva en España (Tesis doctoral, Universidad de Lérida, España). Recuperada de http://www.tesisenred.net/handle/10803/8063

Richardson, C. (2009). Highly identified females athletes' retirement from collegiate sport (Tesis de maestría, San Jose State University, Estados Unidos de América). Recuperada de https://scholarworks.sjsu.edu/cgi/viewcontent.cgi?referer=https://scholar.google.co m.pe $/ \&$ httpsredir $=1 \&$ article $=4645 \&$ context=etd_theses

Roffé, M. (2000). Retiro del futbolista: el drama del día después. EFDeportes.com, 5(27). Recuperado de http://www.efdeportes.com/efd27a/retiro.htm 
Ruiz, R., y Lorenzo, O. (2008). Características psicológicas en los jugadores de pádel de alto rendimiento. Revista de Iberoamericana de Psicología del Ejercicio y del Deporte, 3(2), 183-200. Recuperado de http://www.redalyc.org/pdf/3111/311126260003.pdf

Torregrosa, M., Sanchez, X., y Cruz, J. (2004). El papel del psicólogo del deporte en el asesoramiento académico-vocacional del deportista de élite. Revista de Psicología del Deporte, 13(2), 215-228. Recuperado de http://ddd.uab.cat/pub/revpsidep/19885636v13n2/19885636v13n2p215.pdf

Tornabene, I. (s. f.). El retiro del deportista: cuando los sueños y desafíos parecen terminarse. Comité Olímpico Español. Recuperado de http://www.coe.es/oad/gesOAD.nsf/0/96FC57B4A17A0954C12576EF005480DA/ \$File/el\%20retiro\%20del\%20deportista.pdf

Verd, J., y Lozares, C. (2016). Introducción a la investigación cualitativa. Fases, métodos y técnicas. Madrid: Editorial Síntesis.

Vidaurreta, L., y Rojas, L. (2015). Desentrenamiento deportivo en Cuba: en busca de un retiro deportivo psicológicamente saludable. Revista Cubana de Medicina Deportiva, 10(1). Recuperado de https://docplayer.es/25876694-Desentrenamiento-deportivoen-cuba-en-busca-de-un-retiro-deportivo-psicologicamente-saludable.html

Vicente-Rodríguez, G., Benito, P., Casajús, J., Ara, I., Aznar, A., Castillo, M., Dorado, C., González-Agüero, A., González-Gallego, J., González-Gross, M., Gracia-Marco, L., Gutiérrez, Á., Gusi, N., Jiménez-Pavón, D., Lucía, A., Márquez, S., Moreno, L., Ortega, F., de Paz, J., Ruiz, J., Serrano, J., Tur, J., Valtueña, J. (2016). Actividad física, ejercicio y deporte en la lucha contra la obesidad infantil y juvenil. Nutrición 
Hospitalaria, $\quad 33(9), \quad$ 1-21. $\quad$ Recuperado de https://www.redalyc.org/pdf/3092/309249471001.pdf

Williams, J. (1991). Psicología aplicada al deporte. Biblioteca Nueva.

Wylleman, P., Alfermann, D., \& Lavallee, D. (2004). Career transitions in sport: European perspectives. Psichology of Sport and Exercise, 5(1), 7-20. Recuperado de https://dspace.stir.ac.uk/bitstream/1893/7648/1/PSE1_2004.pdf

Wylleman, P. \& Lavallee, D. (2003). A developmental perspective on transitions faced by athletes. En M. Weiss (Ed.), Developmental sport and exercise psychology: A lifespan perspective (pp. 503-524). Morgantwon, WV: Fitness Information Techonology. 


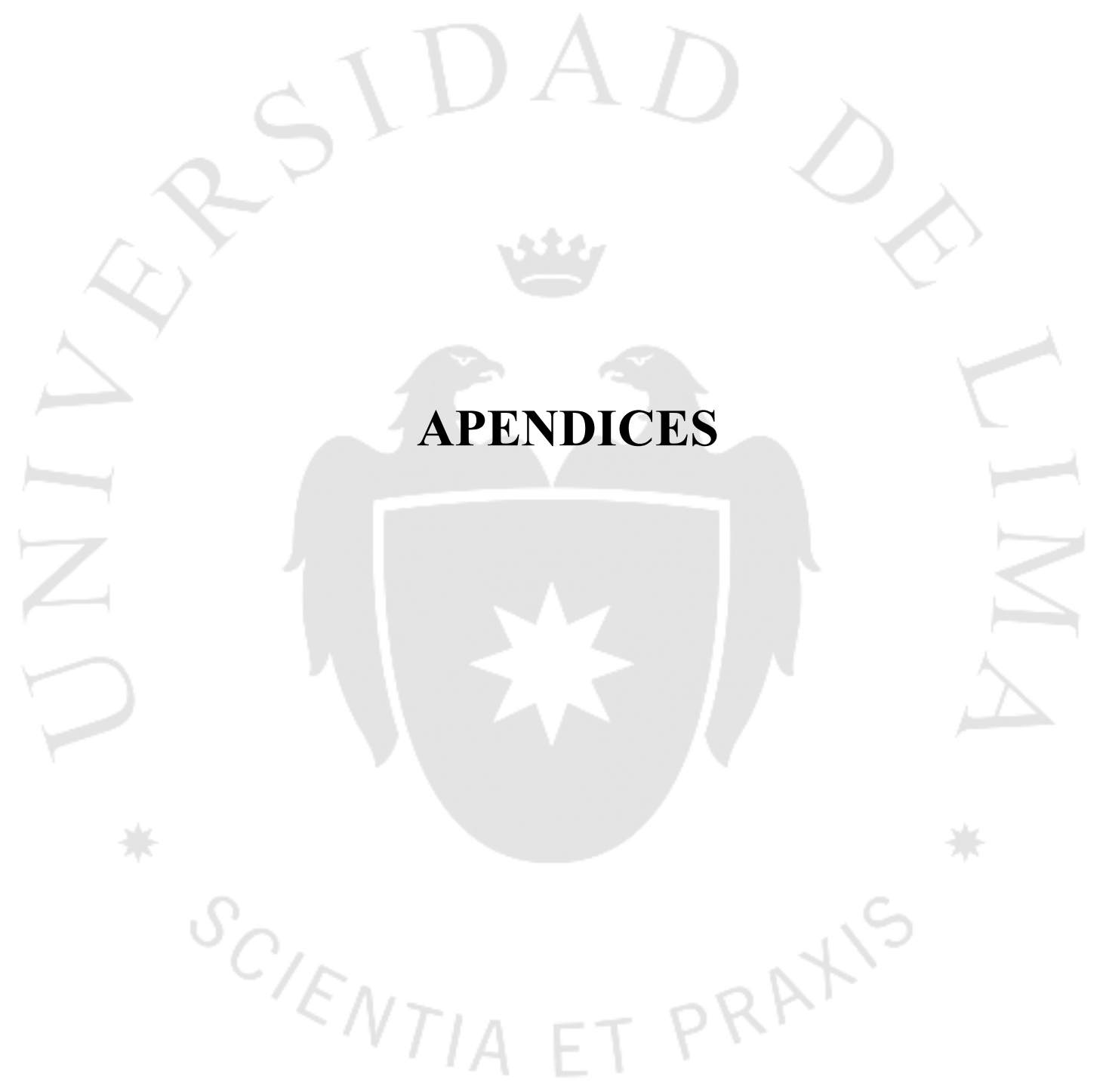




\section{APENDICE 1: GUÍA DE PREGUNTAS}

1. Podría hacer un breve resumen acerca de su carrera deportiva.

2. ¿Qué significaba para usted el deporte que realizaba? ¿Sentía que era parte de su identidad?

3. ¿Qué emociones generaba en usted cuando lo practicaba?

4. ¿Qué acciones tuvo que hacer o dejar de hacer para poder desarrollar su carrera deportiva?

5. Si no hubiera sido deportista, ¿qué hubiera realizado?

6. ¿Cuál fue la causa de su retiro?

7. ¿Cómo vivió esta etapa de retiro?

8. ¿El retiro lo describiría como una pérdida (duelo) ¿Por qué?

9. ¿Qué hizo para afrontar esta situación de retiro?

10. ¿Qué emociones sintió al tomar la decisión de retiro?

11. Una vez culminada la etapa deportiva, ¿sintió cambios emocionales después del retiro?

12. ¿Cuánto tiempo sintió estas emociones? (latencia)

13. ¿Las emociones que sintió durante el retiro fueron intensas? En una escala del 1 al 10, ¿que numero diría?

14. ¿Qué significó para usted la decisión del retiro?

15. ¿Qué pensamientos pasaban por su mente durante ese momento?

16. ¿Qué significa para usted ser un deportista retirado? ¿Se considera aún deportista?

17. ¿Usted planificó con anticipación su retiro? ¿Sabía a qué dedicarse después de retirarse? 
18. ¿Qué hizo para adaptarse al retiro? ¿Fue fácil o difícil?

19. ¿Qué característica personal le ayudó?

20. ¿Tuvo el apoyo de su familia? ¿Le ayudó a afrontar el retiro? ¿Cómo?

21. ¿Tenía algún tipo de estudio? ¿Le ayudó a afrontar el retiro? ¿Cómo?

22. ¿Tenía algún trabajo (paralelo)? ¿Le ayudó a afrontar el retiro? ¿Cómo?

23. ¿Tuvo apoyo psicológico durante el retiro? De no ser así, ¿Considera que hubiese sido necesario el apoyo psicológico?

24. ¿Hubo algún otro grupo social que lo ayudó? (religión, grupo de amigos, etc.)

25. ¿A qué se dedicó luego de su retiro deportivo?

26. ¿Se sintió satisfecho con lo que hacía?

27. ¿En la actualidad sigue dedicándose a lo mismo o ha habido algún cambio?

28. ¿De qué manera impactó el retiro en su situación económica?

29. ¿De qué manera impactó el retiro en su situación familiar?

30. ¿El impacto del retiro tuvo repercusiones en su vida en el aspecto personal? ¿De qué manera?

31. ¿El impacto del retiro tuvo repercusiones en su vida en el aspecto laboral? ¿De qué manera?

32. ¿El impacto del retiro tuvo repercusiones en su vida en el aspecto social? ¿De qué manera?

33. A nivel general, después del retiro ¿ha sentido satisfacción personal en estos aspectos de su vida? 


\section{APENDICE 2: CONSENTIMIENTO INFORMADO}

\section{Anexo P. Consentimiento informado para investigación}

El propósito de esta ficha de consentimiento es proveer al participante en esta investigación una clara explicación de la naturaleza de la misma, así como de su rol en ella como participante.

La presente investigación es conducida por Paola Mendoza Llontop, de la Universidad de Lima. La meta de este estudio es conocer la perspectiva que tienen del retiro los deportistas de alto rendimiento que residen en Lima.

Si usted accede a participar en este estudio, se le pedirá responder preguntas en una entrevista (o completar una encuesta, tests o lo que fuera según sea el caso). Esto tomará aproximadamente 45 minutos de su tiempo. Lo que conversemos durante estas sesiones se grabará, de modo que el investigador pueda transcribir después las ideas que usted haya expresado.

La participación en este estudio es estrictamente voluntaria. La información que se recoja será confidencial y no se usará para ningún otro propósito fuera de los de esta investigación. Sus respuestas al cuestionario y a la entrevista serán codificadas usando un número de identificación y por lo tanto, serán anónimas. Una vez trascritas las entrevistas, las grabaciones o videos se destruirán.

Si tiene alguna duda sobre este proyecto, puede hacer preguntas en cualquier momento durante su participación en él. Igualmente, puede retirarse del mismo en cualquier momento sin que eso lo perjudique en ninguna forma. Si alguna de las preguntas durante la entrevista le parecen incómodas, tiene usted el derecho de hacérselo saber al investigador o de no responderlas.

Desde ya le agradecemos su participación.

Acepto participar voluntariamente en esta investigación, conducida por Paola Mendoza Llontop. He sido informado(a) de que la meta de este estudio es conocer la perspectiva que tienen del retiro los deportistas de alto rendimiento que residen en Lima.

Me han indicado también que tendré que responder cuestionarios, tests y preguntas en una entrevista, lo cual tomará aproximadamente $\underline{45}$ minutos.

Reconozco que la información que yo provea en el curso de esta investigación es estrictamente confidencial y no será usada para ningún otro propósito fuera de los de este estudio sin mi consentimiento. He sido informado de que puedo hacer preguntas sobre el proyecto en cualquier momento y que puedo retirarme del mismo cuando así lo decida, sin que esto acarree perjuicio alguno para mi persona. De tener preguntas sobre mi participación en este estudio, puedo contactar a Paola Mendoza Llontop al teléfono $\underline{980706442}$. 
Entiendo que una copia de esta ficha de consentimiento me será entregada, y que puedo pedir información sobre los resultados de este estudio cuando éste haya concluido. Para esto, puedo contactar a Paola Mendoza Llontop al teléfono anteriormente mencionado.

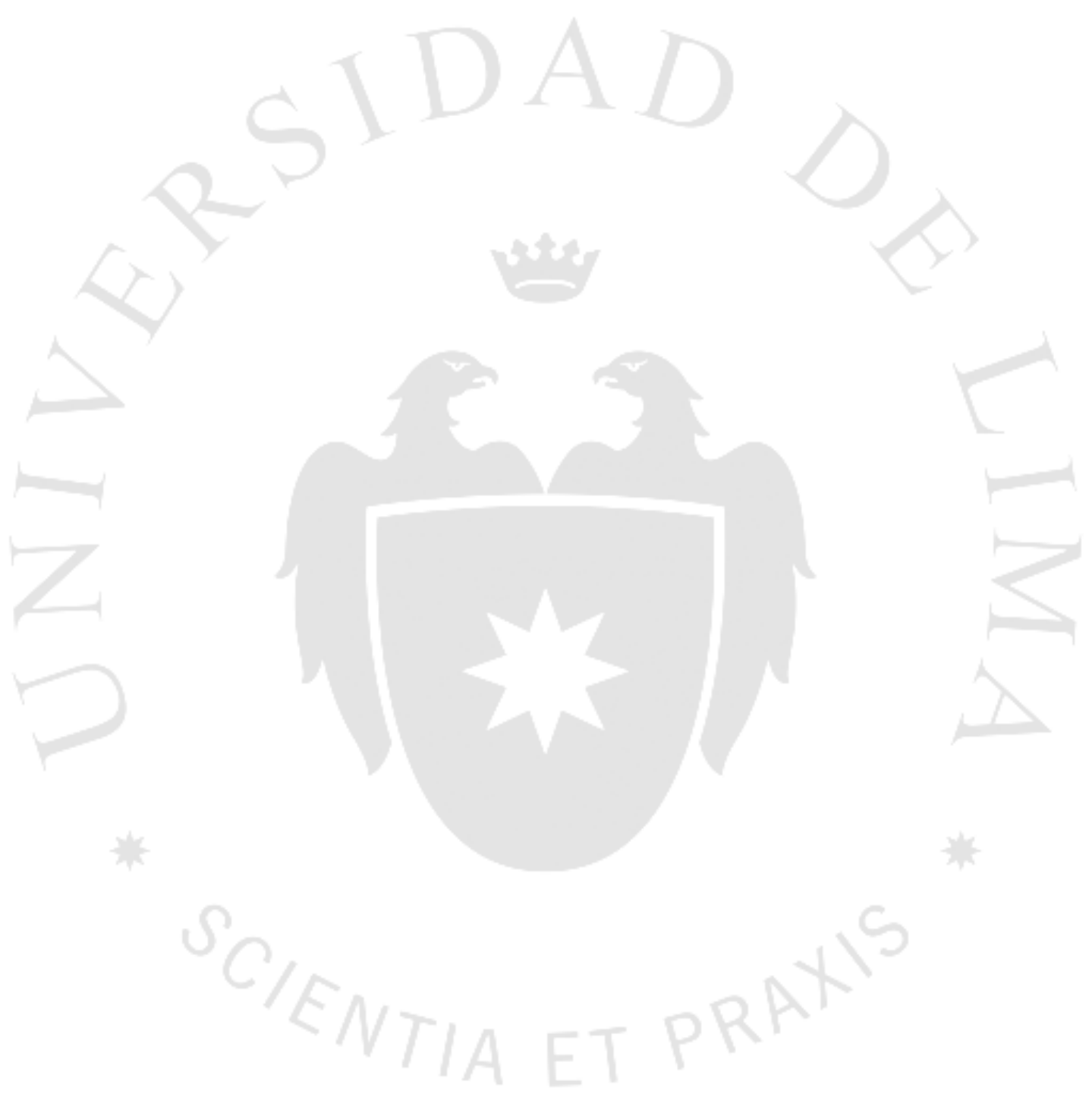




\section{APENDICE 3: CUESTIONARIO DE VALIDACIÓN POR OPINIÓN DE EXPERTOS}

Señor (a) Especialista,

Se le solicita colaborar en el proceso de validación de la guía de preguntas de la investigación "El retiro desde la perspectiva del deportista de alta competencia".

La presente guía de preguntas busca describir la experiencia personal del deportista de alta competencia durante el periodo de retiro.

A continuación, se resumen los principales aspectos que se tendrán en cuenta para determinar en el proceso de validación del instrumento.

\begin{tabular}{|c|c|}
\hline $\begin{array}{l}\text { Objetivos de } \\
\text { la validación }\end{array}$ & $\begin{array}{l}\text {-Evaluar la redacción de las preguntas. } \\
\text {-Evaluar el contenido de las preguntas. } \\
\text {-Brindar observaciones de mejora, de acuerdo a su experiencia dentro del } \\
\text { ámbito de los deportistas de alta competencia. }\end{array}$ \\
\hline Expertos & $\begin{array}{l}\text {-Dos especialistas vinculados al ámbito deportivo de alta competencia. } \\
\text {-Dos psicólogos. }\end{array}$ \\
\hline $\begin{array}{ll}\text { Modo de } \\
\text { validación }\end{array}$ & $\begin{array}{l}\text { Cuestionario de Validación por Juicio de Expertos. } \\
\text { Método individual: Cada experto responde al cuestionario y proporciona sus } \\
\text { valoraciones de forma individualizada. }\end{array}$ \\
\hline
\end{tabular}

La guía de preguntas permitirá que se pueda realizar la entrevista semi-estructurada a profundidad. Se le presentarán 31 preguntas agrupadas de acuerdo a las áreas a explorar: carrera deportiva, experiencia personal del retiro, emociones asociadas al retiro, 
pensamientos asociados al retiro, factores personales de adaptación, factores externos de adaptación y repercusiones del retiro. Estas deberán ser calificadas de acuerdo a los siguientes criterios:

\begin{tabular}{|c|c|c|c|c|}
\hline $\begin{array}{c}\text { 1: Pregunta } \\
\text { muy poco }\end{array}$ & $\begin{array}{c}\text { 2: Pregunta } \\
\text { poco aceptable }\end{array}$ & $\begin{array}{c}\text { 3: Pregunta } \\
\text { regularmente } \\
\text { aceptable }\end{array}$ & $\begin{array}{c}\text { 4: Pregunta } \\
\text { aceptable }\end{array}$ & $\begin{array}{c}\text { 5: Pregunta } \\
\text { muy aceptable }\end{array}$ \\
\hline
\end{tabular}

En el caso de considerar que alguna pregunta es poco o muy poco aceptable para describir la experiencia personal del deportista de alta competencia durante el periodo de retiro, se le invita a indicar la razón o su duda en la casilla de "Observaciones".

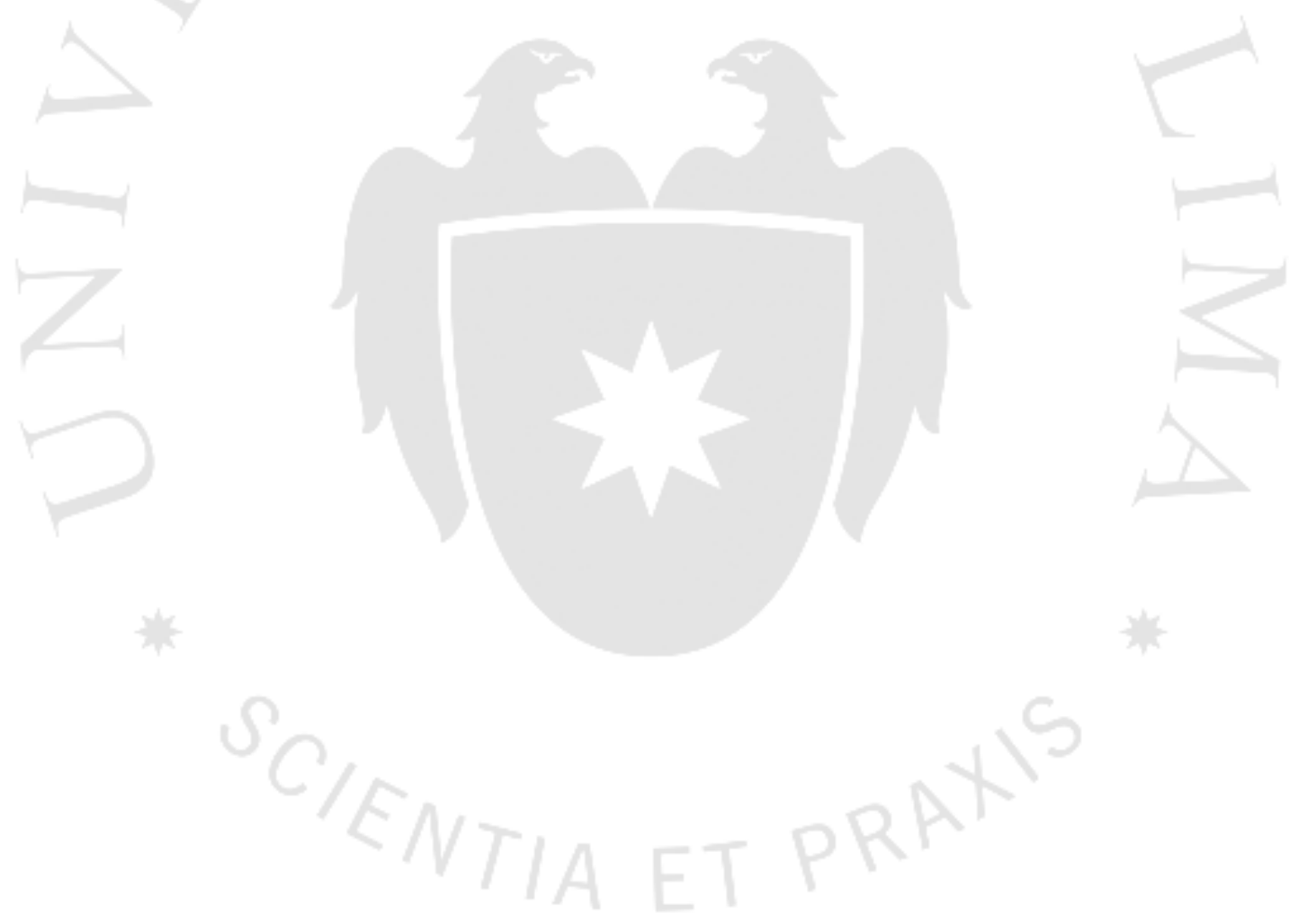




\section{CUESTIONARIO DE VALIDACIÓN POR OPINIÓN DE EXPERTOS}

Nombre:

\section{Especialista en:}

Califique las siguientes preguntas:

\begin{tabular}{|c|c|c|c|c|}
\hline $\begin{array}{l}\text { 1: Pregunta } \\
\text { muy poco }\end{array}$ & $\begin{array}{c}\text { 2: Pregunta } \\
\text { poco }\end{array}$ & $\begin{array}{l}\text { 3: Pregunta } \\
\text { regularmente }\end{array}$ & $\begin{array}{l}\text { 4: Pregunta } \\
\text { aceptable }\end{array}$ & $\begin{array}{c}\text { 5: } \text { Pregunta } \\
\text { muy }\end{array}$ \\
\hline aceptable & aceptable & aceptable & & aceptable \\
\hline
\end{tabular}

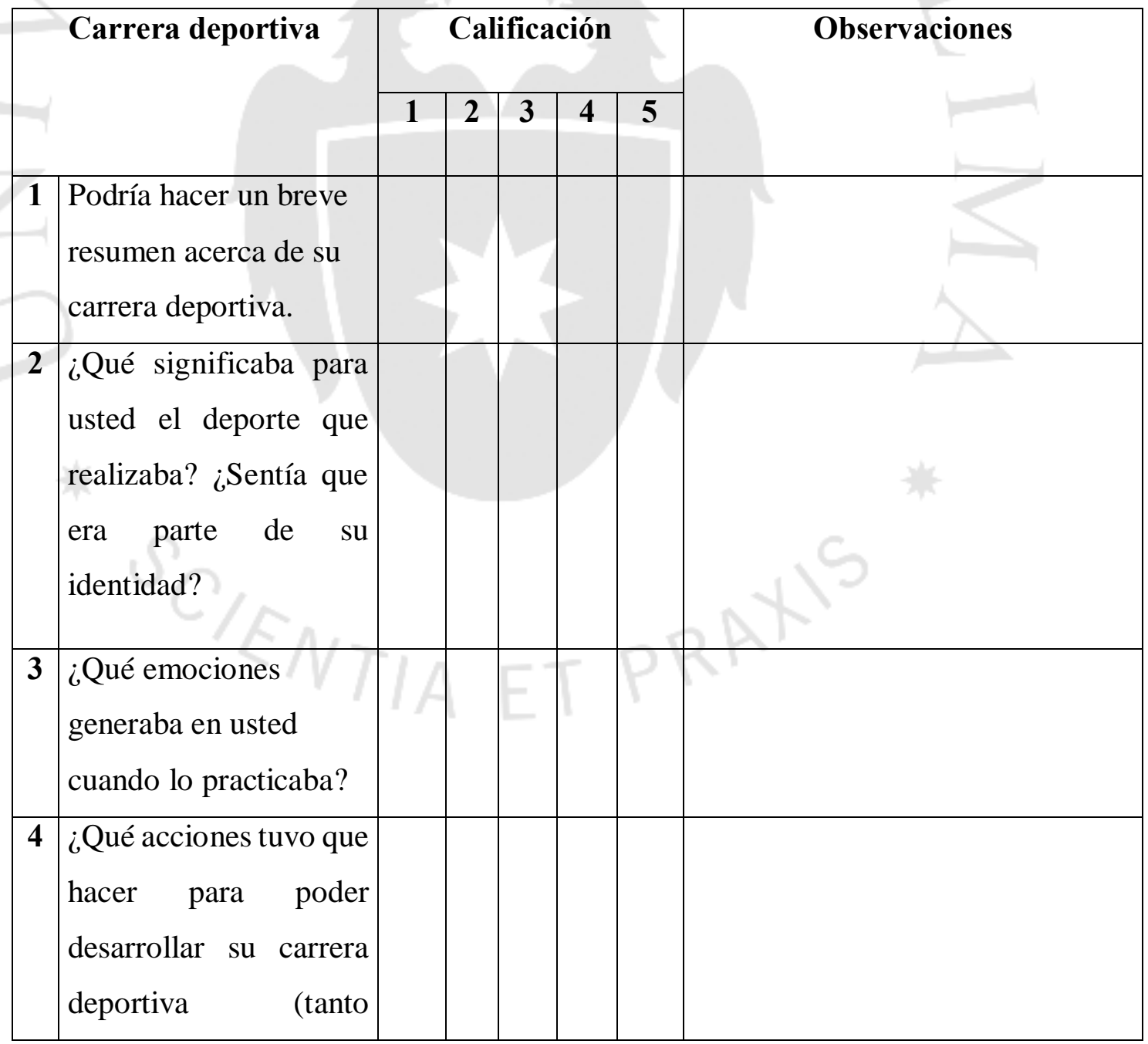




\begin{tabular}{|c|c|c|c|c|c|c|c|}
\hline & \begin{tabular}{|ll} 
positivas & como \\
negativas)? &
\end{tabular} & & & & & & \\
\hline & xperiencia personal del & & Cal & fic: & iión & & Observaciones \\
\hline & retro & 1 & 2 & 3 & 4 & 5 & \\
\hline 1 & $\begin{array}{l}\text { ¿Cuál fue la causa de } \\
\text { su retiro? (motivo) }\end{array}$ & & & 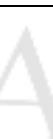 & & & \\
\hline 2 & $\begin{array}{l}\text { ¿Cómo describe esta } \\
\text { etapa? }\end{array}$ & & & 8 & & & \\
\hline 3 & $\begin{array}{l}\text { ¿La describiría como } \\
\text { una etapa de duelo? } \\
\text { ¿Por qué? }\end{array}$ & & & & & & \\
\hline 4 & $\begin{array}{l}\text { ¿Qué hizo para } \\
\text { afrontar esta situación? }\end{array}$ & & & & & & \\
\hline
\end{tabular}

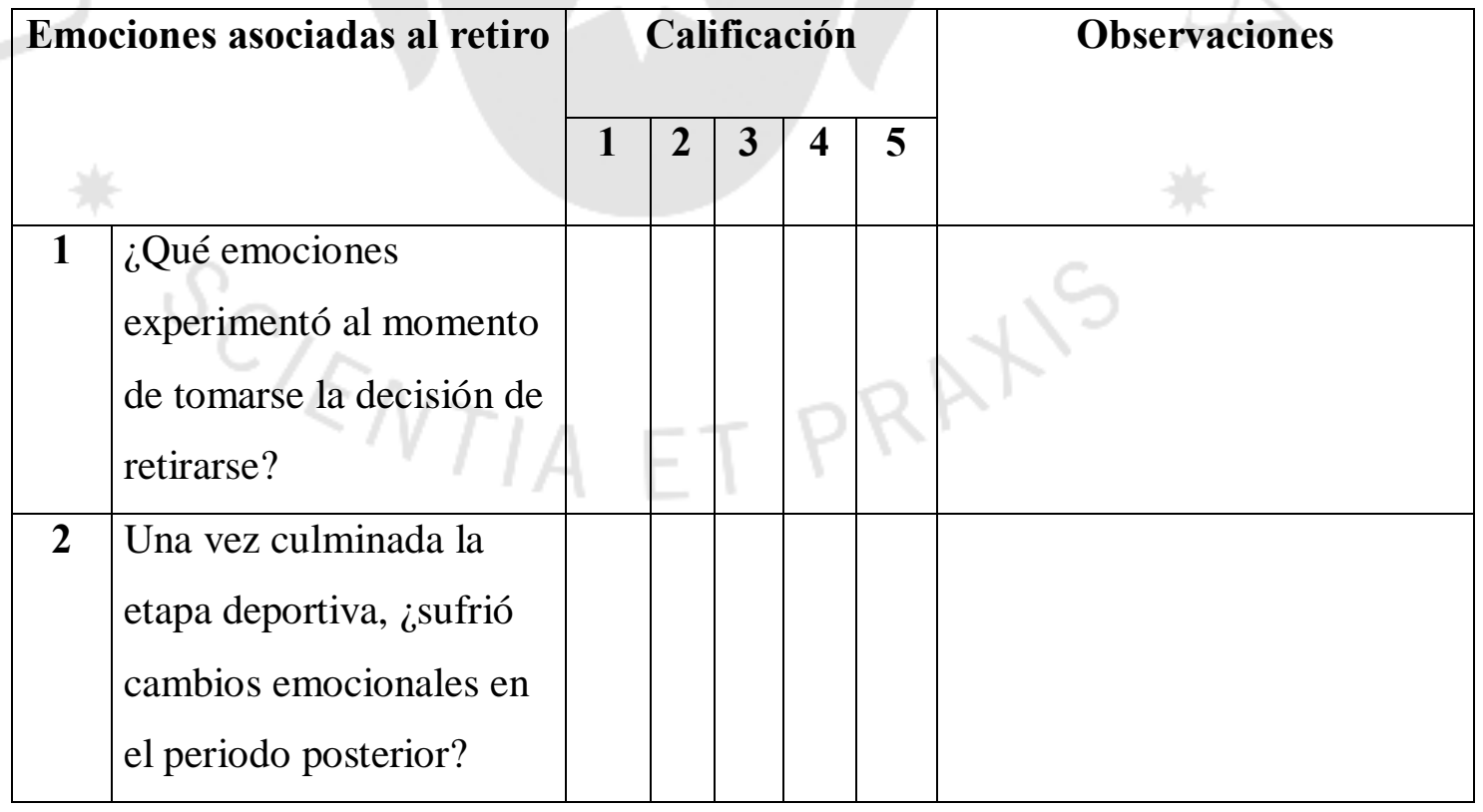




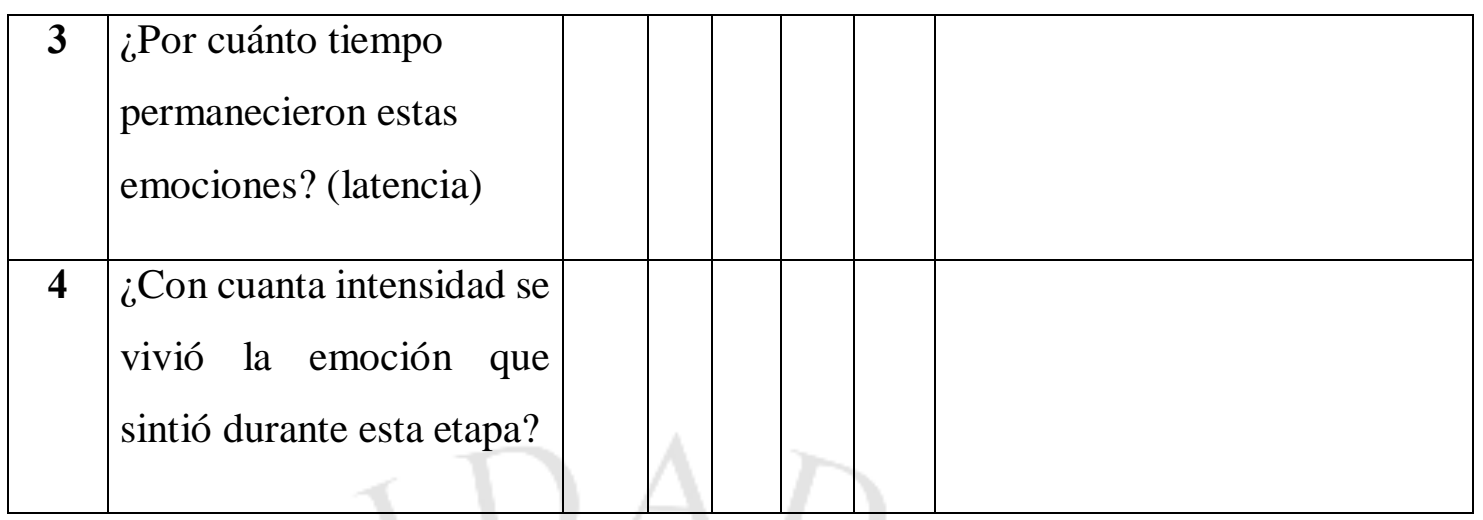

\begin{tabular}{|c|c|c|c|c|c|c|c|}
\hline \multirow{2}{*}{\multicolumn{2}{|c|}{$\begin{array}{c}\text { Pensamientos asociados al } \\
\text { retiro }\end{array}$}} & \multicolumn{5}{|c|}{ Calificación } & \multirow[t]{2}{*}{ Observaciones } \\
\hline & & 1 & 2 & 3 & 4 & 5 & \\
\hline 1 & $\begin{array}{l}\text { ¿Qué significó para usted } \\
\text { el momento de su retiro? }\end{array}$ & & & & & & \\
\hline 2 & $\begin{array}{l}\text { ¿Qué pensamientos } \\
\text { pasaban por su mente } \\
\text { durante ese momento? }\end{array}$ & & & & & & \\
\hline 3 & $\begin{array}{l}\text { ¿Qué significó para usted } \\
\text { ser un deportista } \\
\text { retirado? }\end{array}$ & & & & & & \\
\hline
\end{tabular}

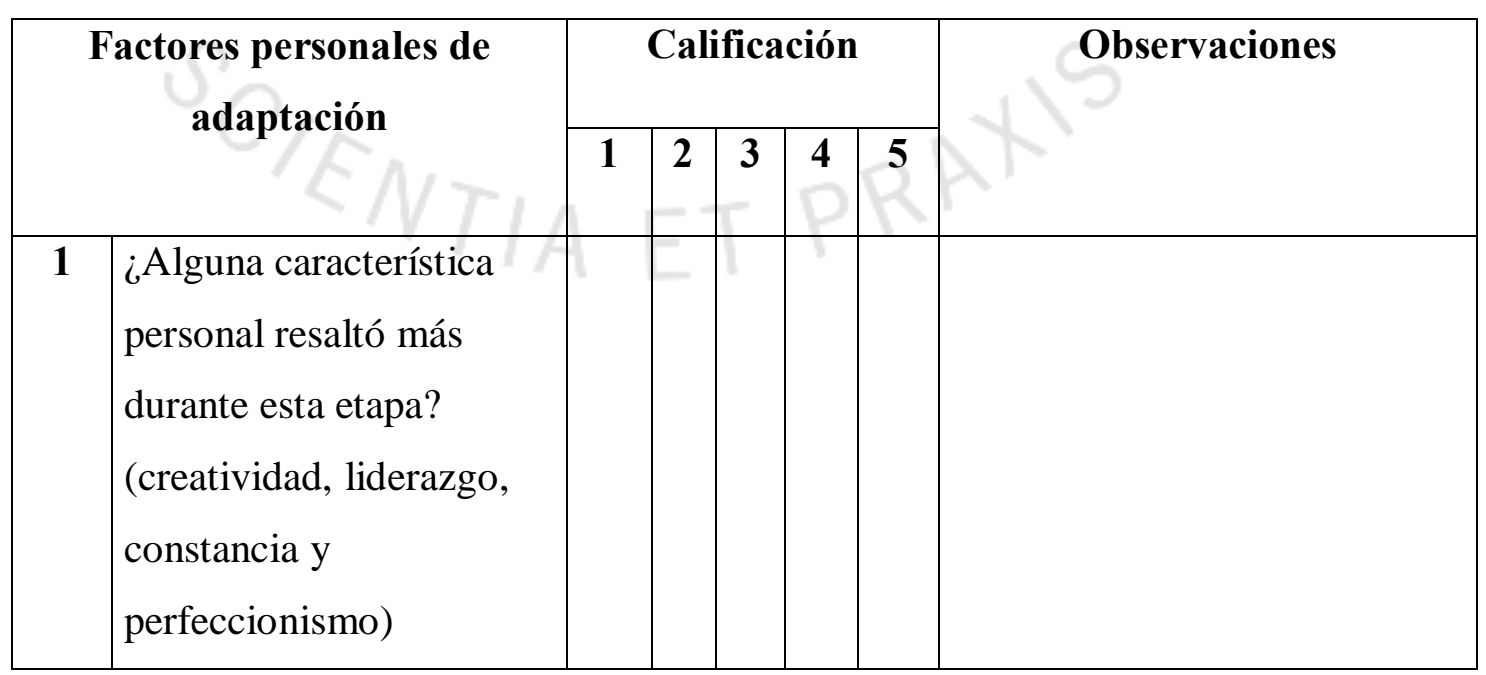




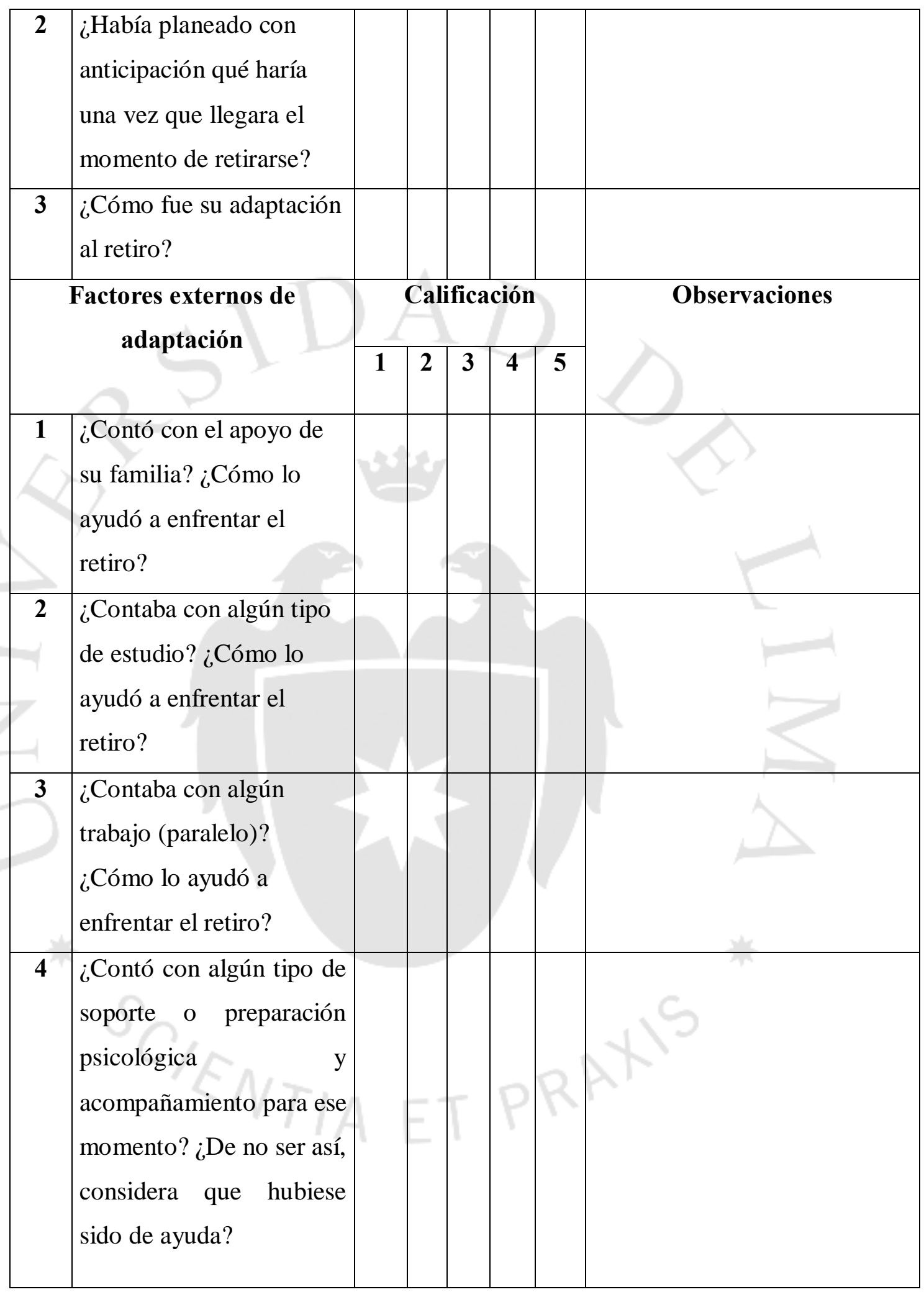




\begin{tabular}{|c|c|c|c|c|c|c|c|}
\hline \multicolumn{2}{|r|}{ Repercusiones del retiro } & \multicolumn{5}{|c|}{ Calificación } & \multirow[t]{2}{*}{ Observaciones } \\
\hline & & 1 & 2 & 3 & 4 & 5 & \\
\hline 1 & $\begin{array}{l}\text { ¿A qué se dedicó luego } \\
\text { de su retiro deportivo? }\end{array}$ & & & & & & \\
\hline 2 & ¿Se sintió satisfecho con & & & & & & \\
\hline & lo que hacía? & & & & & & \\
\hline 3 & $\begin{array}{l}\text { ¿En la actualidad sigue } \\
\text { dedicándose a lo mismo } \\
\text { o ha habido algún } \\
\text { cambio? }\end{array}$ & 3 & -4 & & & & \\
\hline 4 & $\begin{array}{l}\text { ¿De qué manera impactó } \\
\text { el retiro en su situación } \\
\text { económica? }\end{array}$ & & & & & & \\
\hline 5 & $\begin{array}{l}\text { ¿De qué manera impactó } \\
\text { el retiro en su situación } \\
\text { familiar? }\end{array}$ & & & & & & \\
\hline 6 & $\begin{array}{l}\text { ¿El impacto del retiro } \\
\text { tuvo repercusiones en su } \\
\text { vida en el aspecto } \\
\text { personal? ¿De qué } \\
\text { manera? }\end{array}$ & 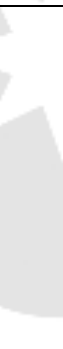 & & & & & \\
\hline 7 & $\begin{array}{l}\text { ¿El impacto del retiro } \\
\text { tuvo repercusiones en su } \\
\text { vida en el aspecto } \\
\text { laboral? ¿De qué } \\
\text { manera? }\end{array}$ & & & & & & \\
\hline 8 & $\begin{array}{l}\text { ¿El impacto del retiro } \\
\text { tuvo repercusiones en su } \\
\text { vida en el aspecto social? } \\
\text { ¿De qué manera? }\end{array}$ & & & & & & \\
\hline
\end{tabular}




\begin{tabular}{|l|l|l|l|l|l|l|l|}
\hline 9 & A nivel general, después & & & & & & \\
del retiro ¿ha sentido & & & & & & \\
satisfacción personal en & & & & & & \\
estos aspectos de su \\
vida?
\end{tabular}

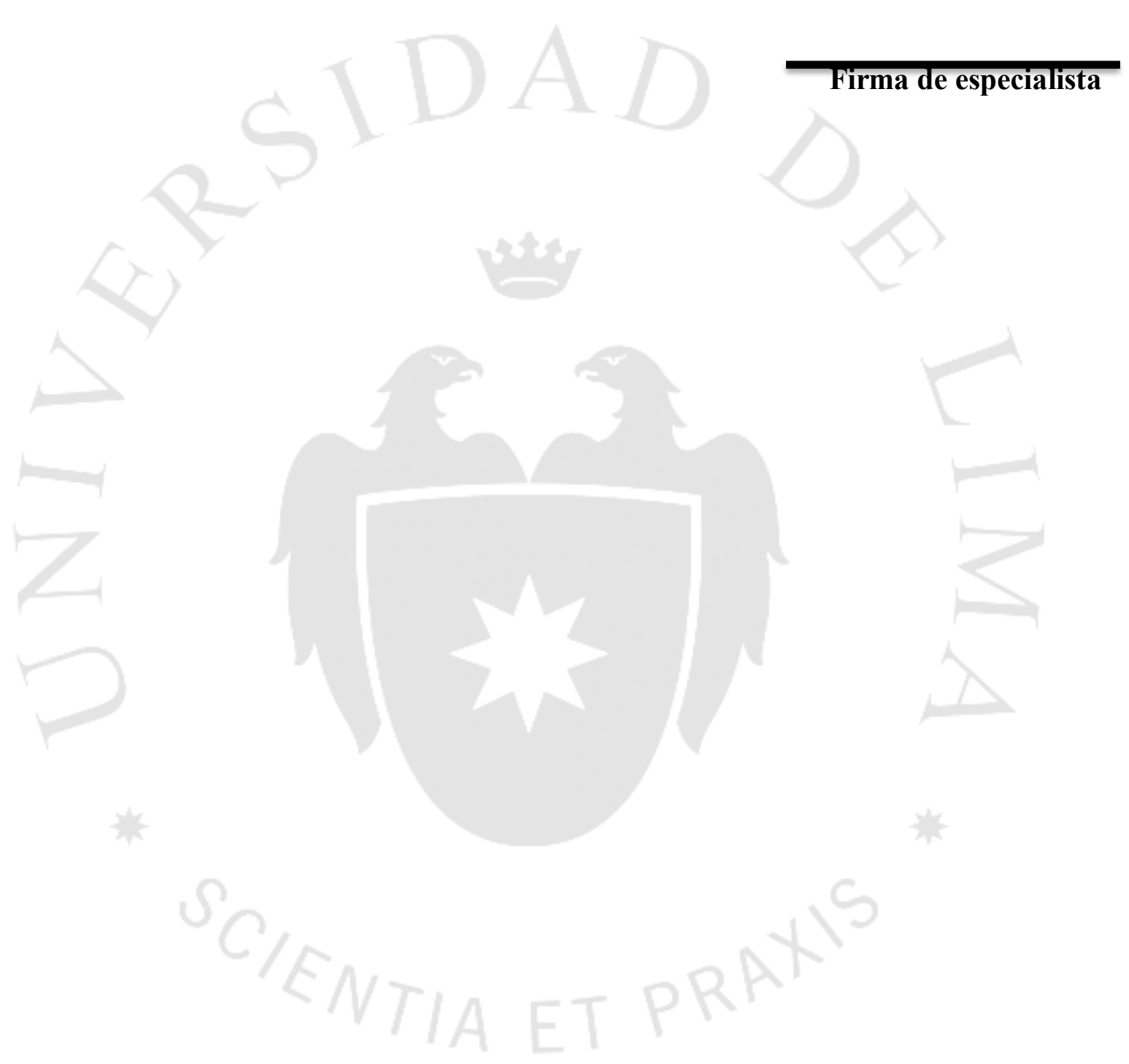




\section{APENDICE 4: SESIÓN DE CREDIBILIDAD DE LOS RESULTADOS}

$\operatorname{Sr}(\mathrm{a})$. Participante,

A través del presente documento se le solicita su colaboración en el proceso de credibilidad de los resultados obtenidos a lo largo de las 10 entrevistas realizadas, en la investigación "La experiencia del retiro en deportistas de alta competencia en Lima".

A continuación se mencionará los principales aspectos a tomar en cuenta durante la entrevista de validación de resultados.

\begin{tabular}{|c|c|}
\hline $\begin{array}{l}\text { Objetivo de la } \\
\text { validación }\end{array}$ & $\begin{array}{l}\text { Verificar la credibilidad del estudio a partir de la devolución de } \\
\text { resultados, de manera que se pueda contrastar la información } \\
\text { obtenida en base a los testimonios de los participantes. }\end{array}$ \\
\hline Participantes & Dos participantes seleccionados de manera aleatoria. \\
\hline Modo de validaci & $\begin{array}{l}\text { Entrevista individual: se busca evaluar la interpretación de sus } \\
\text { propios aportes y los resultados de las } 10 \text { entrevistas realizadas. } \\
\text { Para ello, se le presenta al participante un resumen de la } \\
\text { información que brindó, con algunas citas que mencionaron, de } \\
\text { manera que se pueda conocer si la información fue correctamente } \\
\text { interpretada. Luego se procederá a mostrarle las categorías } \\
\text { construidas en base a los testimonios. Finalmente, se busca que } \\
\text { el participante proporcione nuevos aportes, complementando la } \\
\text { información extraída de sus testimonios. }\end{array}$ \\
\hline
\end{tabular}




\section{Resumen del testimonio}

\section{Aportes del participante}

\begin{tabular}{|l|l|}
\hline CATEGORÍA 1 & Significado Personal del Deporte \\
\hline Sub-Categoría a & Identidad \\
\hline Sub-Categoría b & Éxito \\
\hline Sub-Categoría c & Satisfacción \\
\hline Sub-Categoría d & Dedicación \\
\hline
\end{tabular}

Identidad

- Hay un fuerte vínculo con la disciplina deportiva, forjándose una fuerte relación emocional con el deporte. 
- El vínculo se va desarrollando a lo largo de la carrera.

- Los deportistas consideran su identidad deportiva como la totalidad de su identidad.

- A partir de los testimonios se observa que una fuerte identidad deportiva puede generar que el retiro sea vivido como una experiencia adversa.

Éxito

- Los triunfos alcanzados y reconocimientos se convierten en un aspecto fundamental del deporte.

- Asimismo, la retribución económica, también juega un papel importante en la concepción del éxito, ya que sentían que su esfuerzo era retribuido de alguna manera.

- De esta manera, lo mencionado contribuía a la consolidación de una imagen positiva de sí mismo.

- Es así, que el valor que los deportistas le dan al éxito se convierte en un elemento que puede afectar la autoestima durante el retiro, ya que aparece el temor a dejar de ser reconocidos.

\section{$\underline{\text { Satisfacción }}$}

- El deporte es visto como un medio que le permitió a los atletas mejorar su situación económica, y en algunos casos salir de la pobreza.

- De manera, que el deporte le brindó una oportunidad para optimizar su calidad de vida y la de su familia.

- Esto promueve un fuerte sentimiento de gratitud hacia la disciplina deportiva, generando, aún en el presente emociones positivas.

\section{Dedicación}

- La exigencia del deporte no le permitía realizar a los atletas diversas actividades ajenas a la disciplina deportiva.

- Sin embargo, esto no era visto como un sacrificio, sino era una decisión voluntaria que realizaban los deportistas para poder alcanzar sus objetivos.

- De manera que el deporte se convierte en una actividad exclusiva y en algunos casos excluyentes, relegando otras áreas de sus vidas. 
- En muchos casos, los participantes culminaban la etapa deportiva sin una carrera profesional que los respaldase.

\begin{tabular}{|l|l|}
\hline CATEGORÍA 2 & Causas del Retiro \\
\hline Sub-Categoría a & Retiro Voluntario \\
\hline Sub-Categoría b & Retiro Forzado \\
\hline
\end{tabular}

$\underline{\text { Retiro voluntario }}$

- El retiro puede darse en dos etapas distintas, cuando los atletas se encuentran en la plenitud de su carrera y cuando se encuentran en el ocaso de ésta.

- Hubo quienes se retiraron debido a la impuntualidad en cuanto al pago, lo que deterioraba la relación con los directivos de los equipos, generando insatisfacción e incomodidad, restándole disfrute a la práctica deportiva.

- Por otro lado, otro se retiraron porque era tiempo de realizar otras actividades, siendo ya hora de dar por concluida la carrera deportiva.

- Asimismo, hubo quien se retiró en la cumbre de su carrera al sentir demasiada presión y exigencia por parte de su entorno, lo cual no le dejaba disfrutar la actividad deportiva ni le permitía realizar otras actividades acorde a su edad.

- Frente a ello, se encuentra que la diferencia entre quienes toman la decisión de retirarse libremente y quienes se ven influenciados por las circunstancias, es que la primera no produjo niveles elevados de malestar emocional y facilitó el proceso de transición, en comparación con la segunda, que fue un proceso más doloroso y difícil de enfrentar.

$\underline{\text { Retiro forzado }}$

- Los deportistas se vieron obligados a retirarse por factores físicos o por factores externos.

- Se evidencia que cuando el retiro llega de manera inesperada el evento puede ser más doloroso.

- Sin embargo, tanto el retiro voluntario como el forzado puede afectar negativamente el deportista. 


\begin{tabular}{|l|l|}
\hline CATEGORÍA 3 & Significado Personal del Retiro \\
\hline Sub-Categoría a & Pérdida \\
\hline Sub-Categoría b & $\begin{array}{l}\text { Transición: final o comienzo de una } \\
\text { nueva etapa }\end{array}$ \\
\hline Sub-Categoría c & Continuidad \\
\hline Sub-Categoría d & Equivocación \\
\hline Sub-Categoría e & Satisfacción \\
\hline
\end{tabular}

\section{$\underline{\text { Pérdida }}$}

- Hubo deportistas que tuvieron la sensación de haber perdido algo muy importante, inclusive consideraron el retiro como un duelo.

- Los participantes experimentaron una sensación de pérdida al dejar de lado una costumbre, los beneficios que conlleva ser un deportista de élite, así como alejarse de sus compañeros de equipo.

- El proceso de transición se vuelve más difícil cuando el participante ve el retiro como la pérdida de oportunidades para enmendar algo que "no pudo hacer" o hizo erróneamente durante la carrera, significando el retiro la imposibilidad de corregir ese error. Esto fomenta la aparición de emociones como el arrepentimiento y la frustración.

- Asimismo, el dolor emocional aumenta, cuando hay una pérdida de identidad, experimentando el retiro como un duelo.

Transición: final o comienzo de una etapa

- Hay participantes que experimentaron el retiro como el final de una etapa, al ser parte natural del ciclo vital, siendo momento de asumir otras responsabilidades y roles.

- El retiro no fue experimentado como algo catastrófico, ya que era lo que correspondía a ese momento.

- Esta manera de ver el retiro permitía que los atletas se sintieran tranquilos frente a la decisión de retirarse.

Continuidad

- Los deportistas no vieron el retiro como el final de la vida deportiva, ya que lo continuaron practicando a nivel recreativo o como entrenadores. 
- De esta manera, los deportistas sienten que contribuyen a su deporte, tal vez no de manera directa, pero a través de sus alumnos.

- Asimismo, se observa que la identidad deportiva perdura a través del tiempo, ya que los participantes se continúan considerando deportistas a pesar del retiro.

- Esta visión del retiro les brinda tranquilidad a los atletas, ya que aún se sienten vinculados al deporte.

Equivocación

- La decisión y el motivo de la retirada se convirtieron en una fuente de frustración y arrepentimiento.

- Esta forma de ver el retiro promovió la aparición de emociones negativas, que no facilitaron el proceso de transición; sin embargo, esto no significó que el exatleta se quedara estancado y no empalmara con nuevos proyectos.

\section{$\underline{\text { Satisfacción }}$}

- Los deportistas se llevan un grato recuerdo de su carrera deportiva.

- Actualmente, sienten que su aporte al deporte ha trascendido, ya que continúan siendo reconocidos y recibiendo el cariño de las personas.

\begin{tabular}{|l|l|}
\hline CATEGORÍA 4 & Reacciones frente al retiro \\
\hline Sub-Categoría a & Emociones \\
\hline Sub-Categoría b & Pensamientos \\
\hline
\end{tabular}

\section{$\underline{\text { Emociones }}$}

- El retiro afectó emocionalmente a los participantes, siendo para unos una experiencia cargada de emociones negativas, otros, por el contrario, experimentaron alivio.

- Se observa la predominancia de la ansiedad y tristeza, siendo la segunda, en muchos casos, considerada como depresión.

- Otros sintieron odio, relacionado a la frustración de no poder continuar realizando el deporte que amaban. Asimismo, aparecen emociones de culpa, miedo y nostalgia.

- Se observa que mientras mayor espacio ocupó el deporte en la identidad del atleta, las reacciones emocionales fueron más negativas e intensas. 


\section{$\underline{\text { Pensamientos }}$}

- A algunos deportistas les costó aceptar que había llegado el final de la carrera; de manera que negaban la realidad para así evitar el dolor de reconocer que la carrera deportiva había acabado de manera definitiva.

- Otros consideraron que el retiro era un evento injusto que no debían estar enfrentando todavía.

- Asimismo, hubo atletas que aceptaron la realidad, afrontando el periodo de retiro.

- Por último, algunos deportistas no sabían cómo continuar después de retirarse, qué hacer una vez concluida la carrera deportiva. Esto generaba ansiedad, dificultando el proceso de transición.

\begin{tabular}{|l|l|}
\hline CATEGORÍA 5 & Impacto del retiro \\
\hline Sub-Categoría a & Aspecto Personal \\
\hline Sub-Categoría b & Aspecto Social \\
\hline Sub-Categoría c & Aspecto Económico \\
\hline Sub-Categoría d & Aspecto Familiar \\
\hline
\end{tabular}

\section{$\underline{\text { Aspectos personales }}$}

- Los deportistas que tenían una identidad deportiva elevada, se vieron fuertemente afectados por el retiro, generando problemas emocionales y físicos.

- Algunas de las consecuencias negativas fueron: comer descontroladamente, provocando una fuerte subida de peso, altos niveles de ansiedad y depresión, baja de autoestima, inestabilidad emocional, beber alcohol en exceso, ataques de pánico e insomnio.

- Asimismo, también produjo un impacto negativo, ya que los participantes no tuvieron la oportunidad de pasar por un proceso de desentrenamiento, que permitiera tener una disminución planificada y gradual de la carga física durante el periodo activo, reduciendo así los efectos biológicos al retiro.

- Por otro lado, para uno de los participantes el retiro tuvo un impacto positivo, ya que la atención recibida por los hinchas y los medios de comunicación era agobiante y le generaba malestar. 


\section{Aspecto social}

- Hubo participantes en los que el retiro tuvo un impacto positivo a nivel social, ya que al tener mayor tiempo libre podía pasar más tiempo con sus amigos.

- No obstante, a otros les afecto fuertemente, puesto que la atención del medio cambió completamente una vez que deportista se retiró, de manera que si el atleta había puesto su valor personal entorno a los aplausos, éxito, etc. la etapa de retiro se vuelve más difícil.

\section{Aspecto Económico}

- Para los deportistas que recibían un sueldo, el retiro significo un cambio en sus finanzas y en algunos casos un periodo de inestabilidad económica.

- Hubo también, quienes no se vieron afectados a nivel económico, ya que supieron ahorrar y administrar adecuadamente su dinero.

- A nivel general, ninguno de los participantes paso por un periodo de crisis financiera, ya que todos pudieron estabilizarse y conseguir nuevos empleos.

\section{$\underline{\text { Aspecto Familiar }}$}

- El retiro no impacta solo al deportista de manera individual, sino que también afecta a la familia; puesto que el retiro implicó perder buenas oportunidades, desperdiciar toda inversión de tiempo, esfuerzo y dinero.

- Los familiares se sintieron defraudados, decepcionados y molestos, incluso llegando a ocasionar conflicto y dañar las relaciones entre el deportista y su familia.

- Asimismo, con el retiro, los familiares de los deportistas dejaron de recibir diversos beneficios, como viajes y una buena posición económica.

\begin{tabular}{|l|l|}
\hline CATEGORÍA 6 & $\begin{array}{l}\text { Factores que condicionan la } \\
\text { adaptación }\end{array}$ \\
\hline Sub-Categoría a & Recursos Individuales \\
\hline Sub-Categoría b & Recursos Sociales \\
\hline
\end{tabular}

$\underline{\text { Recursos Individuales }}$ 
- Los atletas contaban con competencias personales (liderazgo, perseverancia, resiliencia, etc.) que les permitieron adaptarse al retiro.

- Las creencias religiosas ayudaron a uno de los atletas a sentirse tranquilo, ya que sentía que un ser superior lo protegía, buscando su bienestar.

- Los deportistas que planificaron con anticipación qué harían después del retiro tuvieron una transición más corta y fluida, ya que les brindó una sensación de control sobre la situación.

- La estabilidad económica proporcionó tranquilidad a los deportistas.

- El tener estudios académicos le permitió al atleta adaptarse mejor al retiro, ya que pudieron desarrollar otras habilidades y abrirse paso en el mundo laboral.

Empalmar con actividades laborales, deportivas o de interés personal, le permitió a los atletas evadir el malestar emocional.

\section{$\underline{\text { Recursos Sociales }}$}

- Los atletas que contaron con el apoyo de su familia se sintieron reconfortados, ya que ésta brindo un espacio de apoyo incondicional.

- Asimismo, los amigos eran un elemento de distracción, en los que se podían apoyar los deportistas y experimentar emociones positivas.

- Por otro lado, el reconocimiento de las personas, a pesar del retiro, genera satisfacción personal.

- Hay una ausencia total de soporte psicológico durante el retiro. Frente a ello, algunos consideran que era necesario recibir el apoyo de un psicólogo; no obstante, hubo quienes mencionaron que no era algo necesario, ya que bastaba con sus propios recursos.

\begin{tabular}{|l|l|}
\hline CATEGORÍA 7 & Satisfacción Actual \\
\hline Sub-Categoría a & Alto nivel de satisfacción \\
\hline Sub-Categoría b & Bajo nivel de satisfacción \\
\hline
\end{tabular}

$\underline{\text { Nivel alto de satisfacción }}$

- El alto nivel de satisfacción con la vida actual está relacionado a las nuevas actividades que realizan o a los nuevos roles que desempeñan. 
- Los deportistas recuerdan con gratitud el pasado, ya que el deporte les ha brindado diversas oportunidades laborales, competencias personales, habilidades y reconocimientos hasta hoy en día.

Bajo nivel de satisfacción

- Se observa que en el ámbito laboral, para algunos deportistas, hay un bajo nivel de satisfacción, ya que nunca sintieron el mismo disfrute que al realizar la actividad deportiva.

\section{Aportes del participante}

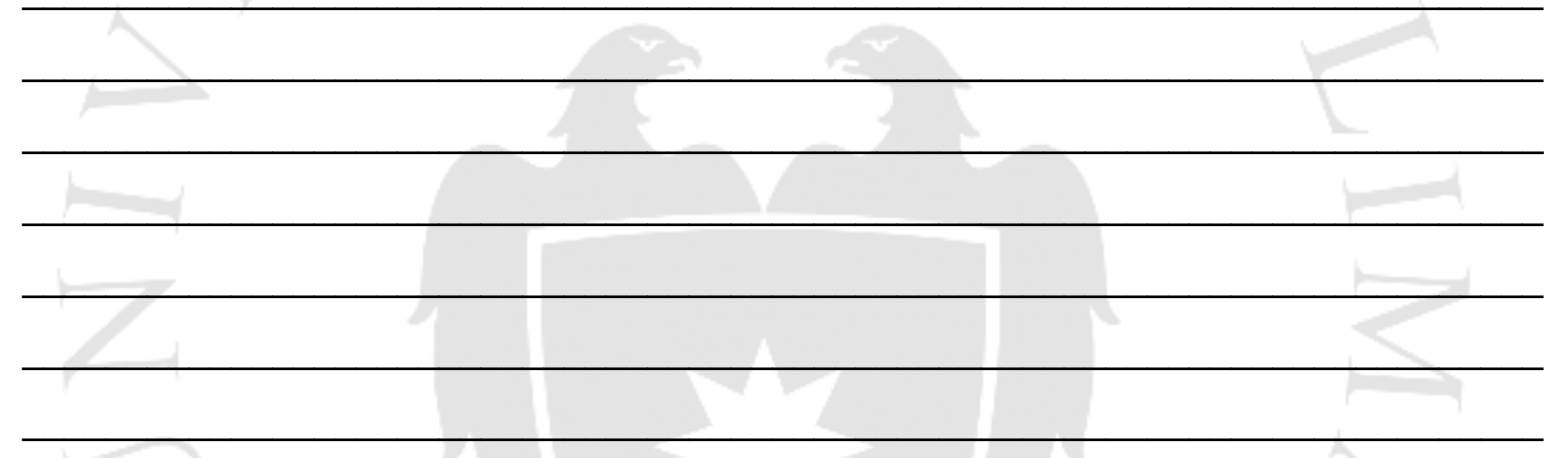




\section{APENDICE 5: FICHA DE DATOS PERSONAL}

\begin{tabular}{|l|l|}
\hline Nombre & \\
\hline Fecha de nacimiento & \\
\hline Edad & \\
\hline Disciplina deportiva & \\
\hline Edad de iniciación en el deporte & \\
\hline Duración de la carrera deportiva & \\
\hline Estudios superiores & \\
\hline Trabajo actual & \\
\hline
\end{tabular}




\section{APENDICE 6: LIBRO DE CÓDIGOS}

\begin{tabular}{|l|l|}
\hline CATEGORÍA 1 & Significado Personal del Deporte \\
\hline Sub-Categoría a & Identidad \\
\hline Sub-Categoría b & Éxito \\
\hline Sub-Categoría c & Satisfacción \\
\hline Sub-Categoría d & Dedicación \\
\hline
\end{tabular}

\begin{tabular}{|l|l|}
\hline CATEGORÍA 2 & Causas del Retiro \\
\hline Sub-Categoría a & Retiro Voluntario \\
\hline Sub-Categoría b & Retiro Forzado \\
\hline
\end{tabular}

\begin{tabular}{|l|l|}
\hline CATEGORÍA 3 & Significado Personal del Retiro \\
\hline Sub-Categoría a & Pérdida \\
\hline Sub-Categoría b & $\begin{array}{l}\text { Transición: final o comienzo de una } \\
\text { nueva etapa }\end{array}$ \\
\hline Sub-Categoría c & Continuidad \\
\hline Sub-Categoría d & Equivocación \\
\hline Sub-Categoría e & Satisfacción \\
\hline & \\
\hline CATEGORÍA 4 & Reacciones frente al retiro \\
\hline Sub-Categoría a & Emociones \\
\hline Sub-Categoría b & Pensamientos \\
\hline
\end{tabular}

\begin{tabular}{|l|l|}
\hline CATEGORÍA 5 & Impacto del retiro \\
\hline Sub-Categoría a & Aspecto Personal \\
\hline Sub-Categoría b & Aspecto Social \\
\hline Sub-Categoría c & Aspecto Económico \\
\hline Sub-Categoría d & Aspecto Familiar \\
\hline
\end{tabular}

\begin{tabular}{|l|l|}
\hline CATEGORÍA 6 & $\begin{array}{l}\text { Factores que condicionan la } \\
\text { adaptación }\end{array}$ \\
\hline Sub-Categoría a & Recursos Individuales \\
\hline Sub-Categoría b & Recursos Sociales \\
\hline
\end{tabular}

\begin{tabular}{|l|l|}
\hline CATEGORÍA 7 & Satisfacción Actual \\
\hline Sub-Categoría a & Alto nivel de satisfacción \\
\hline Sub-Categoría b & Bajo nivel de satisfacción \\
\hline
\end{tabular}




\section{APENDICE 7: CATEGORIZACIÓN}

\begin{tabular}{|c|c|c|c|c|c|c|c|c|c|c|c|}
\hline Categoría & Subcat. & Fut. & Nad. & Nad. & Vol. & Box. & Box. & Fut. & Vol. & Nad. & Fut. \\
\hline \multirow{4}{*}{$\begin{array}{l}\text { Significado } \\
\text { persona del } \\
\text { deporte }\end{array}$} & Identidad & $\begin{array}{l}\text { El fútbol es } \\
\text { mi } \\
\text { pasión... } \\
\text { mi sueño. }\end{array}$ & $\begin{array}{l}\text { De todas } \\
\text { maneras era } \\
\text { parte de mi } \\
\text { identidad. }\end{array}$ & $\begin{array}{l}\text { Era mi } \\
\text { vida, } \\
\text { bueno } \\
\text { hasta ahora } \\
\text { sigue } \\
\text { siendo mi } \\
\text { vida, por } \\
\text { eso sigo } \\
\text { enseñando. } \\
\text { Yo no veía } \\
\text { mi vida sin } \\
\text { la natación }\end{array}$ & $\begin{array}{l}\text { Es mi vida, } \\
\text { si volviera } \\
\text { a nacer } \\
\text { volvería a } \\
\text { ser } \\
\text { voleibolist } \\
\text { a... Mi } \\
\text { vida fue, } \\
\text { es y será el } \\
\text { vóley... }\end{array}$ & $\begin{array}{l}\text { Me sentía } \\
\text { ubicado, } \\
\text { me iba } \\
\text { bien, } \\
\text { sentía } \\
\text { que } \\
\text { pertenecí } \\
\text { a ahí. Sí } \\
\text { claro que } \\
\text { era parte } \\
\text { de mi } \\
\text { identidad }\end{array}$ & $\begin{array}{l}\text { Todo es } \\
\text { boxeo. } \\
\text { Es parte } \\
\text { de mi } \\
\text { identida } \\
\text { d porque } \\
\text { yo me } \\
\text { consider } \\
\text { o un } \\
\text { luchador } \\
\end{array}$ & $\begin{array}{l}\text { A mí me } \\
\text { encantaba, } \\
\text { era parte de } \\
\text { mi vida... } \\
\text { Creo que } \\
\text { nací para } \\
\text { eso... Nací } \\
\text { para el } \\
\text { futbol. } \\
\text { Mi vida era } \\
\text { el futbol }\end{array}$ & $\begin{array}{l}\text { Sentía que } \\
\text { era parte de } \\
\text { mi } \\
\text { personalida } \\
\text { d el ser } \\
\text { deportista }\end{array}$ & & \\
\hline & Éxito & $\begin{array}{l}\text { Sentía una } \\
\text { felicidad } \\
\text { enorme de } \\
\text { poder } \\
\text { lograr que } \\
\text { tu pasión, } \\
\text { no solo sea } \\
\text { una } \\
\text { satisfacción } \\
\text { persona, } \\
\text { sino que } \\
\text { económica } \\
\text { mente te } \\
\text { retribuía. }\end{array}$ & 2 & & $\begin{array}{l}\text {...fui la } \\
\text { mejor } \\
\text { jugadora } \\
\text { del mundo, } \\
\text { olímpica... } \\
\text { campeona } \\
\text { mundial de } \\
\text { clubs, creo } \\
\text { que fui la } \\
\text { única } \\
\text { jugando en } \\
\text { el } \\
\text { extranjero. }\end{array}$ & & & $\begin{array}{l}\text { Si no } \\
\text { hubiera } \\
\text { sido por el } \\
\text { futbol nadie } \\
\text { me } \\
\text { conocería } \\
\text {... Para mí } \\
\text { ha sido un } \\
\text { abre } \\
\text { puertas... }\end{array}$ & & 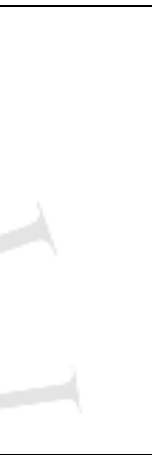 & $\begin{array}{l}\text { Jugué en } \\
\text { Independie } \\
\text { nte... Salí } \\
\text { campeón de } \\
\text { la Copa } \\
\text { Libertadore } \\
\text { s, salí } \\
\text { campeón de } \\
\text { la Copa } \\
\text { Interameric } \\
\text { ana. }\end{array}$ \\
\hline & $\begin{array}{l}\text { Satisfacci } \\
\text { ón }\end{array}$ & $\begin{array}{l}\text { Mi } \\
\text { ilusión... } \\
\text { siempre fue } \\
\text { sacar a mi } \\
\text { familia } \\
\text { adelante... } \\
\text { y lo logré... }\end{array}$ & & $\begin{array}{l}\text { Para mí es } \\
\text { lo máximo, } \\
\text { porque } \\
\text { muy } \\
\text { pocas } \\
\text { personas } \\
\text { pueden } \\
\text { hacer } \\
\text { deporte } \\
\text { como yo lo } \\
\text { hice... }\end{array}$ & $\begin{array}{l}\text {... para mí, } \\
\text { el vóley } \\
\text { fue lo } \\
\text { mejor que } \\
\text { me pasó en } \\
\text { la vida... } \\
\text { en el } \\
\text { momento } \\
\text { en que } \\
\text { jugaba yo } \\
\text { era } \\
\text { admirada } \\
\text {... yo era } \\
\text { alguien } \\
\text { especial. }\end{array}$ & $\begin{array}{l}\text { Admiras } \\
\text { a aspirar, } \\
\text { quieres } \\
\text { ser más } \\
\text { en esa } \\
\text { rama. }\end{array}$ & $\begin{array}{l}\text { Te } \\
\text { enseña a } \\
\text { vivir, te } \\
\text { da } \\
\text { ejemplos } \\
\text { de vida. } \\
\text { Para mí } \\
\text { el boxeo } \\
\text { fue el } \\
\text { que me } \\
\text { arregló } \\
\text { la vida. }\end{array}$ & $\begin{array}{l}\text { Por el } \\
\text { futbol } \\
\text { conozco } \\
\text { tanto, me } \\
\text { dio todo. }\end{array}$ & & $\begin{array}{l}\text { La verdad } \\
\text { es que no } \\
\text { cambiaría } \\
\text { por nada el } \\
\text { haber sido } \\
\text { nadadora. } \\
\text { Ha sido } \\
\text { siempre } \\
\text { muy } \\
\text { gratificante. }\end{array}$ & $\begin{array}{l}\text { El futbol la } \\
\text { verdad me } \\
\text { ha dado } \\
\text { muchas } \\
\text { satisfaccion } \\
\text { es. }\end{array}$ \\
\hline & $\begin{array}{l}\text { Dedicaci } \\
\text { ón }\end{array}$ & $\begin{array}{l}\text { De joven } \\
\text { yo me } \\
\text { dedicaba de } \\
\text { lleno al } \\
\text { futbol, era } \\
\text { mi vida, } \\
\text { estaba } \\
\text { dedicado } \\
\text { completam } \\
\text { ente... } \\
\text { ingrese a la } \\
\text { san Martín } \\
\text { a estudiar } \\
\text { derecho, lo } \\
\text { deje por el } \\
\text { futbol... } \\
\text { todo iba } \\
\text { dejando. }\end{array}$ & $\begin{array}{l}\text { Me } \\
\text { levantaba e } \\
\text { iba nadar, } \\
\text { luego iba al } \\
\text { colegio, a } \\
\text { veces no } \\
\text { iba al } \\
\text { colegio. } \\
\text { Salía del } \\
\text { colegio y } \\
\text { me iba a } \\
\text { nadar, } \\
\text { gimnasio, } \\
\text { llegaba a } \\
\text { mi casa } \\
\text { comía. }\end{array}$ & $\begin{array}{l}\text { No era un } \\
\text { compleme } \\
\text { nte, era } \\
\text { algo a lo } \\
\text { que me } \\
\text { dedicaba } \\
\text { de lleno. }\end{array}$ & $\begin{array}{l}\text { Había } \\
\text { sacrificios } \\
\text { que uno } \\
\text { tenía que } \\
\text { hacer, pero } \\
\text { cuando } \\
\text { uno dice } \\
\text { sacrificio, } \\
\text { yo no me } \\
\text { arrepiento. } \\
\text { Era un } \\
\text { sacrificio } \\
\text { dulce, rico } \\
\text { porque al } \\
\text { día } \\
\text { siguiente si } \\
\text { yo dormía } \\
\text { bien } \\
\text { jugaba } \\
\text { bien. }\end{array}$ & & & $\begin{array}{l}\text { Yo dejaba } \\
\text { todo por el } \\
\text { futbol. Era } \\
\text { chico, había } \\
\text { fiestas, pero } \\
\text { no eran tan } \\
\text { gratas } \\
\text { como } \\
\text { correr atrás } \\
\text { de la } \\
\text { pelota...Yo } \\
\text { para el } \\
\text { futbol tenía } \\
\text { todo mi } \\
\text { tiempo }\end{array}$ & $\begin{array}{l}\text { Es fuerte, } \\
\text { es } \\
\text { sacrificio, } \\
\text { es súper } \\
\text { cansado, es } \\
\text { mucho } \\
\text { sacrificio. }\end{array}$ & $\begin{array}{l}\text { Recuerdo } \\
\text { siempre } \\
\text { haber } \\
\text { tenido que } \\
\text { levantarme } \\
\text { muy } \\
\text { temprano, a } \\
\text { las } 5 \text { am, } \\
\text { para poder } \\
\text { ir a entrenar } \\
\text { y luego ir al } \\
\text { colegio e ir } \\
\text { directament } \\
\text { e a mis } \\
\text { entrenamie } \\
\text { ntos... }\end{array}$ & $\begin{array}{l}\text { Ya } \\
\text { comencé a } \\
\text { tomarlo } \\
\text { como una } \\
\text { profesión, } \\
\text { ya me } \\
\text { dediqué } \\
\text { enterament } \\
\text { e al futbol. }\end{array}$ \\
\hline
\end{tabular}




\begin{tabular}{|c|c|c|c|c|c|c|c|c|c|c|c|}
\hline \multirow[t]{2}{*}{$\begin{array}{l}\text { Causa del } \\
\text { retiro }\end{array}$} & $\begin{array}{l}\text { Voluntari } \\
\text { o }\end{array}$ & $\begin{array}{l}\text { Decidí } \\
\text { retirarme } \\
\text { por el } \\
\text { abuso que } \\
\text { había con } \\
\text { los } \\
\text { futbolistas, } \\
\text { en los } \\
\text { últimos } \\
\text { años... } \\
\text { había una } \\
\text { informalida } \\
\text { d... no } \\
\text { pagaba, no } \\
\text { te respetaba } \\
\text { los } \\
\text { contratos... } \\
\text { me paraba } \\
\text { peleando }\end{array}$ & $\begin{array}{l}\text { En 5to de } \\
\text { media les } \\
\text { dije a mis } \\
\text { papás: ya } \\
\text { no aguanto. } \\
\text { Me aburrí y } \\
\text { dije: hasta } \\
\text { acá no } \\
\text { más... Me } \\
\text { harte, tenía } \\
\text { mucha } \\
\text { presión.... }\end{array}$ & & & & & $\begin{array}{l}\text { Bueno } \\
\text { como en } \\
\text { toda } \\
\text { disciplina } \\
\text { deportiva, } \\
\text { esta tiene } \\
\text { su tiempo. } \\
\text { Ya la edad. }\end{array}$ & & $\begin{array}{l}\text { Me retiré } \\
\text { por un tema } \\
\text { de estudios } \\
\text { y de edad. } \\
\text { A me } \\
\text { tocaba } \\
\text { empezar la } \\
\text { universidad } \\
\text {,y } \\
\text { definitivam } \\
\text { ente no iba } \\
\text { a poder } \\
\text { estudiar si } \\
\text { es que } \\
\text { continuaba } \\
\text { con el ritmo } \\
\text { de la } \\
\text { natación. }\end{array}$ & \\
\hline & Forzado & & & $\begin{array}{l}\text { Me retiro } \\
\text { debido a } \\
\text { que salí } \\
\text { embarazad } \\
\text { a. }\end{array}$ & $\begin{array}{l}\text { Mi rodilla } \\
\text { dijo "hasta } \\
\text { acá" ... Yo } \\
\text { no tuve } \\
\text { opción, } \\
\text { tuve que } \\
\text { hacerlo. }\end{array}$ & $\begin{array}{l}\text { Los } \\
\text { administr } \\
\text { adores... } \\
\text { No me } \\
\text { tomaron } \\
\text { en } \\
\text { cuenta... }\end{array}$ & $\begin{array}{l}\text { Un } \\
\text { factor } \\
\text { económi } \\
\text { co... ya } \\
\text { tenía } \\
\text { familia } \\
\text {... }\end{array}$ & & $\begin{array}{l}\text { ya te das } \\
\text { cuenta que } \\
\text { no estás en } \\
\text { los } \\
\text { planes... }\end{array}$ & & $\begin{array}{l}\text { los } \\
\text { directivos } \\
\text { me } \\
\text { dijeron... } \\
\text { juega solo } \\
\text { hasta este } \\
\text { año... } \\
\end{array}$ \\
\hline \multirow{3}{*}{$\begin{array}{l}\text { Significado } \\
\text { del retiro }\end{array}$} & Pérdida & $\begin{array}{l}\text { El día que } \\
\text { decidí } \\
\text { retirarme } \\
\text { me metí a } \\
\text { mi cuarto y } \\
\text { lloré toda la } \\
\text { noche... de } \\
\text { la noche a } \\
\text { la mañana, } \\
\text { lo cortas y } \\
\text { se va... Es } \\
\text { una etapa } \\
\text { de duelo... } \\
\text { nuestra } \\
\text { esencia es } \\
\text { estar en la } \\
\text { cancha y } \\
\text { patear. }\end{array}$ & $\begin{array}{l}\text { Sí, es una } \\
\text { pérdida } \\
\text { total, por } \\
\text { eso yo, } \\
\text { después de } \\
8 \text { años, } \\
\text { empecé a } \\
\text { nadar de } \\
\text { nuevo. }\end{array}$ & & $\begin{array}{l}\text { Horrible, } \\
\text { horrible... } \\
\text { mi retiro } \\
\text { fue muy } \\
\text { duro... yo } \\
\text { entré con } \\
\text { tal } \\
\text { desesperac } \\
\text { ión, } \\
\text { desanimo } \\
\text { total, que } \\
\text { me } \\
\text { abandoné } \\
\ldots \text {.. ahí } \\
\text { acepté que } \\
\text { uno puede } \\
\text { morir por } \\
\text { algo o por } \\
\text { alguien... }\end{array}$ & & & $\begin{array}{l}\text { Sientes que } \\
\text { te quitan } \\
\text { algo... } \\
\text { Era dejar } \\
\text { algo muy } \\
\text { querido }\end{array}$ & $\begin{array}{l}\text { Es como un } \\
\text { luto... yo sí } \\
\text { necesité } \\
\text { mucho } \\
\text { apoyo de } \\
\text { mi familia, } \\
\text { y ni aun } \\
\text { así... } \\
\text { Yo sí sentí } \\
\text { que una } \\
\text { parte de mí } \\
\text { se moría. }\end{array}$ & + & $\begin{array}{l}\text { Una } \\
\text { pérdida de } \\
\text { una } \\
\text { costumbre, } \\
\text { de algo que } \\
\text { es habitual, } \\
\text { como si } \\
\text { perdieras } \\
\text { un } \\
\text { trabajo... } \\
\text { donde } \\
\text { tienes tu } \\
\text { círculo de } \\
\text { amigos, las } \\
\text { personas } \\
\text { que te } \\
\text { atienden... }\end{array}$ \\
\hline & $\begin{array}{l}\text { Transició } \\
\mathrm{n} \text { : } \\
\text { comienzo } \\
\text { o final de } \\
\text { una etapa }\end{array}$ & $\frac{1}{2}$ & & $\begin{array}{l}\text { Yo lo vi } \\
\text { como el } \\
\text { inicio de } \\
\text { otra } \\
\text { etapa... } \\
\text { empecé } \\
\text { una etapa } \\
\text { con mi } \\
\text { hija... veía } \\
\text { que podía } \\
\text { tomar otro } \\
\text { rumbo. }\end{array}$ & & $\begin{array}{l}\text { Me da } \\
\text { chance } \\
\text { de tener } \\
\text { otra } \\
\text { vocación } \\
\text {.. La } \\
\text { decisión } \\
\text { de } \\
\text { retirarme } \\
\text { significó } \\
\text { comenzar } \\
\text { algo } \\
\text { nuevo. }\end{array}$ & & $\begin{array}{l}\text { Es una } \\
\text { etapa que te } \\
\text { lo ordena } \\
\text { los años } \\
\text { nada más, } \\
\text { es lo que } \\
\text { sigue. }\end{array}$ & & $\begin{array}{l}\text { Si lo } \\
\text { extrañé, } \\
\text { pero no } \\
\text { diría que } \\
\text { fue como } \\
\text { que perdí } \\
\text { algo, sino } \\
\text { lo tome } \\
\text { como el } \\
\text { continuar } \\
\text { con mi } \\
\text { vida... Era } \\
\text { lo que } \\
\text { tocaba. }\end{array}$ & \\
\hline & $\begin{array}{l}\text { Sentido } \\
\text { de } \\
\text { continuid } \\
\text { ad }\end{array}$ & $\begin{array}{l}\text { Yo me } \\
\text { retiré e hice } \\
\text { todo el } \\
\text { tema de la } \\
\text { gremiación } \\
\text { y a la par } \\
\text { puse una } \\
\text { academia } \\
\text { de fútbol... } \\
\text { Yo todavía }\end{array}$ & $\begin{array}{l}\text { Me da } \\
\text { nostalgia, } \\
\text { por eso me } \\
\text { metí a } \\
\text { nadar, a } \\
\text { competir de } \\
\text { nuevo, no } \\
\text { ya en el } \\
\text { level, } \\
\text { porque el }\end{array}$ & & $\begin{array}{l}\text { No, yo no } \\
\text { me siento } \\
\text { una } \\
\text { deportista } \\
\text { retirada, } \\
\text { creo que } \\
\text { nunca va a } \\
\text { existir eso } \\
\text { en mi } \\
\text { cabeza. }\end{array}$ & $\begin{array}{l}\text { Me da } \\
\text { chance } \\
\text { de } \\
\text { aportar al } \\
\text { deporte, } \\
\text { en este } \\
\text { caso } \\
\text { dirijo mi } \\
\text { academia }\end{array}$ & $\begin{array}{l}\text {...siemp } \\
\text { re estuve } \\
\text { ligado al } \\
\text { boxeo... } \\
\text { Mis } \\
\text { compañe } \\
\text { ros dicen } \\
\text { que son } \\
\text { exboxea } \\
\text { dores, } \\
\end{array}$ & & $\begin{array}{l}\text { Me } \\
\text { considero } \\
\text { aun } \\
\text { deportista, } \\
\text { siempre } \\
\text { hasta que } \\
\text { tenga } 90 \text { o } \\
100 \text { años, } \\
\text { voy a ser }\end{array}$ & & \\
\hline
\end{tabular}




\begin{tabular}{|c|c|c|c|c|c|c|c|c|c|c|c|}
\hline & & $\begin{array}{l}\text { me } \\
\text { considero } \\
\text { deportista. }\end{array}$ & $\begin{array}{l}\text { tiempo no } \\
\text { me da. }\end{array}$ & & $\begin{array}{l}\text { Retirada de } \\
\text { las canchas } \\
\text { de alta } \\
\text { competenc } \\
\text { ia es una } \\
\text { cosa y } \\
\text { retirada del } \\
\text { deporte } \\
\text { nunca. }\end{array}$ & $\begin{array}{l}\text { Entrenar } \\
\text { gente y } \\
\text { por ahí } \\
\text { captar } \\
\text { algún } \\
\text { valor que } \\
\text { quiera } \\
\text { entrenar } \\
\text { y poder } \\
\text { explotarl } \\
\text { o. }\end{array}$ & $\begin{array}{l}\text { yo no .... } \\
\text { yo voy a } \\
\text { morir } \\
\text { siendo } \\
\text { boxeado } \\
\text { r. }\end{array}$ & & $\begin{array}{l}\text { una vieja } \\
\text { deportista. }\end{array}$ & & \\
\hline & $\begin{array}{l}\text { Equivoca } \\
\text { ción }\end{array}$ & & $\begin{array}{l}\text { Me da } \\
\text { bastante } \\
\text { rabia } \\
\text { haberme } \\
\text { retirado... } \\
\text { Yo me } \\
\text { arrepiento } \\
\text {... es una } \\
\text { de las } \\
\text { peores } \\
\text { decisiones } \\
\text { que he } \\
\text { podido } \\
\text { tomar. }\end{array}$ & & $\begin{array}{l}\text { Me echaba } \\
\text { la culpa } \\
\text { por no } \\
\text { haber } \\
\text { seguido las } \\
\text { indicacion } \\
\text { es de mis } \\
\text { médicos. }\end{array}$ & & & & & & \\
\hline & $\begin{array}{l}\text { Satisfacci } \\
\text { ón }\end{array}$ & $\begin{array}{l}\text { Me siento } \\
\text { orgulloso } \\
\text { de haber } \\
\text { podido ser } \\
\text { futbolista, } \\
\text { porque } \\
\text { muchos } \\
\text { chicos a } \\
\text { veces no se } \\
\text { atreven a } \\
\text { soportar ese } \\
\text { sacrificio... }\end{array}$ & $\begin{array}{l}\text { Siento } \\
\text { bastante } \\
\text { orgullo de } \\
\text { haber } \\
\text { logrado lo } \\
\text { que he } \\
\text { logrado. }\end{array}$ & & $\begin{array}{l}\text { si hubiera } \\
\text { podido } \\
\text { seguir } \\
\text { jugando lo } \\
\text { hubiera } \\
\text { hecho y } \\
\text { hubiera } \\
\text { perdido mi } \\
\text { puesto } \\
\text { como } \\
\text { mejor } \\
\text { jugadora... } \\
\text { el destino } \\
\text { sabe, me } \\
\text { retiré en lo } \\
\text { más alto... }\end{array}$ & & & $\begin{array}{l}\text { Este } \\
\text { deporte me } \\
\text { trajo } \\
\text { solamente } \\
\text { felicidad... } \\
\text { Me } \\
\text { permitió } \\
\text { tener cosas } \\
\text { y todo lo } \\
\text { demás... }\end{array}$ & & & $\begin{array}{l}\text { Yo creo } \\
\text { que el } \\
\text { reconocimi } \\
\text { ento que } \\
\text { tengo a } \\
\text { veces de la } \\
\text { gente me } \\
\text { hacen } \\
\text { pensar y } \\
\text { creer que el } \\
\text { tiempo que } \\
\text { me dediqué } \\
\text { a lo que } \\
\text { hice, lo } \\
\text { hice bien... }\end{array}$ \\
\hline \multirow[t]{2}{*}{$\begin{array}{l}\text { Reacciones } \\
\text { frente al } \\
\text { retiro }\end{array}$} & $\begin{array}{l}\text { Emocion } \\
\text { es }\end{array}$ & $\begin{array}{l}\text { Estaba } \\
\text { triste, } \\
\text { nostalgia. }\end{array}$ & $\begin{array}{l}\text { Me volví } \\
\text { muy } \\
\text { ansiosa, } \\
\text { depresión } \\
\ldots . \\
\text { Estaba...in } \\
\text { estable } \\
\text { emocional } \\
\text { mente. }\end{array}$ & $\begin{array}{l}\text {... cuando } \\
\text { salí } \\
\text { embarazad } \\
\text { a... por un } \\
\text { momento } \\
\text { sentí } \\
\text { alivio... Al } \\
\text { inicio fue } \\
\text { un poco } \\
\text { triste }\end{array}$ & $\begin{array}{l}\text { Frustración } \\
\text {, odio. Es } \\
\text { entre } \\
\text { aceptar y } \\
\text { no } \\
\text { aceptar... } \\
\text { Nadie sabe } \\
\text { del dolor } \\
\text { que tiene } \\
\text { un } \\
\text { deportista } \\
\text { cuando te } \\
\text { obligan a } \\
\text { retirarte, } \\
\text { vivía } \\
\text { recluida. }\end{array}$ & $\begin{array}{l}\text { Al } \\
\text { principio } \\
\text { de hecho } \\
\text { un poco } \\
\text { triste... }\end{array}$ & $\begin{array}{l}\text { Tristeza } \\
\ldots \\
\text { Nostalgi } \\
\text { a }\end{array}$ & $\begin{array}{l}\text { Tristeza, } \\
\text { ansiedad no } \\
\text { tanto, como } \\
\text { aceptando } \\
\text { que ya era } \\
\text { lo que } \\
\text { tocaba. }\end{array}$ & $\begin{array}{l}\text { Me daban } \\
\text { ataques de } \\
\text { pánico, } \\
\text { como una } \\
\text { angustia... } \\
\text { Sentía } \\
\text { mucha } \\
\text { ansiedad... }\end{array}$ & $\begin{array}{l}\text { Un poco de } \\
\text { pena y } \\
\text { nostalgia, } \\
\text { ya que } \\
\text { dejaba una } \\
\text { etapa que } \\
\text { había } \\
\text { significado } \\
\text { mucho para } \\
\text { mí y mi } \\
\text { familia. }\end{array}$ & $\begin{array}{l}\text { Yo estaba } \\
\text { tranquilo, } \\
\text { mis } \\
\text { emociones } \\
\text { no fueron } \\
\text { muy } \\
\text { intensas, las } \\
\text { controlaba. }\end{array}$ \\
\hline & $\begin{array}{l}\text { Pensamie } \\
\text { ntos }\end{array}$ & $\begin{array}{l}\text { Siempre } \\
\text { con la } \\
\text { locura de } \\
\text { que } \\
\text { "ahorita me } \\
\text { llaman para } \\
\text { volver a } \\
\text { jugar"... } \\
\text { ¿Por qué } \\
\text { me retire? }\end{array}$ & & $\begin{array}{l}\text { Me puse a } \\
\text { pensar: de } \\
\text { repente } \\
\text { tengo otras } \\
\text { oportunida } \\
\text { des }\end{array}$ & $\begin{array}{l}\text { No aceptar } \\
\text { que me } \\
\text { tenía que } \\
\text { retirar... } \\
\text { ¿voy a } \\
\text { estar lista } \\
\text { para } \\
\text { Barcelona } \\
92 ? \text { ¿Tú } \\
\text { cree que } \\
\text { voy a estar }\end{array}$ & $\begin{array}{l}\text { Es como } \\
\text { que la } \\
\text { indecisió } \\
\text { n. Que sí } \\
\text { la hago, } \\
\text { que no la } \\
\text { hago, que } \\
\text { sí quiero, } \\
\text { que no } \\
\text { quiero. } \\
\text { Que }\end{array}$ & & $\begin{array}{l}\text { Te tienes } \\
\text { que } \\
\text { conformar, } \\
\text { ya con } \\
\text { tranquilidad } \\
\text { Ya te tocó, } \\
\text { ya pasaste, } \\
\text { ya fuiste. }\end{array}$ & $\begin{array}{l}\text { Es una } \\
\text { incertidumb } \\
\text { re que tú no } \\
\text { sabes cómo } \\
\text { va a ser tu } \\
\text { día de } \\
\text { ahora en } \\
\text { adelante... } \\
\text { Ahora que } \\
\text { viene } \\
\text { después. }\end{array}$ & $\begin{array}{l}\text { Me toca } \\
\text { estudiar } \\
\text { ahora } \\
\text { Es lo que } \\
\text { me toca } \\
\text { ahora. }\end{array}$ & $\begin{array}{l}\text { ¿Con } \\
\text { cuanto } \\
\text { puedo } \\
\text { vivir?... ya } \\
\text { con eso } \\
\text { vivo, tengo } \\
\text { mis } \\
\text { ahorros, } \\
\text { tengo mi } \\
\text { casa, } \\
\text { tranquilo... }\end{array}$ \\
\hline
\end{tabular}




\begin{tabular}{|c|c|c|c|c|c|c|c|c|c|c|c|}
\hline & & & & & $\begin{array}{l}\text { lista para } \\
\text { las } \\
\text { Olimpiada } \\
\text { s?.. } \\
\text { ¿Por qué } \\
\text { yo? ¿Por } \\
\text { qué me } \\
\text { cortaron } \\
\text { esa } \\
\text { posibilidad } \\
?\end{array}$ & $\begin{array}{l}\text { después } \\
\text { voy a } \\
\text { extrañar. }\end{array}$ & & & & & $\begin{array}{l}\text { ¿estoy } \\
\text { preparado } \\
\text { para esto? } \\
\text { Sí }\end{array}$ \\
\hline \multirow{4}{*}{$\begin{array}{l}\text { Impacto del } \\
\text { retiro }\end{array}$} & $\begin{array}{l}\text { Aspecto } \\
\text { personal }\end{array}$ & $\begin{array}{l}\text { Cuando } \\
\text { eres } \\
\text { futbolista te } \\
\text { hacen todo, } \\
\text { te vuelven } \\
\text { muy } \\
\text { inútil... }\end{array}$ & $\begin{array}{l}\text { Me costó } \\
\text { mucho con } \\
\text { los temas } \\
\text { de } \\
\text { ansiedad, } \\
\text { empecé a } \\
\text { comer un } \\
\text { montón, me } \\
\text { engordé un } \\
\text { montón. } \\
\text { Eso me } \\
\text { deprimió... } \\
\text { me volví un } \\
\text { poco } \\
\text { loca... }\end{array}$ & $\begin{array}{l}\text { Yo supe } \\
\text { afrontar las } \\
\text { cosas bien } \\
\text { por mí } \\
\text { misma. A } \\
\text { nivel físico } \\
\text { engordé. } \\
\text { Y a nivel } \\
\text { mental no } \\
\text { podía } \\
\text { desahogar } \\
\text { me, por el } \\
\text { estrés. }\end{array}$ & $\begin{array}{l}\text { Me volví } \\
\text { más } \\
\text { agresiva, } \\
\text { más } \\
\text { contestona, } \\
\text { más } \\
\text { rebelde } \\
\text { hacia la } \\
\text { vida... }\end{array}$ & & $\begin{array}{l}\text { No me } \\
\text { afecto, } \\
\text { no lo } \\
\text { extrañé } \\
\text { porque } \\
\text { siempre } \\
\text { estaba } \\
\text { ligado. }\end{array}$ & $\begin{array}{l}\text { No hubo } \\
\text { impacto a } \\
\text { nivel } \\
\text { personal } \\
\text { porque era } \\
\text { consciente } \\
\text { que era lo } \\
\text { que tocaba. }\end{array}$ & $\begin{array}{l}\text { Me daban } \\
\text { ataques de } \\
\text { pánico. } \\
\text { Me faltaban } \\
\text { cosas que } \\
\text { hacer... no } \\
\text { podía } \\
\text { dormir. Me } \\
\text { tuvieron } \\
\text { que dar una } \\
\text { pastillita... }\end{array}$ & & $\begin{array}{l}\text { Sentí más } \\
\text { tranquilidad } \\
\text {, ya no } \\
\text { estoy en el } \\
\text { ojo de } \\
\text { todos. } \\
\text { Claro que } \\
\text { extrañas }\end{array}$ \\
\hline & $\begin{array}{l}\text { Nivel } \\
\text { social }\end{array}$ & $\begin{array}{l}\text { Después la } \\
\text { gente ya no } \\
\text { te } \\
\text { reconoce... }\end{array}$ & $\begin{array}{l}\text { Empecé a } \\
\text { juerguiar, a } \\
\text { salir los } \\
\text { fines de } \\
\text { semana, a } \\
\text { hacer todo } \\
\text { lo que no } \\
\text { había } \\
\text { hecho. }\end{array}$ & & $\begin{array}{l}\text { Vivía } \\
\text { recluida. }\end{array}$ & $\begin{array}{l}\text { Ya podía } \\
\text { salir un } \\
\text { poco } \\
\text { más... ya } \\
\text { podía } \\
\text { socializar } \\
\text { un poco } \\
\text { más. }\end{array}$ & & $\begin{array}{l}\text { Todo lo que } \\
\text { trae esto es } \\
\text { pena, hay } \\
\text { amigos que } \\
\text { no veo } \\
\text { años... Te } \\
\text { das cuenta } \\
\text { que el actor } \\
\text { ya no eres } \\
\text { tú... }\end{array}$ & & $\begin{array}{l}\text { Creo que } \\
\text { salía más } \\
\text { con mis } \\
\text { amigos... }\end{array}$ & $\begin{array}{l}\text { todo era } \\
\text { Oblitas, yo } \\
\text { ya me había } \\
\text { retirado... } \\
\text { y ese } \\
\text { impacto me } \\
\text { dolió. }\end{array}$ \\
\hline & $\begin{array}{l}\text { Nivel } \\
\text { económic } \\
\text { o }\end{array}$ & $\begin{array}{l}\text { Fue un } \\
\text { golpe } \\
\text { drástico... } \\
\text { el dinero } \\
\text { que ganas } \\
\text { como } \\
\text { futbolista } \\
\text { es fuerte, y } \\
\text { para que lo } \\
\text { vuelvas a } \\
\text { ganar es } \\
\text { difícil... }\end{array}$ & & & $\begin{array}{l}\text { Al } \\
\text { contrario, } \\
\text { se } \\
\text { incrementó } \\
\text {, porque } \\
\text { mi último } \\
\text { contrato... } \\
\text { me sirvió } \\
\text { para poner } \\
\text { mi clínica } \\
\text { y para mis } \\
\text { campañas } \\
\text { políticas }\end{array}$ & $\begin{array}{l}\text { Para bien } \\
\text { porque } \\
\text { como te } \\
\text { digo en el } \\
\text { box no te } \\
\text { pagan... }\end{array}$ & $\begin{array}{l}\text { Disminu } \\
\text { yó en los } \\
\text { primeros } \\
\text { moment } \\
\text { os. Pero } \\
\text { con los } \\
\text { trabajos } \\
\text { que } \\
\text { conseguí } \\
\text { se } \\
\text { revirtió } \\
\text { la } \\
\text { situación } \\
\text {. }\end{array}$ & $\begin{array}{l}\text { Si te afecta } \\
\text { bastante, } \\
\text { pasas de } \\
\text { ganar } \\
\text { regular a } \\
\text { que te } \\
\text { paguen } \\
\text { sueldo } \\
\text { mínimo }\end{array}$ & 7 & & $\begin{array}{l}\text { Ya no } \\
\text { ganaba lo } \\
\text { que ganaba } \\
\text { antes, pero } \\
\text { supe } \\
\text { administrar } \\
\text { bien mi } \\
\text { dinero... }\end{array}$ \\
\hline & $\begin{array}{l}\text { Nivel } \\
\text { familiar }\end{array}$ & & $\begin{array}{l}\text { Para mis } \\
\text { papás fue } \\
\text { una } \\
\text { inversión } \\
\text { de tiempo y } \\
\text { de plata... } \\
\text { y una de las } \\
\text { cosas más } \\
\text { difíciles } \\
\text { que me } \\
\text { pasó fue } \\
\text { que mi } \\
\text { papá me } \\
\text { dejó de } \\
\text { hablar por } \\
\text { mucho } \\
\text { tiempo } \\
\text { cuando yo } \\
\text { me retiré, }\end{array}$ & & $\begin{array}{l}\text { A ellos les } \\
\text { afecto, } \\
\text { porque } \\
\text { gracias a } \\
\text { que yo } \\
\text { vivía fuera } \\
\text { mi mamá } \\
\text { conoció } \\
\text { Europa, } \\
\text { mis } \\
\text { hermanos } \\
\text { recibían un } \\
\text { regalo, yo } \\
\text { no tenía } \\
\text { hijos, } \\
\text { entonces } \\
\text { Cecilia era } \\
\text { cajero } \\
\text { automático } \\
\text { sin tarjeta. }\end{array}$ & $\begin{array}{l}\text { De hecho } \\
\text { les dio un } \\
\text { poco más } \\
\text { de calma, } \\
\text { porque } \\
\text { como es } \\
\text { un } \\
\text { deporte } \\
\text { con } \\
\text { riesgo } \\
\text { estaban } \\
\text { un poco } \\
\text { más } \\
\text { felices de } \\
\text { que ya no } \\
\text { corres el } \\
\text { riesgo. }\end{array}$ & $\begin{array}{l}\text { Yo creo } \\
\text { que tuve } \\
\text { un } \\
\text { acercami } \\
\text { ento } \\
\text { mayor a } \\
\text { la } \\
\text { familia, } \\
\text { porque } \\
\text { cuando } \\
\text { yo era } \\
\text { boxeado } \\
\text { r viajaba } \\
\text { mucho } \\
\text { por las } \\
\text { peleas. }\end{array}$ & A & $\begin{array}{l}\text { Fue mejor, } \\
\text { porque } \\
\text { tenía más } \\
\text { tiempo de } \\
\text { estar con } \\
\text { mis hijos. }\end{array}$ & & $\begin{array}{l}\text { Tuve más } \\
\text { tiempo con } \\
\text { la familia } \\
\text { nuclear. } \\
\text { Con mis } \\
\text { hijas hay } \\
\text { más } \\
\text { contacto. }\end{array}$ \\
\hline
\end{tabular}




\begin{tabular}{|c|c|c|c|c|c|c|c|c|c|c|c|}
\hline & & & $\begin{array}{l}\text { se molestó } \\
\text { horrible... }\end{array}$ & & $\begin{array}{l}\text { Creo que sí } \\
\text { les afectó y } \\
\text { se } \\
\text { molestaron }\end{array}$ & & & & & & \\
\hline \multirow[t]{2}{*}{$\begin{array}{l}\text { Determinan } \\
\text { tes que } \\
\text { condiciona } \\
\mathrm{n} \text { la } \\
\text { adaptación }\end{array}$} & $\begin{array}{l}\text { Recursos } \\
\text { individua } \\
\text { les }\end{array}$ & $\begin{array}{l}\text { Mi carácter, } \\
\text { mi } \\
\text { personalida } \\
\text { d, ser muy } \\
\text { disciplinad } \\
\text { o me } \\
\text { ayudó... } \\
\text { siempre mi } \\
\text { intención } \\
\text { fue ser } \\
\text { entrenador } \\
\text { de futbol... } \\
\text { No pude } \\
\text { tener } \\
\text { cambios } \\
\text { emocionale } \\
\text { s porque } \\
\text { cuando } \\
\text { terminé } \\
\text { tenía } \\
\text { estas... } \\
\text { actividades, } \\
\text { entonces mi } \\
\text { cabeza } \\
\text { estaba en } \\
\text { otra... }\end{array}$ & $\begin{array}{l}\text { La ansiedad } \\
\text { la he } \\
\text { canalizado } \\
\text { en otras } \\
\text { cosas, en } \\
\text { cuidarme, } \\
\text { hacer } \\
\text { ejercicios } \\
\text { para } \\
\text { sentirme } \\
\text { bien } \\
\text { conmigo } \\
\text { misma... } \\
\text { Yo no lo } \\
\text { planifiqué } \\
\text { no tenía ni } \\
\text { idea de lo } \\
\text { que iba a } \\
\text { hacer... } \\
\text { Empecé a } \\
\text { trabajar } \\
\text { como } \\
\text { entrenadora } \\
\text {... }\end{array}$ & & $\begin{array}{l}\text { Soy una } \\
\text { persona } \\
\text { resiliente } \\
\text {... Soy } \\
\text { muy } \\
\text { ambiciosa } \\
\text { en las } \\
\text { cosas que } \\
\text { quiero... } \\
\text { mi forma } \\
\text { de ser, mi } \\
\text { actitud, } \\
\text { soy muy } \\
\text { renegona y } \\
\text { no me } \\
\text { gusta ser } \\
\text { pobre... } \\
\text { soy } \\
\text { perseveran } \\
\text { te, } \\
\text { disciplinad } \\
\text { a.... } \\
\text { Me } \\
\text { enseñaron } \\
\text { a guardar } \\
\text { pan para } \\
\text { mayo... } \\
\text { invertí... } \\
\text { Me } \\
\text { dediqué a } \\
\text { hacer mil } \\
\text { cosas... }\end{array}$ & $\begin{array}{l}\text { Soy bien } \\
\text { adaptable } \\
\text {, soy } \\
\text { relajado } \\
\text {.. no soy } \\
\text { trágico... } \\
\text { siempre } \\
\text { me } \\
\text { manejo } \\
\text { como que } \\
\text { Dios } \\
\text { proveerá, } \\
\text { por algo } \\
\text { pasan las } \\
\text { cosas.... } \\
\text { Las } \\
\text { tantas } \\
\text { horas que } \\
\text { se las } \\
\text { dedicaba } \\
\text { a box ya } \\
\text { se las } \\
\text { dediqué } \\
\text { al jiu- } \\
\text { jitsu... }\end{array}$ & $\begin{array}{l}\text { Ya había } \\
\text { hecho } \\
\text { mi } \\
\text { carrera } \\
\text { de } \\
\text { marketin } \\
\text { g, mi } \\
\text { primera } \\
\text { carrera } \\
\text { de } \\
\text { entrenad } \\
\text { or de } \\
\text { boxeo... } \\
\text { menos } \\
\text { mal que } \\
\text { había } \\
\text { aprendid } \\
\text { o este } \\
\text { estudio y } \\
\text { me iba } \\
\text { tranquilo } \\
\text { a } \\
\text { trabajar. }\end{array}$ & & $\begin{array}{l}\text { Mi carácter } \\
\text { bromista } \\
\text { jovial, } \\
\text { alegre... es } \\
\text { como que } \\
\text { hay que } \\
\text { hacer } \\
\text { algunas } \\
\text { cosas } \\
\text { diferentes y } \\
\text { yo las } \\
\text { hago.... Me } \\
\text { dedicaba } \\
\text { más al } \\
\text { trabajo. Me } \\
\text { metí al } \\
\text { gimnasio, } \\
\text { me puse a } \\
\text { pintar, algo } \\
\text { que me } \\
\text { relajaba }\end{array}$ & $\begin{array}{l}\text { Sí } \\
\text { planifiqué } \\
\text { mi retiro, } \\
\text { sabía } \\
\text { perfectame } \\
\text { nte lo que } \\
\text { quería } \\
\text { hacer... En } \\
\text { ese } \\
\text { momento } \\
\text { me tocaba } \\
\text { estudiar, no } \\
\text { podía } \\
\text { seguir } \\
\text { nadando y } \\
\text { estudiando } \\
\text { al mismo } \\
\text { tiempo... } \\
\text { empalmé } \\
\text { con mi vida } \\
\text { universitari } \\
\text { a, no me } \\
\text { dio tanto } \\
\text { tiempo de } \\
\text { sentir } \\
\text { tristeza. } \\
\end{array}$ & $\begin{array}{l}\text { Yo estaba } \\
\text { preparado } \\
\text { para eso } \\
\text { porque } \\
\text { había } \\
\text { estudiado... } \\
\text { Yo ya tenía } \\
\text { en mente } \\
\text { que cuando } \\
\text { me retirara } \\
\text { enseñar a } \\
\text { los niños.... } \\
\text { Tengo mis } \\
\text { inversiones, } \\
\text { yo no gané } \\
\text { demasiado } \\
\text { dinero, pero } \\
\text { sí lo invertí } \\
\text { bien, } \\
\text { entonces } \\
\text { tenía una } \\
\text { estabilidad. }\end{array}$ \\
\hline & $\begin{array}{l}\text { Recursos } \\
\text { sociales }\end{array}$ & & $\begin{array}{l}\text { Si mi papá } \\
\text { se lo } \\
\text { hubiera } \\
\text { tomado de } \\
\text { diferente } \\
\text { manera... } \\
\text { mi papá me } \\
\text { dejó de } \\
\text { hablar, se } \\
\text { peleó } \\
\text { conmigo... } \\
\text { No tuve } \\
\text { psicólogo } \\
\text {... como } \\
\text { me hubiera } \\
\text { gustado } \\
\text { retirarme y } \\
\text { tener algún } \\
\text { apoyo... }\end{array}$ & $\begin{array}{l}\text { Mi } \\
\text { mamá... } \\
\text { me dejo de } \\
\text { hablar de } \\
\text { natación } \\
\text { para } \\
\text { ayudarme } \\
\text { a salir } \\
\text { adelante... } \\
\text { Mi grupo } \\
\text { de amigos } \\
\text { fue mi } \\
\text { apoyo... }\end{array}$ & $\begin{array}{l}\text { No tuve, } \\
\text { pero sí } \\
\text { considero } \\
\text { que } \\
\text { hubiera } \\
\text { sido } \\
\text { necesario, } \\
\text { todo } \\
\text { hubiera } \\
\text { sido } \\
\text { mucho } \\
\text { más fácil. }\end{array}$ & & & $\begin{array}{l}\text { Con un } \\
\text { grupo de } \\
\text { amigos, } \\
\text { compañeros } \\
\text {... que } \\
\text { también } \\
\text { estaban en } \\
\text { la misma } \\
\text { situación y } \\
\text { nos } \\
\text { arreglamos } \\
\text { con la peña } \\
\text { de los } \\
\text { jueves... } \\
\text { Tenía la } \\
\text { acogida de } \\
\text { los } \\
\text { hinchas... }\end{array}$ & $\begin{array}{l}\text { Nunca tuve } \\
\text { apoyo } \\
\text { psicológico } \\
\text {. Yo creo } \\
\text { que es } \\
\text { necesario } \\
\text { incluso } \\
\text { antes de } \\
\text { pensar en } \\
\text { retirarte, y } \\
\text { así todo se } \\
\text { vuelve un } \\
\text { proceso. }\end{array}$ & 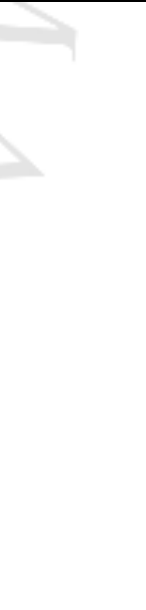 & \\
\hline $\begin{array}{l}\text { Satisfacció } \\
\text { n con su } \\
\text { vida en la } \\
\text { actualidad }\end{array}$ & Alta & $\begin{array}{l}\text { Sí me sentí } \\
\text { satisfecho, } \\
\text { sobre todo } \\
\text { con la } \\
\text { academia. } \\
\text { Ayudar a } \\
\text { los niños a } \\
\text { alcanzar } \\
\text { sus sueños, } \\
\text { los ayudas } \\
\text { en su } \\
\text { desarrollo } \\
\text { como }\end{array}$ & $\begin{array}{l}\text { De hecho, } \\
\text { ahorita } \\
\text { siento } \\
\text { satisfacción } \\
\text { personal... } \\
\text { tengo una } \\
\text { familia, } \\
\text { estoy } \\
\text { planeando } \\
\text { tener un } \\
\text { hijo, soy tía } \\
\text { de } 3 \\
\text { sobrinos } \\
\text { hermosos... }\end{array}$ & $\begin{array}{l}\text { Llegué a } \\
\text { lograr lo } \\
\text { que } \\
\text { quería... } \\
\text { con mi } \\
\text { trabajo fue } \\
\text { igual... En } \\
\text { relación de } \\
\text { pareja y } \\
\text { familia yo } \\
\text { creo que } \\
\text { también... }\end{array}$ & $\begin{array}{l}\text { Yo tuve } \\
\text { dos hijas } \\
\text { maravillos } \\
\text { as. Tuve } \\
\text { esposos } \\
\text { maravillos } \\
\text { os. Tuve } \\
\text { mil cosas } \\
\text { para hacer } \\
\text { y ayudar. } \\
\text { Y en todas } \\
\text { las etapas } \\
\text { no ha sido } \\
\text { fácil, pero }\end{array}$ & $\begin{array}{l}\text { Sí me } \\
\text { sentí } \\
\text { satisfech } \\
\text { o porque } \\
\text { estaba } \\
\text { relaciona } \\
\text { do con lo } \\
\text { que yo } \\
\text { hacía... }\end{array}$ & $\begin{array}{l}\text { Ahora } \\
\text { me } \\
\text { siento un } \\
\text { hombre } \\
\text { logrado } \\
\ldots\end{array}$ & $\begin{array}{l}\text { Sí, en } \\
\text { todos. Uno } \\
\text { por mis } \\
\text { sobrinos } \\
\text { porque } \\
\text { todos están } \\
\text { bien } \\
\text { encaminado } \\
\text { s, están a } \\
\text { un paso de } \\
\text { ser } \\
\text { profesional } \\
\text { es, mi }\end{array}$ & $\begin{array}{l}\text { Satisfacció } \\
\mathrm{n} \text { en el } \\
\text { sentido de } \\
\text { que tengo } \\
\text { más tiempo } \\
\text { de estar con } \\
\text { mis hijos y } \\
\text { de que los } \\
\text { he podido } \\
\text { criar. }\end{array}$ & $\begin{array}{l}\text { Mucha } \\
\text { satisfacción } \\
\text {. Sobre } \\
\text { todo, que } \\
\text { me casé y } \\
\text { comencé a } \\
\text { formar mi } \\
\text { familia. }\end{array}$ & $\begin{array}{l}\text { Sí, como te } \\
\text { digo el } \\
\text { hecho que } \\
\text { la gente } \\
\text { todavía nos } \\
\text { recuerde, } \\
\text { todavía me } \\
\text { inviten a } \\
\text { participar } \\
\text { en } \\
\text { diferentes } \\
\text { actividades } \\
\text {... siento } \\
\text { que deje }\end{array}$ \\
\hline
\end{tabular}




\begin{tabular}{|c|c|c|c|c|c|c|}
\hline & $\begin{array}{l}\text { personas, y } \\
\text { eso te llena. }\end{array}$ & & $\begin{array}{l}\text { me } \\
\text { levanto... }\end{array}$ & & $\begin{array}{l}\text { madre está } \\
\text { feliz... }\end{array}$ & $\begin{array}{l}\text { una } \\
\text { huella.. }\end{array}$ \\
\hline Baja & $\begin{array}{l}\text { Sí... pero } \\
\text { nunca va a } \\
\text { ser lo } \\
\text { mismo, } \\
\text { vivir una } \\
\text { vida de alto } \\
\text { rendimiento } \\
\text { en } \\
\text { competenci } \\
\text { a en } \\
\text { deporte. } \\
\text { Para mí hay } \\
\text { gene que sí } \\
\text { le encanta y } \\
\text { le aloca } \\
\text { estudiar, } \\
\text { para mí no. } \\
\text { Lo hago } \\
\text { porque lo } \\
\text { tengo que } \\
\text { hacer. }\end{array}$ & $\begin{array}{l}\text { El trabajo } \\
\text { no fue el } \\
\text { amor de mi } \\
\text { vida como } \\
\text { lo fue la } \\
\text { natación, } \\
\text { pero por lo } \\
\text { menos } \\
\text { sentía que } \\
\text { hacía algo } \\
\text { adicional. }\end{array}$ & & $\begin{array}{l}\text { No me } \\
\text { sentí del } \\
\text { todo } \\
\text { satisfech } \\
\text { o, } \\
\text { siempre } \\
\text { me } \\
\text { faltaba } \\
\text { algo. }\end{array}$ & & \\
\hline
\end{tabular}

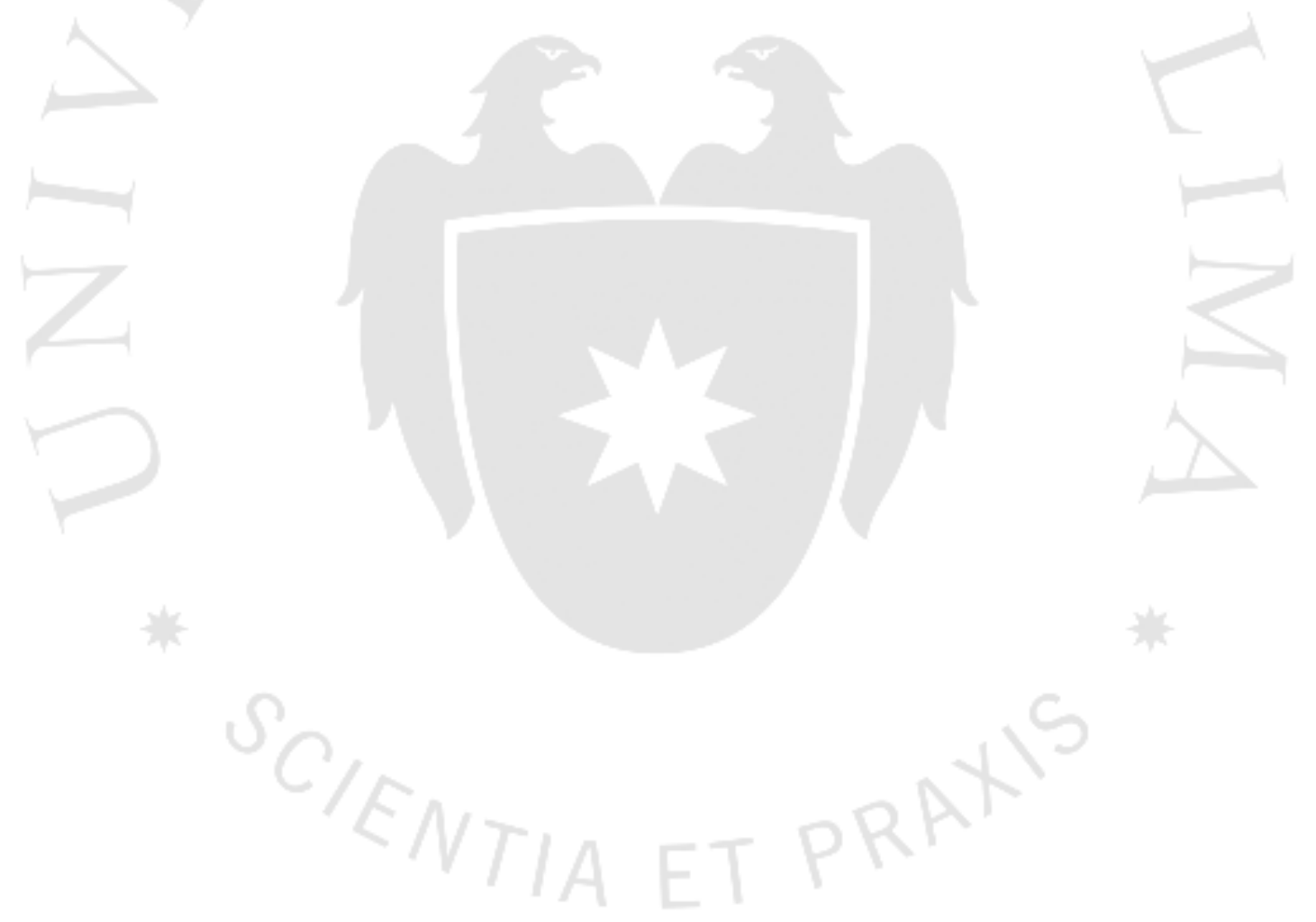

